Portland State University

PDXScholar

\title{
Assessing State Efforts to Integrate Transportation, Land Use and Climate
}

\author{
Rebecca Lewis \\ University of Oregon \\ Robert Zako \\ University of Oregon
}

Follow this and additional works at: https://pdxscholar.library.pdx.edu/trec_reports

Part of the Transportation Commons, Urban Studies Commons, and the Urban Studies and Planning Commons

Let us know how access to this document benefits you.

\section{Recommended Citation}

Lewis, R., and Zako, R. Assessing State Efforts to Integrate Transportation, Land Use and Climate. NITCRR-789. Portland, OR: Transportation Research and Education Center (TREC), 2017. http://dx.doi.org/ 10.15760/trec.162

This Report is brought to you for free and open access. It has been accepted for inclusion in TREC Final Reports by an authorized administrator of PDXScholar. Please contact us if we can make this document more accessible: pdxscholar@pdx.edu. 


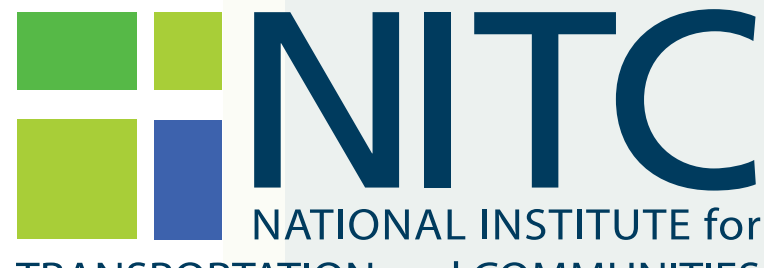

TRANSPORTATION and COMMUNITIES

FINAL REPORT

\section{Assessing State Efforts to Integrate Transportation, Land Use and Climate Change}

NITC-RR-789 $\quad$ January 2017

NITC is the U.S. Department of Transportation's national university transportation center for livable communities.

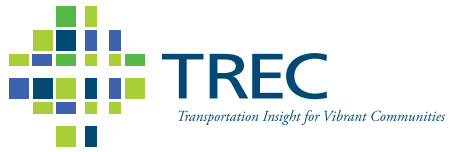





\title{
ASSESSING STATE EFFORTS TO INTEGRATE TRANSPORTATION, LAND USE AND CLIMATE CHANGE
}

\author{
Final Report \\ NITC-RR-789 \\ by \\ Rebecca Lewis \\ Robert Zako \\ University of Oregon
}

for

National Institute for Transportation and Communities (NITC)

P.O. Box 751

Portland, OR 97207

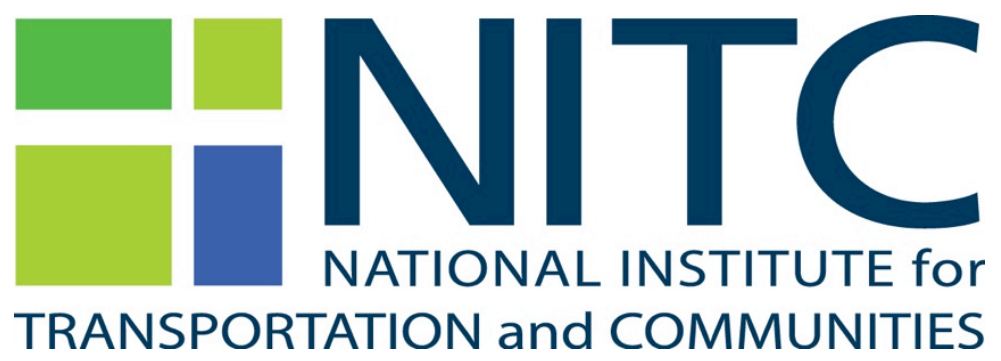

January 2017 



\begin{tabular}{|c|c|c|c|c|}
\hline \multicolumn{5}{|c|}{ Technical Report Documentation Page } \\
\hline $\begin{array}{l}\text { 1. Report No. } \\
\text { NITC-RR-789 }\end{array}$ & \multicolumn{2}{|c|}{ 2. Government Accession No. } & \multicolumn{2}{|c|}{ 3. Recipient’s Catalog No. } \\
\hline \multirow{2}{*}{\multicolumn{4}{|c|}{$\begin{array}{l}\text { 4. Title and Subtitle } \\
\text { Assessing State Efforts to Integrate Transportation, Land Use and Climate Change }\end{array}$}} & \\
\hline & & & & 6. Performing Organization Code \\
\hline \multicolumn{3}{|l|}{$\begin{array}{l}\text { 7. Author(s) } \\
\text { Rebecca Lewis } \\
\text { Robert Zako }\end{array}$} & \multicolumn{2}{|c|}{ 8. Performing Organization Report No. } \\
\hline \multirow{2}{*}{\multicolumn{4}{|c|}{$\begin{array}{l}\text { 9. Performing Organization Name and Address } \\
\text { Rebecca Lewis } \\
\text { 1209 University of Oregon } \\
\text { Eugene, OR 97403-1209 }\end{array}$}} & 10. Work Unit No. (TRAIS) \\
\hline & & & $\begin{array}{l}\text { 11. Cont } \\
\text { NITC }\end{array}$ & 11. Contract or Grant No. \\
\hline \multicolumn{3}{|c|}{$\begin{array}{l}\text { 12. Sponsoring Agency Name and Address } \\
\text { National Institute for Transportation and Communities (NITC) } \\
\text { P.O. Box } 751 \\
\text { Portland, Oregon } 97207\end{array}$} & $\begin{array}{r}\text { 13. Type } \\
\text { Final } \\
\text { Augu } \\
\text { 14. Spon }\end{array}$ & $\begin{array}{l}\text { eriod Covered } \\
16 \\
\text { ode }\end{array}$ \\
\hline \multicolumn{5}{|l|}{ 15. Supplementary Notes } \\
\hline \multicolumn{5}{|c|}{$\begin{array}{l}\text { Climate change is increasingly recognized as a threat to life on earth. "Continued emission of greenhouse gases will cause further } \\
\text { warming and long-lasting changes in all components of the climate system, increasing the likelihood of severe, pervasive and irreversible } \\
\text { impacts for people and ecosystems. Limiting climate change would require substantial and sustained reductions in greenhouse gas emissions" } \\
\text { (International Panel on Climate Change, 2014, 8). } \\
\text { The transportation sector accounts for almost one-third of all greenhouse gas emissions (GHG) in the United States. Reducing GHG from } \\
\text { transportation rests on the "three-legged stool” of improving vehicle efficiency, reducing the carbon content of fuels and reducing vehicle } \\
\text { miles traveled (VMT). But "technological improvements in vehicles and fuels are likely to be offset by continuing, robust growth in VMT" } \\
\text { (Ewing et al., 2007, 2). Thus, a crucial strategy in curbing GHG from transportation relies on reducing total VMT by promoting alternative } \\
\text { modes of transportation hand in hand with promoting development patterns that support the use of such modes, in addition to pricing strategies } \\
\text { (for GHG, parking, gas taxes, tolls, etc.) and lifestyle changes to shift from driving. In developing climate action plans, states have begun to } \\
\text { acknowledge the connection between transportation and development patterns. } \\
\text { This project explores the institutional barriers and opportunities for reducing VMT, hence GHG, through improved transportation options } \\
\text { and smarter development patterns in four states: California, Maryland, Oregon and Washington. The research team analyzed existing policy } \\
\text { frameworks around transportation, land use and climate change, outlining the statutory context around plans and actions within state agencies } \\
\text { and metropolitan planning organizations (MPOs). The research team used content analysis to analyze existing plans under these agencies, and } \\
\text { conducted interviews with over } 40 \text { stakeholders to evaluate strengths and weaknesses of state approaches. The research team assessed the } \\
\text { existing policy framework within the case study states and offers recommendations for improving existing frameworks. Finally, lessons learned } \\
\text { from these four states can inform other states attempting to reduce GHG from transportation. }\end{array}$} \\
\hline \multicolumn{2}{|c|}{$\begin{array}{l}\text { 17. Key Words } \\
\text { climate change, greenhouse gases, state departments of transportation, } \\
\text { metropolitan planning organizations, transportation planning }\end{array}$} & \multicolumn{3}{|c|}{$\begin{array}{l}\text { 18. Distribution Statement } \\
\text { No restrictions. Copies available from } \\
\text { NITC: www.nitc-utc.net }\end{array}$} \\
\hline $\begin{array}{l}\text { 19. Security Classification (of this report) } \\
\text { Unclassified }\end{array}$ & $\begin{array}{l}\text { 20. Security Classificat } \\
\text { Unclassified }\end{array}$ & page) & $\begin{array}{l}\text { 21. No. of Pages } \\
92\end{array}$ & 22. Price \\
\hline
\end{tabular}





\section{ACKNOWLEDGEMENTS}

This research was funded in part by the National Institute for Transportation and Communities (NITC), a program of the Transportation Research and Education Center at Portland State University and a U.S. Department of Transportation university transportation center. This research also received funding from the University of Oregon Faculty Research Award Program.

The authors would like to thank Alexis Biddle, Rory Isbell, Emily Kettell and Elizabeth Miller for research assistance.

The team gratefully acknowledges stakeholders who volunteered their time to be interviewed and review drafts.

\section{DISCLAIMER}

The contents of this report reflect the views of the authors, who are solely responsible for the facts and the accuracy of the material and information presented herein. This document is disseminated under the sponsorship of the U.S. Department of Transportation University Transportation Centers Program in the interest of information exchange. The U.S. Government assumes no liability for the contents or use thereof. The contents do not necessarily reflect the official views of the U.S. Government. This report does not constitute a standard, specification, or regulation. 



\section{TABLE OF CONTENTS}

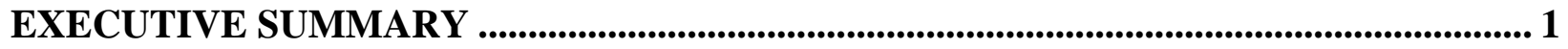

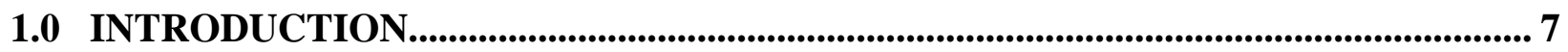

2.0 LITERATURE REVIEW ................................................................................................... 11

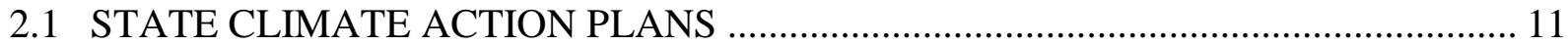

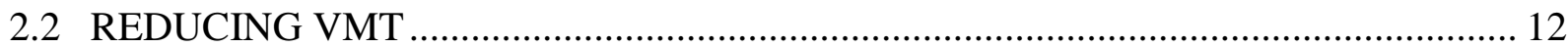

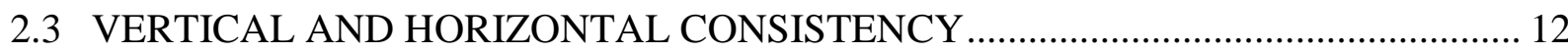

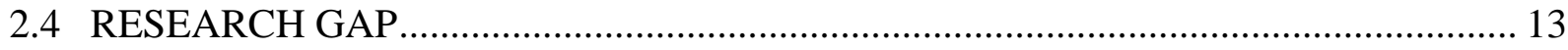

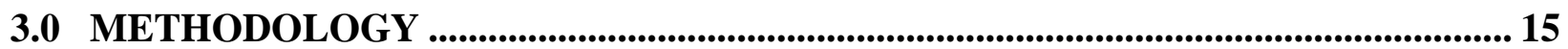

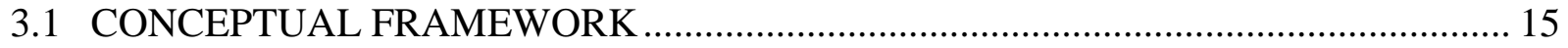

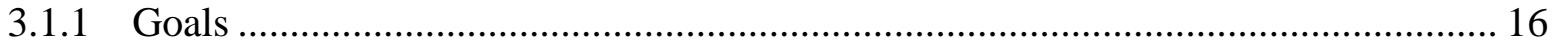

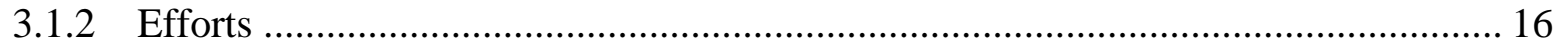

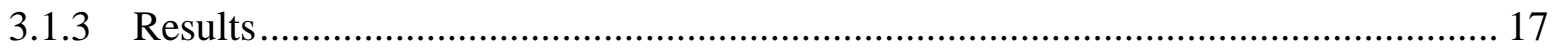

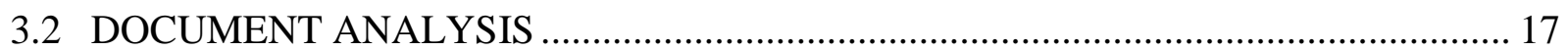

3.3 STAKEHOLDER INTERVIEWS ………………................................................. 17

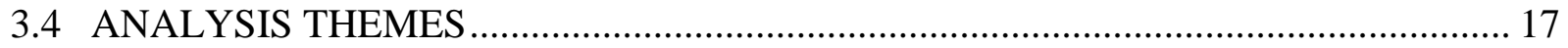

4.0 CASE STUDY STATES ..................................................................................... 19

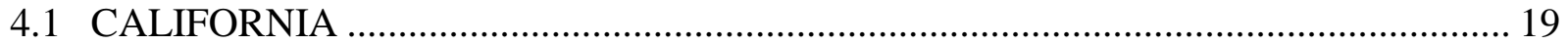

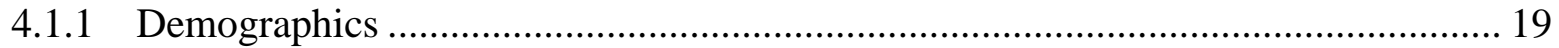

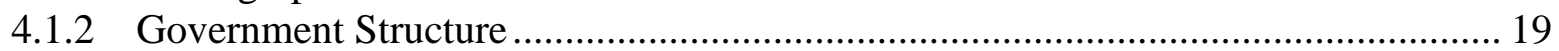

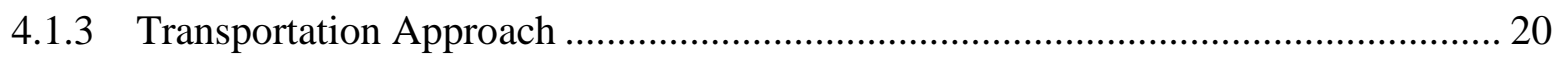

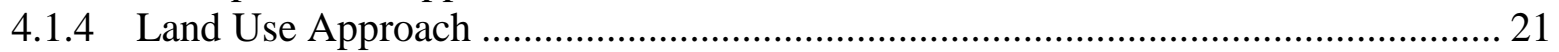

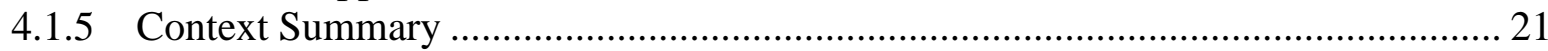

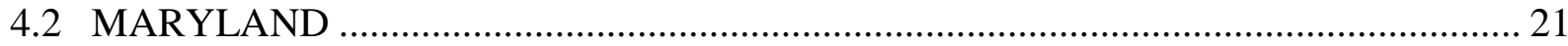

4.2.1 Demographics …………………………………………………………... 22

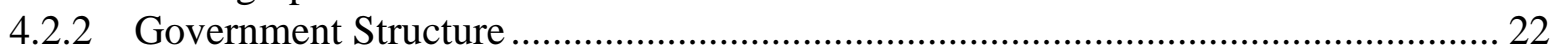

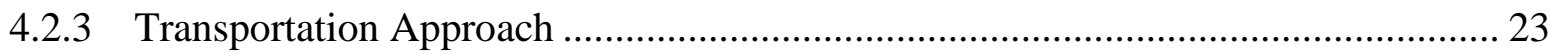

4.2.4 Land Use Approach ............................................................................................ 23

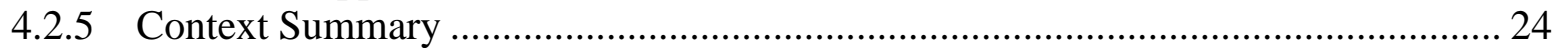

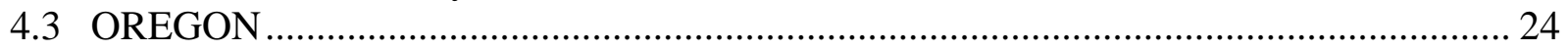

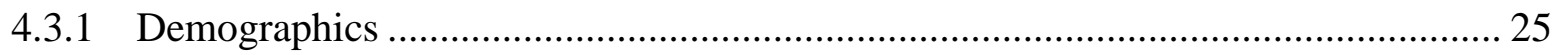

4.3.2 Government Structure ................................................................................. 25

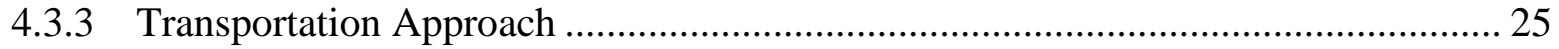

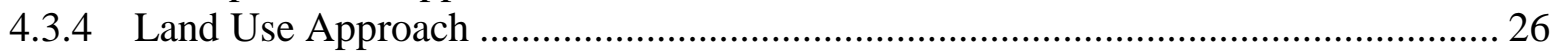

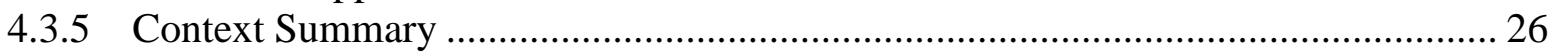

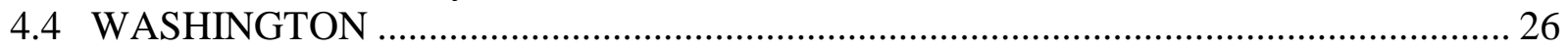

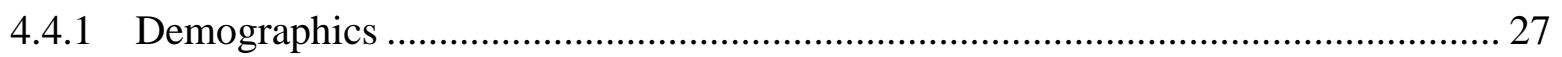

4.4.2 Government Structure .......................................................................................... 27

4.4.3 Transportation Approach ....................................................................................... 27

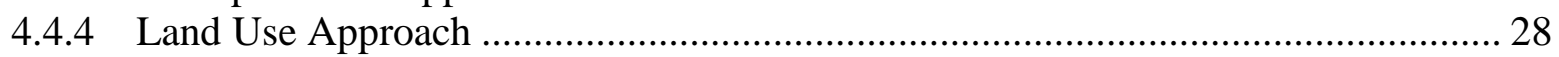

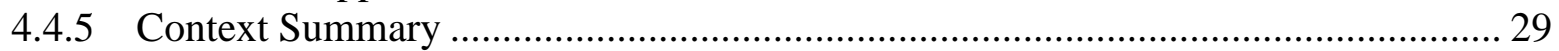

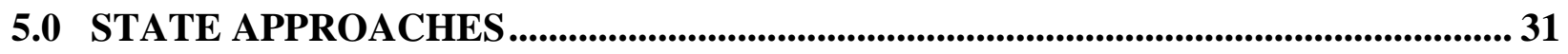

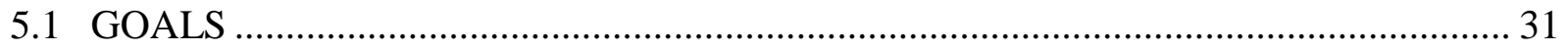

5.1.1 California ................................................................................................................ 33 


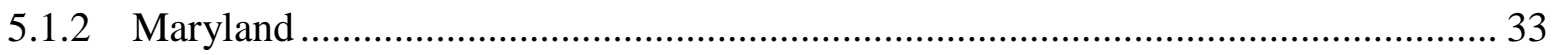

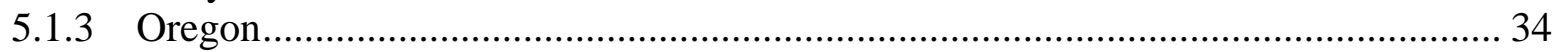

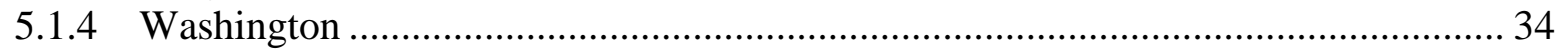

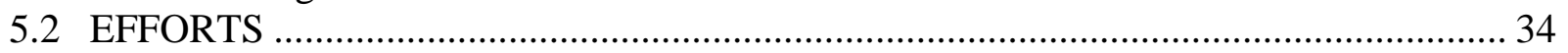

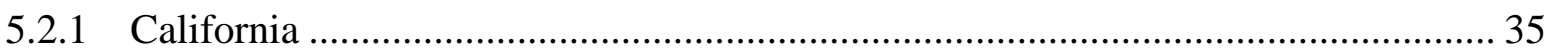

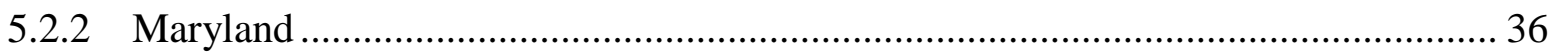

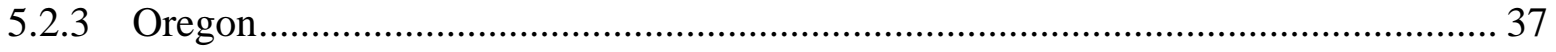

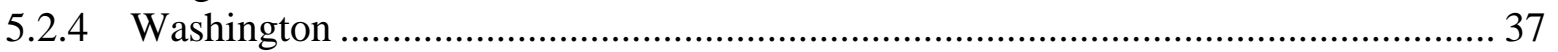

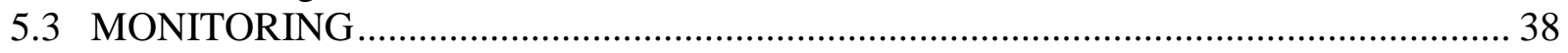

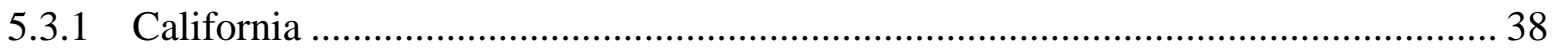

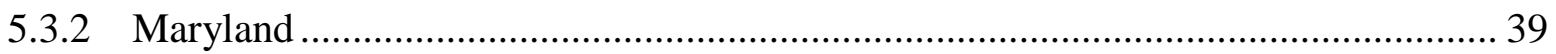

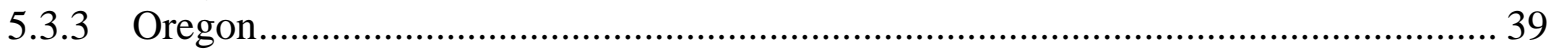

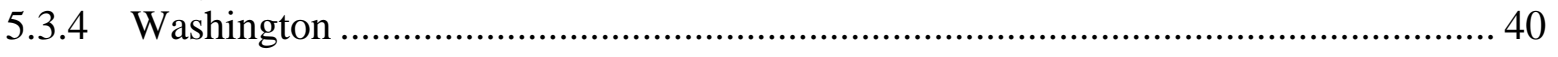

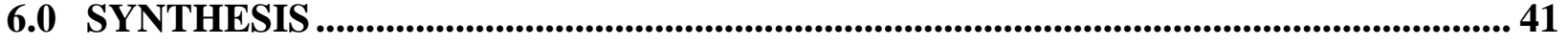

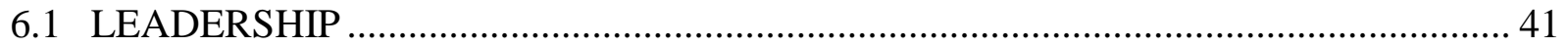

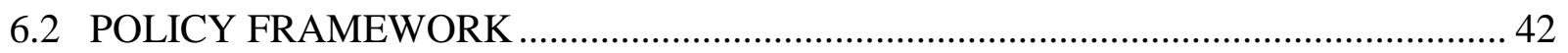

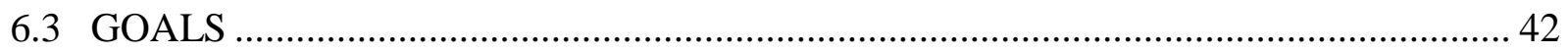

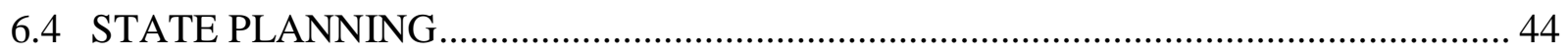

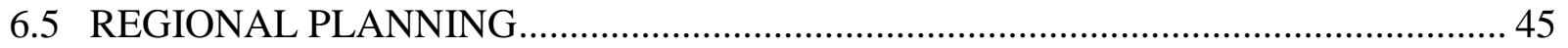

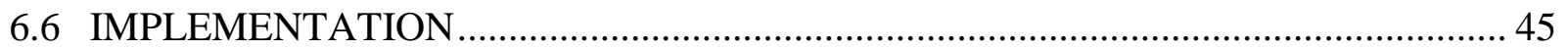

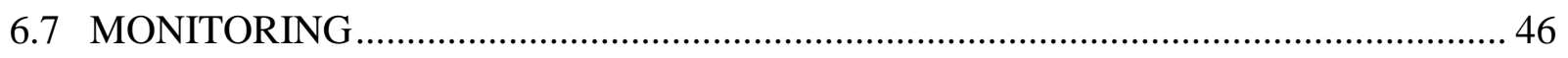

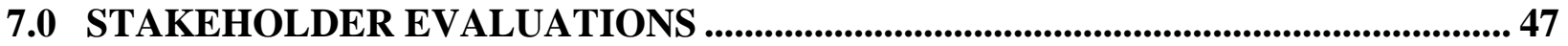

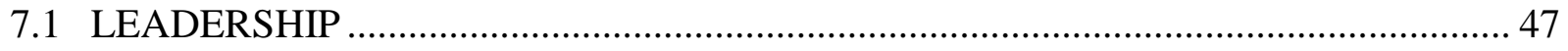

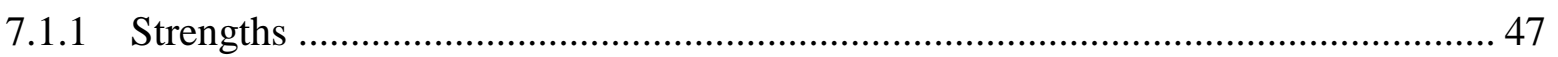

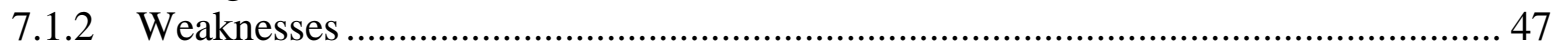

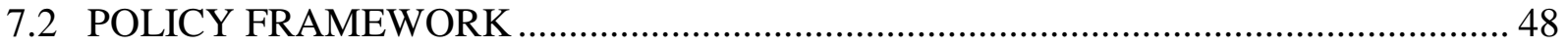

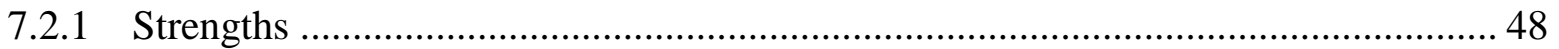

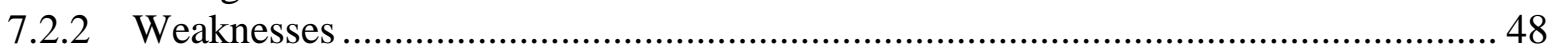

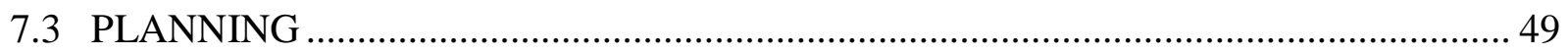

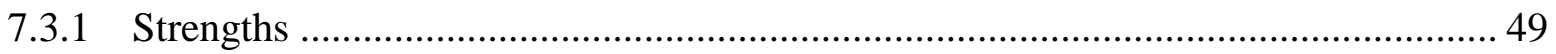

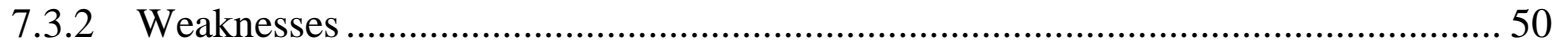

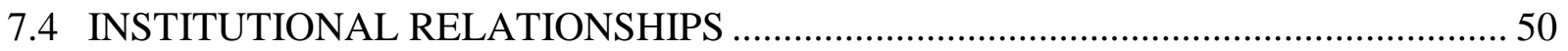

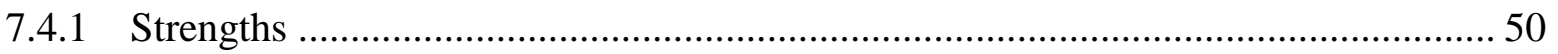

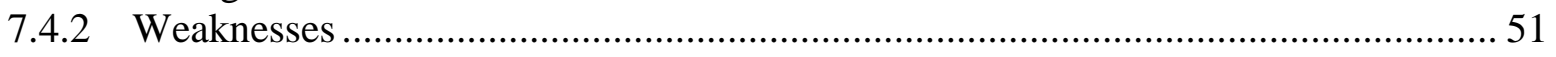

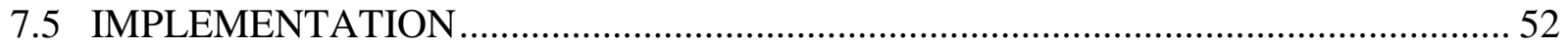

7.5.1 Strengths …………………………………............................................... 52

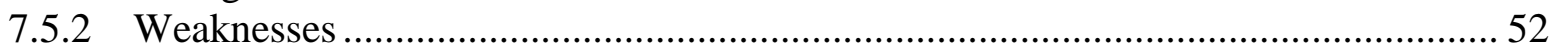

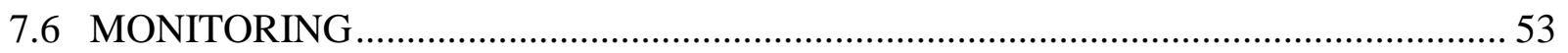

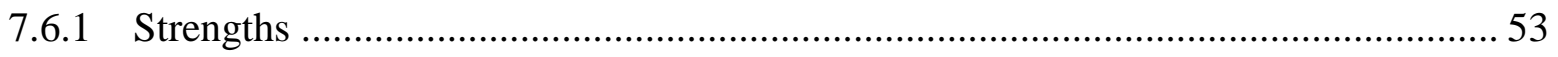

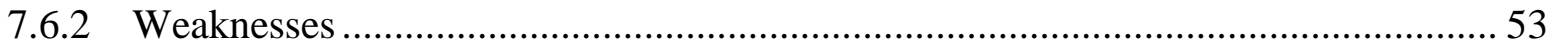

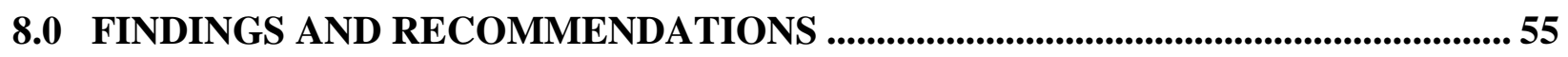

8.1 LEADERSHIP …………………………………………………………….... 56

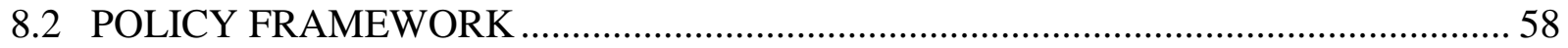

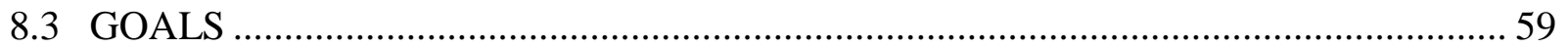

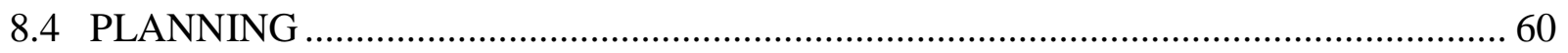

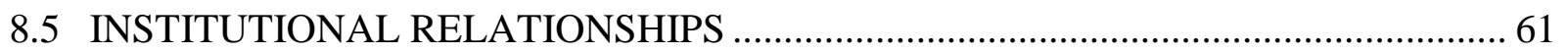




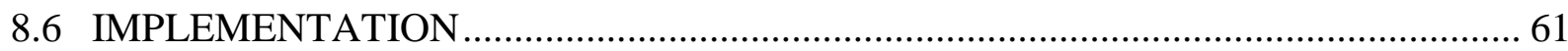

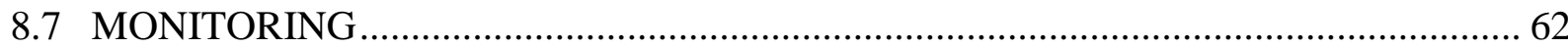

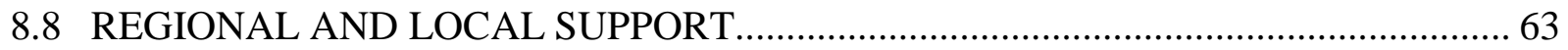

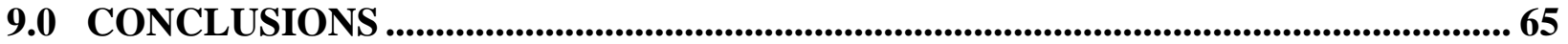

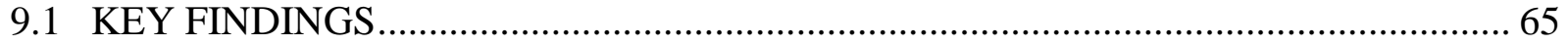

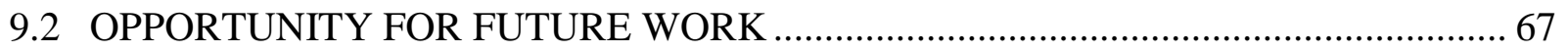

10.0 REFERENCES.........................................................................................................................6 69

APPENDIX A: SAMPLE INTERVIEW GUIDE .............................................................. A-1

APPENDIX B: LIST OF STAKEHOLDERS INTERVIEWED.......................................... B-1

\section{LIST OF TABLES}

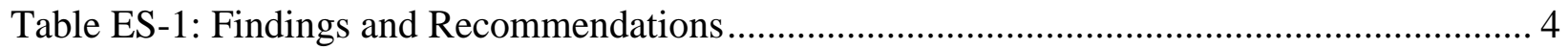

Table 1.1: 2010 Greenhouse Gas Emissions.......................................................................... 7

Table 5.1: Policy Choices in Setting GHG Reduction Targets for Light-Duty Vehicles ............. 32

Table 5.2: Statewide GHG Goals and Light-Duty Vehicle Targets ......................................... 33

Table 6.1: Leadership, Policy Framework and Goals by State ............................................... 41

Table 6.2: Planning, Implementation and Monitoring by State ............................................. 43

Table 7.1: Leadership Strengths and Weaknesses ............................................................ 47

Table 7.2: Policy Framework Strengths and Weaknesses ..................................................... 48

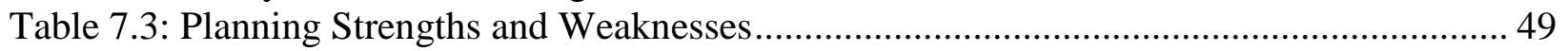

Table 7.4: Institutional Relationships Strengths and Weaknesses......................................... 50

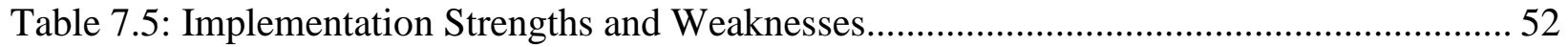

Table 7.6: Monitoring Strengths and Weaknesses.............................................................. 53

Table 8.1: Leadership Findings and Recommendations ..................................................... 56

Table 8.2: Policy Framework Findings and Recommendations .............................................. 58

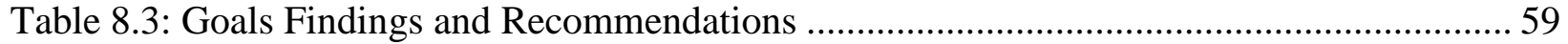

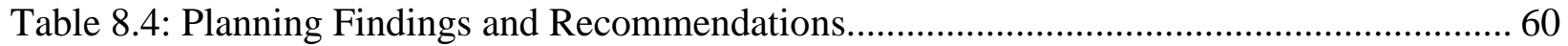

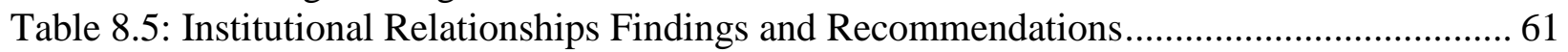

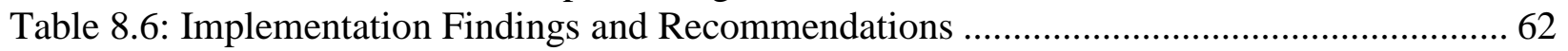

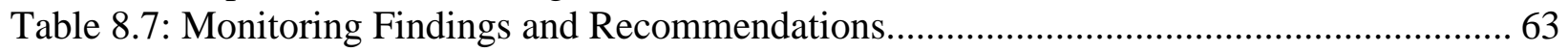

Table 8.8: Regional and Local Support Findings and Recommendations................................ 63

\section{LIST OF FIGURES}

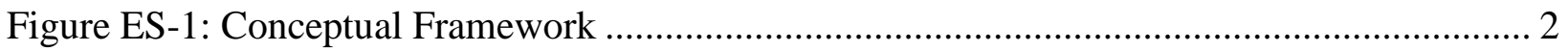

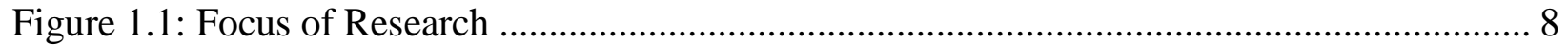

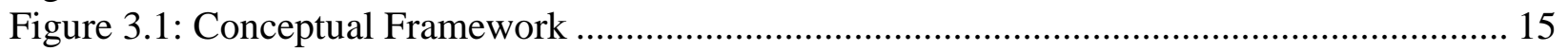

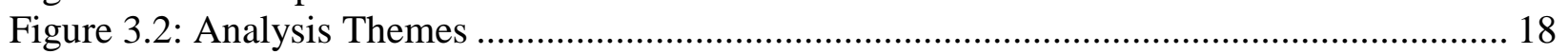

Figure 8.1: The Five-Step Management by Objectives Process ............................................... 58 



\section{EXECUTIVE SUMMARY}

\section{Background}

Climate change is increasingly recognized as a threat to life on earth. "Continued emission of greenhouse gases will cause further warming and long-lasting changes in all components of the climate system, increasing the likelihood of severe, pervasive and irreversible impacts for people and ecosystems. Limiting climate change would require substantial and sustained reductions in greenhouse gas emissions” (International Panel on Climate Change, 2014, 8).

The transportation sector accounts for almost one-third of all greenhouse gas emissions (GHG) in the United States. Reducing GHG from transportation rests on the "three-legged stool" of improving vehicle efficiency, reducing the carbon content of fuels and reducing vehicle miles traveled (VMT). But "technological improvements in vehicles and fuels are likely to be offset by continuing, robust growth in VMT” (Ewing et al., 2007, 2). Thus, a crucial strategy in curbing GHG from transportation relies on reducing total VMT by promoting alternative modes of transportation hand in hand with promoting development patterns that support the use of such modes, in addition to pricing strategies (for GHG, parking, gas taxes, tolls, etc) and lifestyle changes to shift from driving. In developing climate action plans, states have begun to acknowledge the connection between transportation and development patterns.

The overall goal of this research is to evaluate and learn from state-level efforts to reduce GHG from the transportation sector through improved transportation and land use policies, and to make recommendations for continuing and improving state-level efforts. Through examining the policy framework in four innovative states, studying the implementation of strategies to reduce GHG from transportation, and assessing the strengths and weaknesses of the approach, this research provides recommendations for integrating state transportation plans, state or regional land use planning, and state climate action plans to achieve GHG reduction goals.

\section{Conceptual Framework and Study Methods}

Jurisdictions set goals for reducing GHG, or closely related quantities such as VMT. To make progress towards these goals, jurisdictions create plans including strategies and policies to reduce GHG. In some cases, these plans are statewide and created by state agencies, but in some states this authority is delegated to regional or local governments. Based on the strategies adopted in plans, jurisdictions take actions in the form of regulations, processes, incentives or financial investment. Such efforts are intended to produce results (i.e., a reduction of GHG). To track progress towards goals, jurisdictions monitor GHG and produce regular monitoring reports as required by law.

This project relies on document analysis to evaluate state efforts to integrate transportation and land use planning to reduce GHG from transportation. Researchers examined statutes and analyzed state-level transportation, land use and climate plans; regulations; other plans and programs; and 
interim progress reports to obtain an understanding of relevant climate, transportation, and land use legislation and plans.

This project relies also on qualitative research methods. Between December 2014 and July 2015, the research team conducted confidential semi-structured interviews with state agency staff and other stakeholders, including metropolitan planning organizations (MPOs), local and regional associations, and nongovernmental advocacy organizations. The research team conducted 44 interviews in person or via phone. Following the conceptual framework summarized in Figure ES1, we asked each stakeholder about goals, efforts and results in their state.

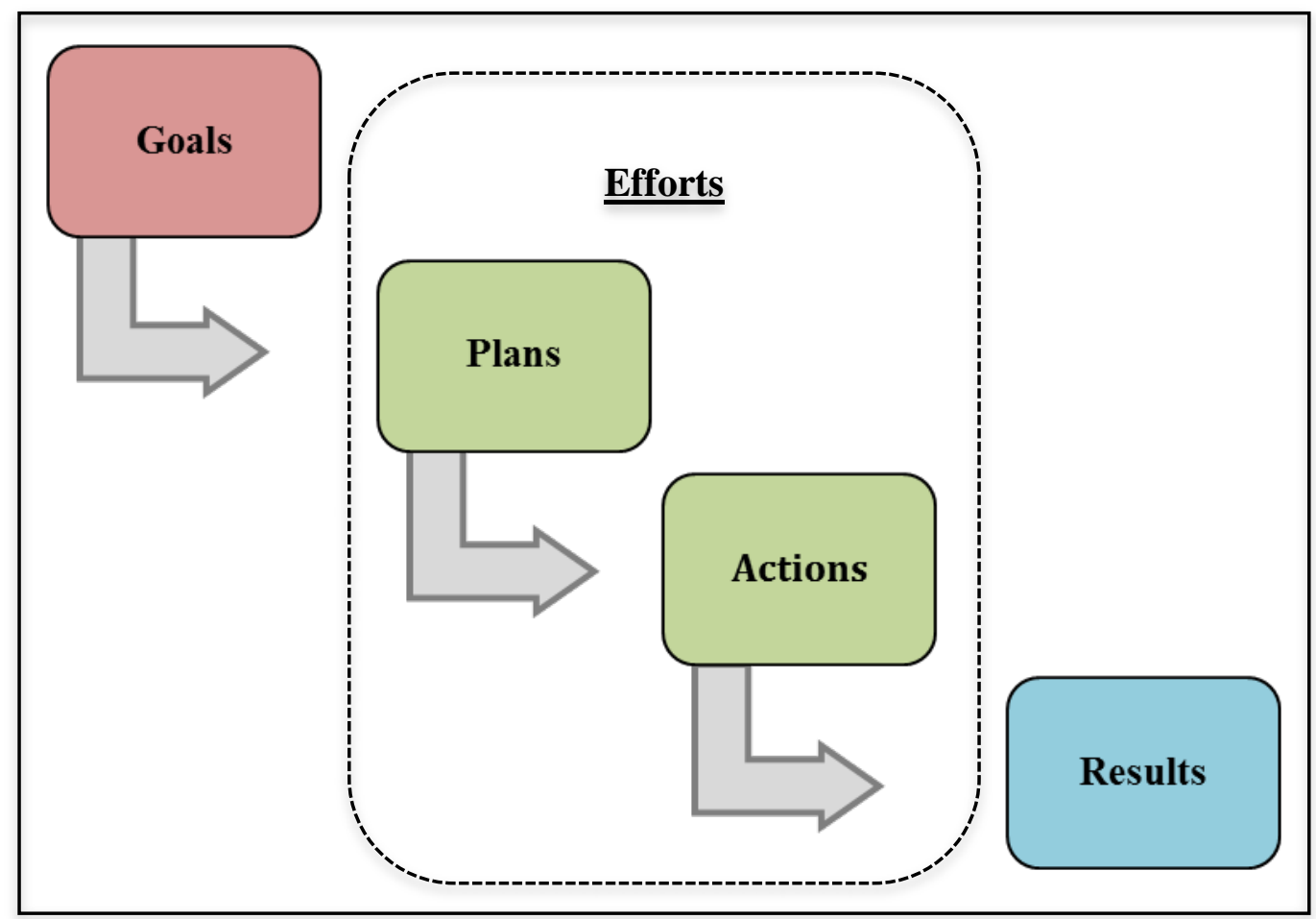

Figure ES-1: Conceptual Framework

Within the framework presented above, we organized findings by key analysis themes: leadership, policy framework, goals, planning, institutional relationships, implementation, monitoring, and regional and local support.

\section{Overview of State Approaches}

California in 2006 passed the Global Warming Act (AB32) and in 2008 adopted SB375, requiring metropolitan areas to undertake "blueprint planning" to reduce GHG from the transportation sector through a combination of transportation and land use efforts. Unlike the other three case study states, California is not considered a "growth management" state. But SB375 is an innovative approach at tying regional transportation and land use planning to achieve GHG reduction targets.

Maryland in 2009 adopted the Greenhouse Gas Emissions Reduction Act (SB278 and HB315), and in 2013 released its comprehensive Greenhouse Gas Reduction Plan. Until recently, Maryland 
had an individual state plan for transportation, climate and land use. While the statewide land use plan is no longer being implemented, Maryland is still well-known for its incentive-based Smart Growth initiatives guiding development into Priority Funding Areas.

Oregon in 2007 adopted state GHG reduction goals (HB3543), and in 2009 (HB2001) and 2010 (SB1059) adopted legislation requiring the state DOT to develop a Statewide Transportation Strategy for reducing GHG and also requiring or urging metropolitan areas to undertake "scenario planning" to reduce GHG from the transportation sector. Oregon's over 40-year-old statewide land use planning program requires cities to designate urban growth boundaries and to adopt local comprehensive plans meeting 19 Statewide Planning Goals.

Washington in 2007 (SB6001) and in 2008 (HB2815) adopted GHG reduction limits and total vehicle miles traveled reduction benchmarks (Welch, 2013). Washington in 2010 released a state climate action plan entitled Path to a Low-Carbon Economy: An Interim Plan to Address Washington's Greenhouse Gas Emissions. Washington's Growth Management Act requires local comprehensive plans and urban growth areas for jurisdictions that exceed a specified population or population growth rate.

\section{Conclusions}

A summary of key findings and recommendations appears in Table ES-1.

The states examined in this report-California, Maryland, Oregon and Washington-are progressive in adopting statutory GHG reduction goals and legislation focused on the transportation sector. While national climate legislation is lacking, these states are exemplars in adopting state-level legislation to reduce GHG. In these states, the initial legislation setting goals and requiring plans to determine how goals will be met is a starting place for making progress towards reducing GHG from transportation. Key conclusions are summarized below:

- Sustained leadership and momentum on common legislation and policies is key to successful implementation. In adopting policies, environmental groups have been important players in pushing legislation and sustaining emphasis on implementation.

- States need to "connect the dots" from goals to plans to actions to results. States lack clear monitoring authority. There is a need to link goals more directly to feasible actions and have a tighter feedback loop between goals, plans, actions and results.

- In crafting a policy designed to reduce GHG from transportation, it made sense to rely on MPOs in California and Oregon, and to allow for flexibility in how to reach targets.

- In crafting state policy, there is a clear need to align authority, responsibility and resources with those in a position to take actions. Creating new commissions that lack staff and authority has not been effective.

- Communicating with the public about GHG reduction efforts was more successful when focused on "co-benefits." 
Table ES-1: Findings and Recommendations

\begin{tabular}{|c|c|c|c|c|}
\hline \multicolumn{2}{|r|}{ Finding } & Recommendation & \multirow[t]{2}{*}{ Who? } & \multirow[t]{2}{*}{ Model } \\
\hline \multicolumn{3}{|c|}{1 Leadership } & & \\
\hline & $\begin{array}{l}\text { States leading despite } \\
\text { absence of comprehensive } \\
\text { national effort }\end{array}$ & $\begin{array}{l}\text { a) Other states should follow the lead of } \\
\text { those already addressing climate } \\
\text { change } \\
\text { b) Need comprehensive national effort }\end{array}$ & $\begin{array}{l}\text { Executive; } \\
\text { Legislature; } \\
\text { President; } \\
\text { Congress }\end{array}$ & California \\
\hline & $\begin{array}{l}\text { Political polarization makes } \\
\text { progress difficult }\end{array}$ & $\begin{array}{l}\text { Insulate implementation from the } \\
\text { political process by relying on a Climate } \\
\text { Change Commission rather than the } \\
\text { legislature }\end{array}$ & Legislature & Maryland \\
\hline 1.3 & $\begin{array}{l}\text { States learn from other states } \\
\text { (e.g., WCGGWI, WCI, PCC) }\end{array}$ & $\begin{array}{l}\text { Multistate collaboration can be helpful } \\
\text { for encouraging action }\end{array}$ & $\begin{array}{l}\text { Executive; } \\
\text { State agencies; } \\
\text { Regional } \\
\text { collaborations }\end{array}$ & $\begin{array}{l}\text { Oregon; } \\
\text { Washington }\end{array}$ \\
\hline$\overline{1.4}$ & $\begin{array}{l}\text { "Tragedy of the Commons" } \\
\text { nature of climate change } \\
\text { discourages state, regional } \\
\text { and local governments from } \\
\text { acting }\end{array}$ & $\begin{array}{l}\text { Focus on co-benefits of reducing GHG, } \\
\text { in particular, from transportation sector }\end{array}$ & $\begin{array}{l}\text { Executive; } \\
\text { Legislature; } \\
\text { State agencies; } \\
\text { MPOs }\end{array}$ & $\begin{array}{l}\text { Portland } \\
\text { MPO }\end{array}$ \\
\hline 1.5 & $\begin{array}{l}\text { Changes in political } \\
\text { leadership undermines } \\
\text { consistent implementation }\end{array}$ & $\begin{array}{l}\text { Require interim reports and sunset } \\
\text { clauses so legislature must stay engaged }\end{array}$ & Legislature & Maryland \\
\hline 1.6 & $\begin{array}{l}\text { Changes in state agency } \\
\text { leadership undermines } \\
\text { consistent implementation }\end{array}$ & $\begin{array}{l}\text { Establish a commission with broad } \\
\text { authority drawn from leaders in the } \\
\text { public and private sectors that uses } \\
\text { staggered appointment terms to insulate } \\
\text { from political changes }\end{array}$ & Legislature & Maryland \\
\hline 1.7 & $\begin{array}{l}\text { Emphasis often varies across } \\
\text { administrations; each } \\
\text { attempts to make mark with } \\
\text { new policies }\end{array}$ & $\begin{array}{l}\text { Need consistent leadership-executive, } \\
\text { legislative giving advice to agencies }\end{array}$ & $\begin{array}{l}\text { Executive; } \\
\text { Legislature }\end{array}$ & $\mathrm{n} / \mathrm{a}$ \\
\hline 1.8 & $\begin{array}{l}\text { Advocacy groups play } \\
\text { important role in pushing } \\
\text { policy agenda }\end{array}$ & $\begin{array}{l}\text { Advocacy groups push for incremental } \\
\text { policy change, calling for modest steps } \\
\text { with clear accountability to keep issue } \\
\text { present }\end{array}$ & $\begin{array}{l}\text { Advocacy } \\
\text { groups }\end{array}$ & $\begin{array}{l}1000 \text { Friends } \\
\text { of Oregon }\end{array}$ \\
\hline \multicolumn{5}{|c|}{$\begin{array}{ll}2 & \text { Policy Framework }\end{array}$} \\
\hline 2.1 & Failure to "connect the dots" & $\begin{array}{l}\text { Consider a SMART approach to } \\
\text { establishing goals, that are Specific, } \\
\text { Measurable, Actionable, Realistic and } \\
\text { Time-bound }\end{array}$ & Legislature & $\begin{array}{l}\text { Maryland; } \\
\text { California }\end{array}$ \\
\hline & $\begin{array}{l}\text { MPOs can be effective } \\
\text { instrument }\end{array}$ & $\begin{array}{l}\text { If MPOs are strong, they can be an } \\
\text { effective instrument for reducing GHG }\end{array}$ & Legislature & $\begin{array}{l}\text { California } \\
\text { (some } \\
\text { MPOs) }\end{array}$ \\
\hline
\end{tabular}




\begin{tabular}{|c|c|c|c|c|}
\hline \multicolumn{2}{|r|}{ Finding } & Recommendation & \multirow[t]{2}{*}{ Who? } & \multirow[t]{2}{*}{ Mode } \\
\hline 3 & Goals & & & \\
\hline 3.1 & $\begin{array}{l}\text { Goals often set in a vacuum } \\
\text { by legislature without } \\
\text { understanding of implications }\end{array}$ & $\begin{array}{l}\text { a) Set SMART goals } \\
\text { b) Set goals with understanding of } \\
\text { impact of existing policies, new } \\
\text { policies and new funding sources } \\
\text { c) Use a hybrid approach of "how far can } \\
\text { you get?" and "what would it take?" }\end{array}$ & $\begin{array}{l}\text { Legislature; } \\
\text { State agencies }\end{array}$ & $\begin{array}{l}\text { Baltimore } \\
\text { MPO }\end{array}$ \\
\hline 3.2 & $\begin{array}{l}\text { Often difficult to link results } \\
\text { back to actions }\end{array}$ & $\begin{array}{l}\text { Develop a set of performance measures } \\
\text { more closely tied to actions }\end{array}$ & $\begin{array}{l}\text { State agencies; } \\
\text { MPOs }\end{array}$ & Oregon \\
\hline 3.3 & $\begin{array}{l}\text { MAP-21 calls for } \\
\text { performance measures }\end{array}$ & $\begin{array}{l}\text { Regardless of federal efforts, develop } \\
\text { state and regional performance measures } \\
\text { related to GHG reduction }\end{array}$ & $\begin{array}{l}\text { State agencies; } \\
\text { MPOs }\end{array}$ & $\mathrm{n} / \mathrm{a}$ \\
\hline \multicolumn{5}{|c|}{$4 \quad$ Planning } \\
\hline & $\begin{array}{l}\text { Integrate RTPs with plans to } \\
\text { reduce GHG }\end{array}$ & $\begin{array}{l}\text { Require MPOs to show how RTPs reduce } \\
\text { GHG and give MPOs oversight over } \\
\text { project selection }\end{array}$ & $\begin{array}{l}\text { Federal } \\
\text { agencies: } \\
\text { State agencies }\end{array}$ & California \\
\hline 4.2 & MPOs vary in capacity & $\begin{array}{l}\text { Provide technical and financial support } \\
\text { for planning }\end{array}$ & State agencies & $\begin{array}{l}\text { Oregon; } \\
\text { California }\end{array}$ \\
\hline \multicolumn{5}{|c|}{$5 \quad$ Institutional Relationships } \\
\hline 5.1 & $\begin{array}{l}\text { Transportation agencies are } \\
\text { not designed to deal with } \\
\text { GHG }\end{array}$ & Use SSTI to assess transportation agency & State agencies & California \\
\hline & $\begin{array}{l}\text { Transportation agencies often } \\
\text { make all decisions related to } \\
\text { transportation placement, } \\
\text { even though decisions impact } \\
\text { land use and GHG }\end{array}$ & $\begin{array}{l}\text { Incorporate other state agencies into } \\
\text { decision-making }\end{array}$ & State agencies & $\mathrm{n} / \mathrm{a}$ \\
\hline 5.3 & $\begin{array}{l}\text { MPOs are not strong in all } \\
\text { states }\end{array}$ & $\begin{array}{l}\text { Give MPOs oversight over project } \\
\text { selection }\end{array}$ & Legislature & California \\
\hline 5.4 & $\begin{array}{l}\text { County governments are } \\
\text { strong }\end{array}$ & $\begin{array}{l}\text { Provide locals incentives to change plans } \\
\text { (tie funding to plans or UGB expansion) }\end{array}$ & State agencies & $\mathrm{n} / \mathrm{a}$ \\
\hline 6 & \multicolumn{4}{|l|}{ Implementation } \\
\hline 6.1 & $\begin{array}{l}\text { State authority over land use } \\
\text { provides an opportunity to } \\
\text { encourage compact } \\
\text { development }\end{array}$ & $\begin{array}{l}\text { Make provision of transportation funding } \\
\text { contingent on approval of land use plans } \\
\text { focused on compact development. In } \\
\text { states with strong land use planning, } \\
\text { make boundary expansion contingent on } \\
\text { scenario planning }\end{array}$ & State agencies & $\mathrm{n} / \mathrm{a}$ \\
\hline 6.2 & $\begin{array}{l}\text { Lacking flexible funding } \\
\text { sources to implement plans }\end{array}$ & $\begin{array}{l}\text { Remove constitutional limitations on gas } \\
\text { tax }\end{array}$ & Legislature & $\mathrm{n} / \mathrm{a}$ \\
\hline 6.3 & $\begin{array}{l}\text { Cap-and-trade funding } \\
\text { provides flexible funding } \\
\text { source to implement plans } \\
\end{array}$ & $\begin{array}{l}\text { Encourage competitive cap-and-trade } \\
\text { programs or carbon taxes to implement } \\
\text { plans and projects }\end{array}$ & Legislature & California \\
\hline & $\begin{array}{l}\text { Regulations prevent compact } \\
\text { development }\end{array}$ & $\begin{array}{l}\text { Relax regulations to incentivize compact } \\
\text { development, bicycle/pedestrian } \\
\text { infrastructure and transit infrastructure }\end{array}$ & Legislature & California \\
\hline
\end{tabular}




\begin{tabular}{|c|c|c|c|c|}
\hline \multicolumn{2}{|r|}{ Finding } & Recommendation & \multirow[t]{2}{*}{ Who? } & \multirow[t]{2}{*}{ Model } \\
\hline 7 & Monitoring & & & \\
\hline 7.1 & $\begin{array}{l}\text { States lack institutional } \\
\text { structure to provide oversight } \\
\text { of implementation of plans }\end{array}$ & $\begin{array}{l}\text { Provide monitoring and enforcement to } \\
\text { state agency with staff, funding, authority }\end{array}$ & Legislature & $\mathrm{n} / \mathrm{a}$ \\
\hline 7.2 & $\begin{array}{l}\text { Need to hold MPOs } \\
\text { accountable }\end{array}$ & Track VMT and GHG at MPO level & State agencies & $\begin{array}{l}\text { California; } \\
\text { Oregon }\end{array}$ \\
\hline 7.3 & $\begin{array}{l}\text { Plans are not monitored for } \\
\text { implementation }\end{array}$ & $\begin{array}{l}\text { Rely on public sector or civic sector to } \\
\text { monitor plans }\end{array}$ & $\begin{array}{l}\text { State agencies; } \\
\text { Civic sector }\end{array}$ & California \\
\hline 8 & Regional and Local Support & & & \\
\hline 8.1 & $\begin{array}{l}\text { Citizen buy-in important to } \\
\text { sustained efforts }\end{array}$ & $\begin{array}{l}\text { Build public support by emphasizing co- } \\
\text { benefits of reducing GHG }\end{array}$ & $\begin{array}{l}\text { Public } \\
\text { agencies }\end{array}$ & All \\
\hline & $\begin{array}{l}\text { Difficult to get buy-in as state } \\
\text { agencies }\end{array}$ & Rely on civic sector to build coalitions & Civic sector & $\begin{array}{l}\text { Maryland; } \\
\text { California }\end{array}$ \\
\hline
\end{tabular}




\subsection{INTRODUCTION}

Policymakers and planners in the United States increasingly recognize climate change as a critical challenge. "Human influence on the climate system is clear ... Recent climate changes have had widespread impacts on human and natural systems" (International Panel on Climate Change, 2014, 2). "Climate change is already affecting the American people in far-reaching ways. Certain types of extreme weather events with links to climate change have become more frequent and/or intense, including prolonged periods of heat, heavy downpours, and, in some regions, floods and droughts" (Melillo, Richmond and Yohe, 2014, 7). "Continued emission of greenhouse gases will cause further warming and long-lasting changes in all components of the climate system, increasing the likelihood of severe, pervasive and irreversible impacts for people and ecosystems. Limiting climate change would require substantial and sustained reductions in greenhouse gas emissions, which, together with adaptation, can limit climate change risks" (International Panel on Climate Change, 2014, 8).

Although the United States has less than 5 percent of the world's population, it is responsible for almost 12 percent of the world's greenhouse gas emissions (GHG). Table 1.1 summarizes total and per capita GHG globally, and $\mathrm{CO}_{2}$ emissions (the largest component of GHG) for the U.S. and four case study states.

Table 1.1: 2010 Greenhouse Gas Emissions

\begin{tabular}{|l|r|r|r|}
\hline \multicolumn{1}{|c}{ Geography } & \multicolumn{1}{c}{ Total Emissions } & \multicolumn{1}{c|}{ Population } & \multicolumn{1}{c|}{ Emissions per Capita } \\
\hline World & $49,000 \mathrm{MMTCO}_{2} \mathrm{e} / \mathrm{yr}$ & $6,900.0$ million & $7.1 \mathrm{MTCO}_{2} \mathrm{e} / \mathrm{yr}$ \\
\hline United States & $5,493.8 \mathrm{MMTCO}_{2} / \mathrm{yr}$ & 309.3 million & $17.8 \mathrm{MTCO}_{2} / \mathrm{yr}$ \\
\hline California & $358.4 \mathrm{MMTCO}_{2} / \mathrm{yr}$ & 37.3 million & $9.6 \mathrm{MTCO}_{2} / \mathrm{yr}$ \\
\hline Maryland & $67.7 \mathrm{MMTCO}_{2} / \mathrm{yr}$ & 5.8 million & $11.7 \mathrm{MTCO}_{2} / \mathrm{yr}$ \\
\hline Oregon & $39.9 \mathrm{MMTCO}_{2} / \mathrm{yr}$ & 3.8 million & $10.4 \mathrm{MTCO}_{2} / \mathrm{yr}$ \\
\hline Washington & $74.2 \mathrm{MMTCO}_{2} / \mathrm{yr}$ & 6.7 million & $11.0 \mathrm{MTCO}_{2} / \mathrm{yr}$ \\
\hline
\end{tabular}

Source World: (International Panel on Climate Change, 2014).

Source U.S: (U.S. Energy Information Administration, 2015; U.S. Census Bureau, 2016).

Although there is not yet a comprehensive national response, several states have adopted ambitious goals to reduce GHG linked to climate change (Center for Climate and Energy Solutions, 2016). To achieve their goals, these states have adopted policies and strategies or delegated authority to the regional or local level.

GHG from the transportation sector constitute approximately one-third of all emissions in the U.S. (U.S. Environmental Protection Agency, 2016a). Approximately 60 percent of transportation sector emissions come from passenger cars or light-duty vehicles while the remainder comes from freight, aircraft, rail, ships and boats (U.S. Environmental Protection Agency, 2016a).

Reducing GHG from transportation rests on the "three-legged stool" of improving vehicle efficiency, reducing the carbon content of fuels and reducing vehicle miles traveled (VMT) (Ewing et al., 2007, 2). Even if the federal government adopts stringent standards for vehicle efficiency (CAFE standards) and fuel content changes, rising VMT will outweigh gains in these two sectors. 
Total VMT generally rises with increasing population and, in recent years, VMT growth has outpaced population growth. VMT per capita has been rising as communities grow in size and people tend to take more and longer trips, leading to total VMT growing faster than population. From 1990 to 2014, total VMT increased by 37 percent (U.S. Environmental Protection Agency, 2016a) while population increased by only 28 percent (U.S. Census Bureau, 2012; U.S. Census Bureau, 2014). Recent data shows that VMT per capita is beginning to increase again following the Great Recession, although VMT has not risen to pre-Great Recession levels in all states (U.S. Federal Highway Administration, 2015). Though recent evidence suggests that millennials are driving less, it is unclear whether this trend will continue in the future (McDonald, 2015).

Thus, to reduce GHG from transportation, it is important to focus on reducing VMT. In this study, we focus on state-level attempts to reduce transportation emissions by reducing VMT. In Figure 1.1, the blue boxes highlight the key focus of this report.

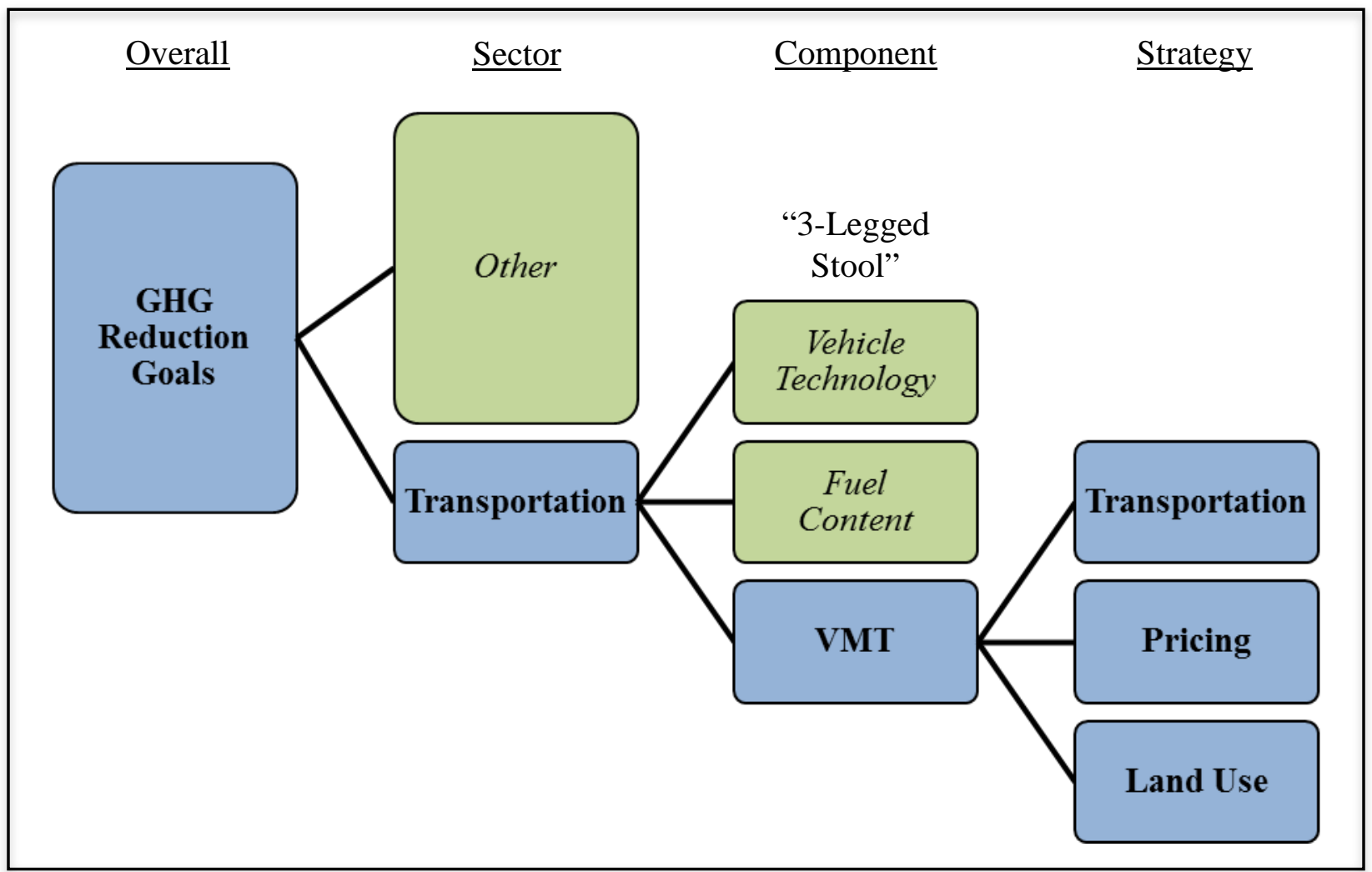

Figure 1.1: Focus of Research

Acknowledging this connection, several state-level strategies involve reducing GHG by shifting transportation modes and promoting compact development patterns. Unlike many of the strategies related to vehicle efficiency and fuel content, which may be achieved through top-down federal action, reducing VMT requires changes in local policy and individual choices. Research has shown that VMT can be reduced by encouraging use of other transportation modes (e.g., transit, biking and walking); by making driving more expensive through pricing (e.g., carbon tax); and by altering land use so destinations are closer together (e.g., higher density). Behavior change is necessary to reduce VMT (Burbank, 2009). Although concerns around climate change provide an additional 
reason, some states already have been using transportation planning to provide alternative modes and land use planning to encourage compact development for several decades.

In this report, we examine how four states-California, Maryland, Oregon and Washington — that have passed legislation related to reducing GHG are seeking to reduce GHG from the transportation sector by reducing VMT.

The overall goal of this research is to evaluate and learn from state-level efforts to reduce GHG from the transportation sector through improved transportation and land use policies, and to make recommendations for continuing and improving state-level efforts. Specifically, the research questions and objectives are:

1. Policy Framework: What is the framework for reducing GHG via transportation and land use strategies?

Objective: Document and describe the policy context for reducing GHG from transportation in the case study states.

2. Assessment: What are strengths and weaknesses of each state's approach to achieving GHG reduction goals for the transportation sector?

Objective: Assess each state's policy framework for achieving GHG goals through transportation and land use strategies.

3. Knowledge Transfer: What approaches are working well in the four case study states and what can they learn from each other? In the absence of federal leadership, what can the other 46 states learn from the four case study states to be more effective in reducing GHG from the transportation sector through transportation and land use strategies?

Objective: Provide transferable knowledge of effective policy frameworks for reducing GHG from the transportation sector.

By examining the policy framework in four innovative states, studying the implementation of strategies to reduce GHG from transportation, and assessing the strengths and weaknesses of the approach, this research will provide valuable information to policymakers and state agency staff in case study states and others. This research will provide recommendations for reducing GHG from transportation at the state level.

This report proceeds as follows: Relevant literature on reducing GHG from the transportation sector, state climate action plans and implementation research are summarized. Then, we present a conceptual framework explaining the process for setting goals, adopting plans, taking actions and reducing GHG. Next, we provide a short profile of each state, describing demographics, government structure, transportation planning and land use planning within each state. Next, we summarize the approach in each state, looking first at goals and then at efforts, including monitoring and results. Then, information from our four case study states is synthesized, summarizing key similarities and differences among state approaches and describing key strengths and weaknesses as described by stakeholders. Next, key findings and recommendations learned 
from efforts in the case study states are described. Finally, we close with conclusions and implications for future work. 


\subsection{LITERATURE REVIEW}

Three primary bodies of literature inform this work. First, we summarize studies that assess state climate action plans. Second, it is important to summarize studies that establish the connection between reducing GHG from transportation and reducing VMT. Finally, we describe the literature on vertical (between state, region and local) and horizontal (across state agency) coordination, which are important aspects in the approaches used by case study states.

\subsection{STATE CLIMATE ACTION PLANS}

In the absence of national policy leadership in the United States, the policy vacuum at the federal level has opened a window for cities and states to rely on federal funding to undertake initiatives and exercise autonomy in devising and implementing climate policy (Bulkeley, 2010; Rabe, 2004). To plan for reducing GHG, several states have adopted state climate action plans. As of 2014, approximately 34 states have created state climate action plans, and 29 states have adopted some kind of GHG reduction goal (Center for Climate and Energy Solutions, 2016; U.S. Department of State, 2014). To meet GHG reduction goals, states include a broad spectrum of policies covering energy efficiency and renewable energy, and many of these climate action plans include GHG reduction strategies related to transportation. Among GHG reduction strategies, "efficient vehicles" and "reduced fuel use" are the fourth and fifth most popular strategies in state climate action plans, respectively (Pollak, Meyer and Wilson, 2011).

Rabe (2008) examines various types of policy approaches for a state-centric approach to reducing GHG, focusing on emission trends and policy adoption rates. Rabe (2008) focuses on state approaches that could be integrated with a federal policy. A few scholars have offered assessments of state climate action plans (Wheeler, 2008), and offered guidance for improving state climate action plans. In assessing the first generation of municipal and state climate action plans, Wheeler identified key weaknesses in early plans: inadequate goals, lacking strong actions, and institutional and political commitment. Wheeler recommends stronger near-term goals; robust monitoring and progress reporting; a broader range of actions; and changing policies, regulations and incentives to reduce GHG, moving beyond existing actions. Other scholars have synthesized the research on climate change and transportation research at state agencies and universities (ICF International, 2011). Many of these articles provide guidance for selecting greenhouse gas reduction strategies but overlook the challenge of implementation and agency coordination. A few short, new articles discuss various approaches to implementation in specific U.S. states. A 2012 issue of TR News focused on state and local action on climate change, focusing on agency implementation (Noland and Burbank, 2012; Johnson, Annelin and Schuster, 2012; Campoli, 2012). Further, Turner, Frazier and Kaiser (2009) outline the course of action for implementation in Maryland and predict potential challenges. Barbour and Deakin (2012) evaluate the progress of implementing Senate Bill 375 in California, focusing on the local and metropolitan level. 
Several scholars have focused on cities filling the gap in policy in the lack of federal and sometimes state action (Boswell, Greve and Seale, 2010; Bulkeley and Betsill, 2003; Bulkeley and Betsill, 2013; Boswell, Greve and Seale, 2012).

While several states have created climate action plans, many of which contain transportation and land use strategies, and a few states have gone further in enacting GHG goals and strategies into law, research on implementing state climate action plans and state agency coordination is sparse.

\subsection{REDUCING VMT}

Several scholars have explored the connection between VMT and development patterns. Several studies describe the relationship between VMT and urban form, discussing density, diversity and design (Ewing and Cervero, 2001; Crane, 2000). Three recent studies_Growing Cooler, Moving Cooler and Driving and the Built Environment-summarize the relationship between VMT and development patterns, finding that compact development reduces VMT by 20 to 40 percent (Ewing et al., 2007; National Research Council, 2009; Cambridge Systematics, 2009). Driving and the Built Environment summarized existing studies, finding that doubling residential density reduces VMT by 5-12 percent but combining with mixed use and transportation reduces VMT by up to 25 percent. In this report, we do not provide a full description or critique of the variation in the range of findings on the connection between VMT and development, but refer to this existing literature to provide support for the assumption that development patterns impact VMT.

\subsection{VERTICAL AND HORIZONTAL CONSISTENCY}

Though several states are beginning to acknowledge the relationship between transportation, land use and climate change and some have implemented policies to reduce GHG by focusing on VMT, institutional barriers slow progress. Even in states with growth management or state land use programs, land use decisions occur at the local level while state transportation planning is centralized at the state level and MPOs complete their own long-range transportation plans. In attempting to reduce GHG from transportation, progress has been slow because of differing levels of authority over complex, overlapping policy issues.

Achieving GHG reduction strategies depends on coordination among state agencies and between state, regional and local governments. Burby and May (1997) provide a framework for analyzing the policy design of state planning mandates in three types of consistency requirements, including vertical, horizontal and internal consistency. Vertical consistency refers to state mandates that local plans are consistent with state policies and goals. Horizontal consistency refers to consistency among neighboring local governments. Internal consistency relates to the relationship between planning and zoning at the local level. Though this framework has been applied to describe and analyze growth management strategies by several scholars, prior studies focus primarily on local plans and horizontal relationships among local governments rather than state agencies (Weitz ,1999; Gale, 1992; Baer, 1997; Carruthers, 2002; Howell-Moroney, 2007; Wassmer, 2006). Lewis and Knaap (2012) extend this framework to state agencies in evaluating state development plans. At the state level, horizontal consistency describes the level of coordination between state agencies and integration of various plans at the state level. Vertical consistency refers to the application of state policies and plans at the local level. Though Lewis and Knaap focus on state development 
plans, this framework is even more relevant in discussing the integration of transportation, climate change and land use planning, which rely on various state agencies.

Drawing on research from land use planning on horizontal and vertical implementation, we examine the vertical and horizontal implementation mechanisms related to transportation and land use policies to reduce VMT.

\subsection{RESEARCH GAP}

Several states have created state climate action plans, but the content and enforceability of those plans varies. Transportation is not as a key strategy embedded in all state climate action plans. Some states are beginning to acknowledge the relationship between transportation, land use and climate change, and some have implemented policies to reduce GHG by targeting VMT. Thus far, there has been limited research on climate action plans. Land use decisions occur at the local level, even in growth management states, while transportation planning is centralized at the state level. In attempting to reduce GHG from transportation, progress has been limited because of differing levels of authority over complex, overlapping policy issues. Thus, it is important to examine vertical and horizontal coordination around implementation. 



\subsection{METHODOLOGY}

In this section, we describe the conceptual framework for how states are working to reduce GHG, especially from the transportation sector. We describe the methods used to address our key research questions: document analysis and stakeholder interviews.

\subsection{CONCEPTUAL FRAMEWORK}

In order to reduce GHG, federal, state, regional and local governments generally follow a consistent general process. See Figure 3.1.

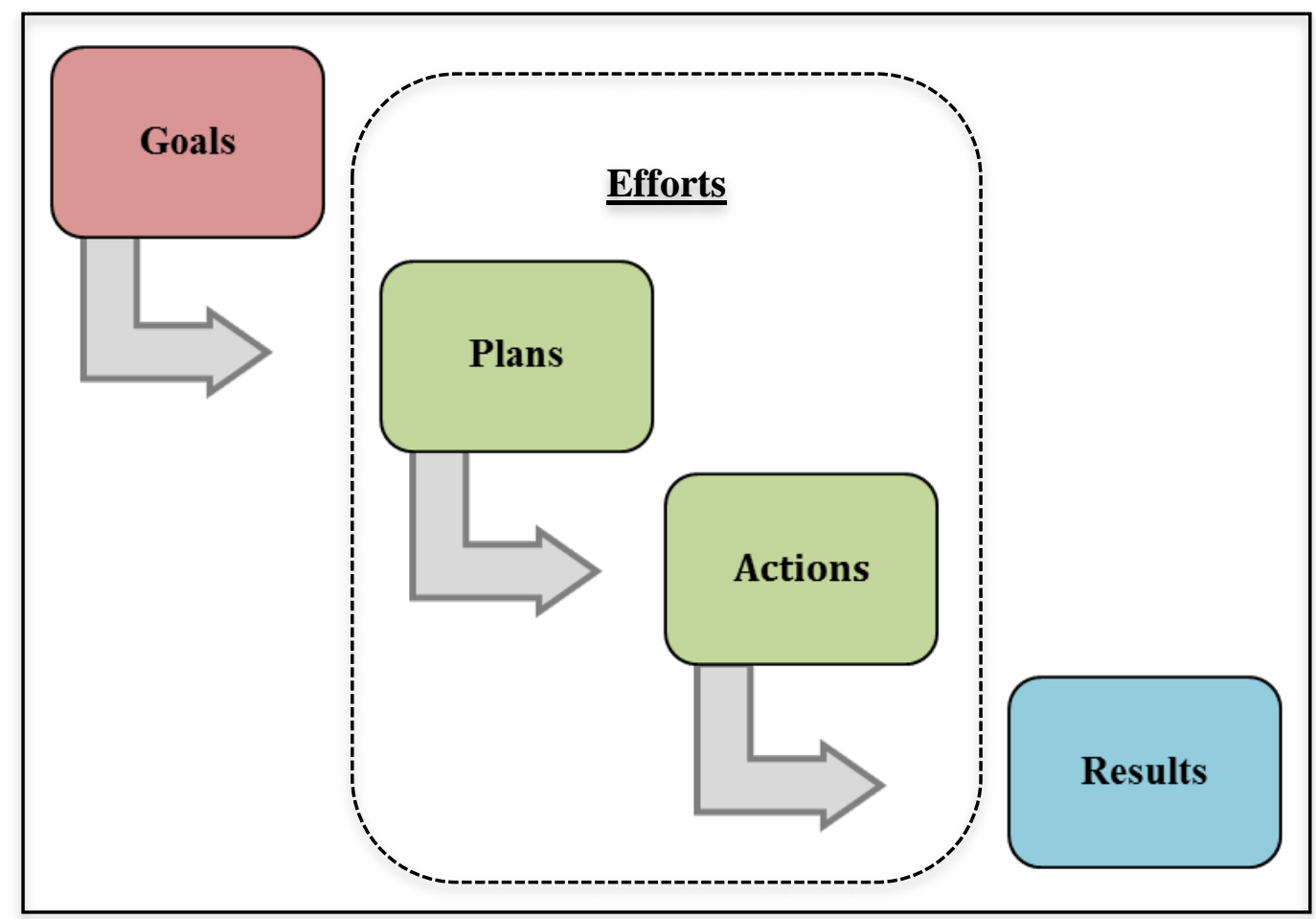

Figure 3.1: Conceptual Framework

Jurisdictions set goals for reducing GHG, or closely related quantities such as VMT. To make progress towards these goals, jurisdictions create plans, including strategies and policies, to reduce GHG. In some cases, these plans are statewide and created by state agencies, but in some states this authority is delegated to regional or local governments. Based on the strategies adopted in plans, jurisdictions take actions in the form of regulations, processes, incentives or financial investment. Such efforts are intended to produce results (i.e., a reduction of GHG). To track progress towards goals, jurisdictions monitor GHG and produce regular monitoring reports as required by law. 


\subsubsection{Goals}

In the context of state governments, a policymaking branch like the governor or legislature adopts goals (desired outcomes and time frames) for reducing GHG. A goal is a quantitative (or qualitative) statement to reduce GHG linked to climate change, or to achieve other outcomes directly linked to doing so, for example, reducing VMT.

Before or after setting these goals, governments create inventories of GHG and often examine projections for GHG. In our four case study states these goals were adopted in state statute, sometimes following leadership from the executive in addition to formal actions like executive orders.

Different states use the terms goals, limits, targets or benchmarks with slightly different meanings. In this research, the term goal is generally used to represent intent to reduce GHG from all sectors statewide. The term target is generally used to represent intent to limit GHG (or a closely related quantity such as VMT) from only the transportation sector or a subsector such as light-duty vehicles, often for just a region of the state.

\subsubsection{Efforts}

In order to achieve GHG reduction goals, states undertake various efforts. An effort is a law, resolution, agreement, executive order, regulation, plan, policy, strategy, study, report, public investment, incentive, tax, fee, educational program, or other public-sector effort that is intended, directly or indirectly, to result in some reduction of GHG, especially from the transportation sector. Efforts include both plans and actions, described below.

States adopt climate action plans that offer potential and recommended strategies and policies for reducing GHG. In the United States, climate action plans "lay out a strategy, including specific policy recommendations, that a state will use to address climate change and reduce its GHG” (U.S. Environmental Protection Agency, 2016b). These plans typically include key elements like GHG inventories, specific goals, strategies or policies, and implementation mechanisms. The first two steps in the process reflect the "formulation and adoption of policy," as defined by Mazmanian and Sabatier (1989). As detailed in Sections 5.0 and 6.0, there is considerable variation in these "plans” across states. Some states, like Maryland, publish a comprehensive state-level plan, while other states like Oregon and California delegate authority for adopting strategies to the regional level.

Consistent with the strategies adopted in climate action plans, states take actions to reduce GHG. Actions might include mandates, processes, incentives or financial investment. Actions capture what a state is doing to reduce GHG by reducing VMT, while plans express what the state wants to do. This is the implementation phase of policymaking, as described by Mazmanian and Sabatier (1989). While many policy analyses ignore the question of implementation and focus on the outcomes of legislation, the implementation phase is a critical step in the process, particularly when trying to determine which policies were effective (Smith, 1973). 


\subsubsection{Results}

Finally, the results reflect the trends in VMT and GHG over time. A result is a measurable change in GHG, or in a closely related quantity, as well as efforts to monitor, report and respond to such measurements. The key results are whether VMT and GHG declined over time.

As required by statute, many states publish annual or biennial reports and incorporate key evaluation dates into statutes. It is important to note that it is difficult to link specific actions to results in the case of GHG. Because external factors like fuel costs or economic recession might impact VMT, as evident in the last several years in the U.S., the success of state plans to reduce VMT is difficult to disentangle.

\subsection{DOCUMENT ANALYSIS}

This project relies on document analysis to evaluate state efforts to integrate transportation and land use planning to reduce GHG from transportation. Researchers examined statutes and analyzed state-level transportation, land use and climate plans; regulations; other plans and programs; and interim progress reports to obtain an understanding of relevant climate, transportation, and land use legislation and plans.

\subsection{STAKEHOLDER INTERVIEWS}

This project relies also on qualitative research methods. Between December 2014 and July 2015, the research team conducted confidential semi-structured interviews with state agency staff and other stakeholders, including MPOs, local and regional associations, and nongovernmental advocacy organizations. After obtaining Institutional Review Board approval, the research team conducted 44 interviews in person or via phone. Following the conceptual framework summarized in Figure 3.1, we asked each stakeholder about goals, efforts and results in their state. The conceptual framework was broad enough to enable researchers to probe different aspects of each state's approach without prejudging what might be learned. Interviews focused on understanding the policy framework within each state and investigating the strengths, weaknesses and best practices from each state. Interview questions were slightly adapted for each individual interview. Appendix A presents sample interview questions. Appendix B presents a list of organizations interviewed. We do not use direct quotes or identify stakeholders by name because we promised confidentiality to interviewees.

\subsection{ANALYSIS THEMES}

After conducting document analysis and stakeholder interviews, the research team began organizing state approaches, strengths and weaknesses, findings and recommendations into a set of more refined themes. See Figure 3.2. 


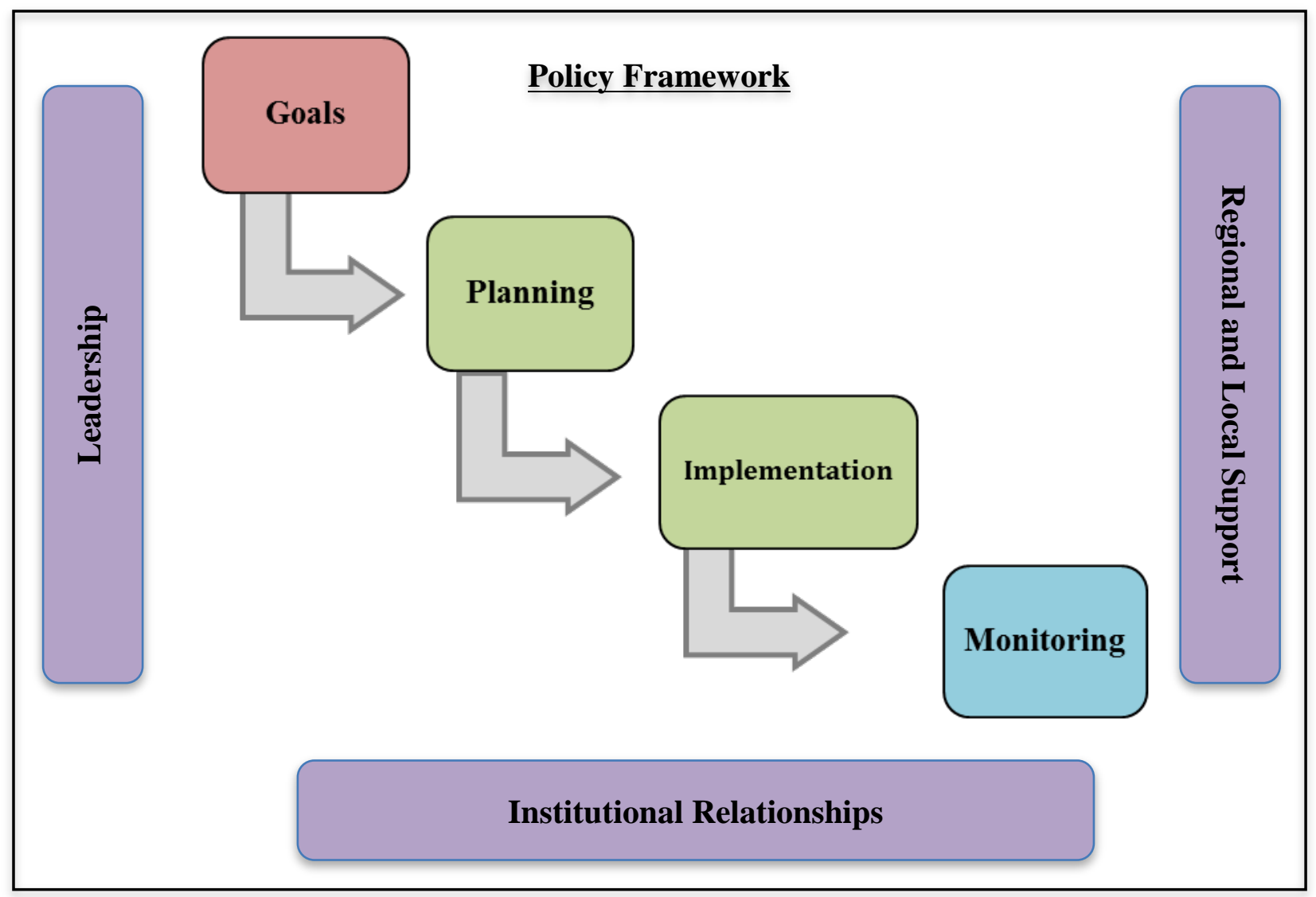

Figure 3.2: Analysis Themes

The themes are:

- Leadership: motivation, vision and (executive) leadership

- Policy Framework: how key legislation is structured

- Goals: overall GHG reduction goals and transportation-specific targets

- Planning: aspects of state, regional and local planning processes

- Institutional Relationships: relationships between state, regional and local agencies, focusing on horizontal relationships among agencies at the same level and vertical relationships between levels

- Implementation: aspects of implementing plans, strategies and policies

- Monitoring: tracking progress towards goals and targets, reporting, and revising goals or efforts in response

- Regional and Local Support: developing support for regional and local efforts 


\subsection{CASE STUDY STATES}

Approximately 34 states have created state climate action plans (Center for Climate and Energy Solutions, 2016). In this project, the research team will focus on four states known for innovative climate action plans, innovative state-level land use policy, or both: California, Maryland, Oregon and Washington. Maryland, Oregon and Washington are growth management states that have also passed state-level climate legislation. While California is not known for state-level growth management, the state passed an innovative bill (SB375) that integrates transportation and land use planning at the regional level to reduce GHG.

We briefly profile each state below. Because our study evaluates four states, it is important to gain an understanding of the key differences in demographics and politics that underlie the policy choices related to climate change, land use and transportation.

\subsection{CALIFORNIA}

California in 2006 passed the Global Warming Act (Assembly Bill 32) and in 2008 adopted Senate Bill 375, requiring metropolitan areas to undertake "blueprint planning” to reduce GHG from the transportation sector through a combination of transportation and land use efforts. Unlike the other three case study states, California is not considered a "growth management" state. But SB375 is an innovative approach at tying regional transportation and land use planning to achieve GHG reduction goals.

\subsubsection{Demographics}

With a population of more than 38 million, California is the most populous state in the U.S. At 163,000 square miles, California is the second largest state by area and the $11^{\text {th }}$ most dense state at 246 people per square mile. Eleven of the nation's 100 largest metropolitan areas are in California. Growth in California has been a constant for much of the state's history, and the state consistently experiences one of the highest growth rates in the country every year. While California still has the $16^{\text {th }}$ highest growth rate in the country (U.S. Census Bureau, 2014), growth has slowed, largely due to high levels of emigration to predominantly western states.

\subsubsection{Government Structure}

California has a large and complicated state government. The executive branch, led by oftencharismatic governors, regularly leads in innovative policy reform.

State agencies are large and powerful, and enjoy significant autonomy in rulemaking and regulation. There are seven massive cabinet-level "superagencies" that each house many departments. The California Environmental Protection Agency (CalEPA) is one such superagency, and has a total budget of $\$ 4.8$ billion (2015) and over 4,500 full-time employees. Within CalEPA are seven departments, including the California Air Resources Board (CARB), which has a budget 
of \$339 million (2015) and 1,225 full-time employees within the overall CalEPA (California Department of Finance, 2016). In addition to the seven superagencies, there are seven other independent state agencies not housed within superagencies, such as the Department of Education and the Department of Food and Agriculture.

The Assembly and Senate function in a standard bicameral legislative system and are both full time. Within both chambers, fiscal and policy committees undertake a high volume of legislative work, especially the budget committees, which must review the governor's budget each January and submit a final budget for the governor's signature by June 15 every year.

Direct democracy is also a powerful force in California, with voters able to change state law and policy through initiatives, referendums, recalls and ratifications. Between 1970 and 2006, 176 voter initiatives qualified for the ballot, and 84 of them, or 48 percent, passed with voter approval (Hodson, 2009a). Many have argued that since the passage of Proposition 13 in 1978, which demonstrated the power of referendum and initiative, the legislature has lost some power over certain policy areas and the state budget (Economist, 2011).

The California Environmental Quality Act (CEQA) was passed in 1970, less than a year after the National Environmental Policy Act (NEPA) on which CEQA is modeled. Whereas NEPA regulates the environmental impact of federal or federally funded actions, CEQA regulates the environmental impact of projects or plans to be carried out or approved by state agencies. CEQA requires state agencies to reject projects when feasible alternatives or feasible mitigation measures that would substantially lessen significant environmental effects of the project are available. Stemming from this vague language, the first 45 years of CEQA has brought an extensive canon of litigation over the CEQA review process.

\subsubsection{Transportation Approach}

State-level transportation planning authority in California is concentrated in a single agency, the California Dept. of Transportation (Caltrans). A separate Office of Interagency and Regional Planning oversees coordination between Caltrans districts and regional MPO transportation projects and planning. Caltrans, housed in the super-agency California State Transportation Agency (CalSTA), is charged with developing and implementing the California Transportation Plan (CTP), the state's comprehensive, transportation planning document. Caltrans is responsible for planning the state highway system, accounting for 55 percent of the state's total road miles, with local and regional planning organizations overseeing the remaining 45 percent of total road miles (California Department of Transportation, 2015).

Regional government in California, in the form of MPOs, gained influence with 1997's SB45, which transfers a significant amount of federal transportation funding away from state oversight and directly into the hands of MPOs. SB45 drastically redistributed central transportation planning authority from Caltrans' California Transportation Commission to the state's Regional Transportation Planning Associations, which aside from a notable exception in the Bay Area, are congruent with the state's 18 MPOs. SB45 gave MPOs 75 percent of the programming authority over capital improvement projects, with only 25 percent retained by Caltrans. The 75 percent of programming authority delegated to MPOs is planned in Regional Transportation Improvement Plan (RTIP), while the 25 percent retained by Caltrans is planned in the Interregional 
Transportation Improvement Plan (California Department of Transportation, 2015). Under SB45, the California Transportation Commission must either accept or reject the MPOs' RTIP entirely, preventing the Commission from vetoing individual projects.

In total, 18 MPOs span the state, with the Southern California Association of Governments as the nation's largest MPO with a population of around 18 million people. MPOs must complete regional transportation plans (RTPs) under federal law, and many MPOs, including SANDAG and ABAG, are choosing to integrate their SB375 Sustainable Communities Strategies directly into their federally mandated RTPs. While local governments retain authority over land use decisions, their overall planning authority is tempered by MPOs’ authority over most transportation project funding approval.

\subsubsection{Land Use Approach}

Owing to its early development and rapid growth rates relative to other western states, California has been a leader in many areas of public policy and planning (Fulton, 2015). In 1927, the state legislature mandated that every municipality create a "general plan," which became the blueprint for the now-common comprehensive plan of American cities. This early land use regulatory authority granted to local governments created a local control tradition that remains an influential force in California today.

Under the local planning system, general plans are required to incorporate a wide set of planning issues, including land use, circulation, housing, conservation, open-space, noise and safety (California Government Code §65302). The California Office of Planning and Research issues guidelines for state plans and the Institute for Local Government offers guidance and technical support, but there is no state or regional review of local plans for California's 482 incorporated municipalities. Citizens have a legal right to challenge specific zoning decisions through ballot initiatives. Further, a provision in the 1970 California Environmental Quality Act (CEQA) allows for citizen lawsuits in local planning projects. Together, these rights have allowed strong citizen influence in the planning process. Additionally, the state-mandated municipal general plans do not require regional analyses (Fulton, 2015, 5).

\subsubsection{Context Summary}

Demographic conditions, government structure, politics, and existing land use, and transportation authority provide important context for the structure of SB375-California's hallmark legislation focusing on reducing GHG from transportation. California is a geographically large and populous state with a history of strong local land use planning and powerful MPOs. While the public initiative and referendum process is strong, many of the innovative climate policies for which California is well-known have emerged from the governor and professional, majority-Democratic legislature.

\subsection{MARYLAND}

In 2009, Maryland adopted the Greenhouse Gas Emissions Reduction Act (Senate Bill 278 and House Bill 315), and in 2013 released its comprehensive Greenhouse Gas Reduction Plan. Until recently, Maryland had individual state plans for transportation, climate and land use. While the 
statewide land use plan is no longer being implemented, Maryland is still well-known for its incentive-based Smart Growth initiatives guiding development into Priority Funding Areas.

\subsubsection{Demographics}

With a 2015 population of 6 million and land area of 9,707 square miles, Maryland is the fifth densest state in the country at 619 people per square mile (U.S. Census Bureau, 2015). Ranked first in the country for median household income, it is also one of the wealthiest states. The capitol, Annapolis, has a population of 39,000. The largest city, Baltimore, has a population of 2.2 million people in the metro area, and is the largest independent city in the country, meaning the city does not lie within any county and is treated as a county-equivalent.

\subsubsection{Government Structure}

The Maryland legislature is bicameral, with a General Assembly of 141 members serving twoyear terms, and a Senate of 47 members serving four-year terms. Both houses are part time, and most legislators have jobs outside of office. The legislative sessions are just 90 days long, lasting from January to April. Legislators are often constrained by time and resources in their legislative efforts, creating a somewhat weak institution that is often easily influenced by the policy agenda of the governor's office (Curry, 2009).

Maryland's executive branch is led by one of the most powerful governorships in the nation (Curry, 2009). The governor has appointment and removal power over all cabinet-level positions, as well as hundreds of other positions in the executive branch. The only other independently elected officials in the executive branch are the lieutenant governor (who is elected on the same ticket with the governor), comptroller and attorney general. The governor also has considerable influence over the state budget. Each agency in the executive branch submits a budget proposal to the governor; the governor reviews, edits and submits budgets to the legislature; and the legislature can reduce, but not increase, budgetary amounts. The governor also has line-item veto powers over legislative bills.

Under two progressive governors, Parris Glendenning and Martin O’Malley, in the late 1990s and again in the late 2000s, Maryland set in place several innovative policies to manage growth and combat climate change. Governor Glendening's 1997 Smart Growth and Neighborhood Conservation initiative created a groundbreaking, state-level incentive system that provides large amounts of the state budget to priority development areas while withholding any funding from priority resource land and conservation areas (Curry, 2009). The elections of fall 2014 brought a significant change in state leadership with the election of Republican Governor Larry Hogan.

Counties, rather than cities, have predominant control over local affairs in Maryland. Eight out of 24 counties have home-rule charters, granting them significant autonomy in policymaking. Three other counties have a limited form of home rule. Maryland's remaining 13 counties largely act as agents of state policy, and laws passed in those counties must be ratified by the state legislature (Curry, 2009). 


\subsubsection{Transportation Approach}

Maryland uses several overlapping plans and policies to guide transportation decisions under the direction of the Maryland Department of Transportation (MDOT). The package of plans referred to as the State Report on Transportation includes three documents: the Maryland Transportation Plan (MTP), the Consolidated Transportation Plan and the Attainment Report (Maryland Department of Transportation, 2014a, 1).

Updated in 2014, the Maryland Transportation Plan (MTP) is a 20-year vision which serves as “a strategic roadmap for transportation” (Maryland Department of Transportation, 2014a, 3). The document outlines goals, objectives, challenges and priorities, providing a framework for making funding decisions. The plan is organized around six goals: Safety and Security, System Preservation, Quality of Service, Environmental Stewardship, Community Vitality and Economic Prosperity.

The MTP relies on Transportation Place Types (similar to PlanMaryland Planning Areas, described in the next section) to illuminate the connection between existing land use and transportation needs. These types include: Urban Centers, Towns and Suburban Centers, Rural and Agricultural Areas, and Natural Areas. The plan is organized under a regional framework in which key strategies are defined for each region of the state. Under each of these key strategies, the plan identifies relevant place types affected by the strategy.

Additionally, the agency publishes an annual Attainment Report on Transportation System Performance, which serves as a progress report for meeting key goals identified in the MTP. The Attainment Report provides key performance metrics along each goal and offers future performance strategies.

\subsubsection{Land Use Approach}

Since the passage of the 1997 Smart Growth package of legislation, Maryland has been seen as a leader in state growth management.

In the 1980s, concern for the Chesapeake Bay pushed Maryland to embrace innovative land use and environmental policy (Lewis, Knaap and Sohn, 2009). The 1992 Economic Growth, Resource Protection and Planning Act required local governments to revise comprehensive plans to include specific elements and address seven visions (now 12, as of 2009) based on broad statements of principle. Comprehensive plans must be revised every 10 years, and plans are reviewed by the Maryland Dept. of Planning (MDP), but the department does not have approval authority over local comprehensive plans.

In 1997, the state legislature passed a package of legislation collectively referred to as the "smart growth" package: the 1997 Smart Growth and Neighborhood Conservation Initiative, including five components. Underlying these policies is the idea that the state should not subsidize sprawl development and resources should be targeted into areas with existing infrastructure (Cohen, 2002). Two programs encompass the core of the legislation: the Smart Growth (Priority Funding) Areas Act and the Rural Legacy Program, which represent the "inside/outside" strategy. 
Under the Smart Growth Areas Act, state funding for new roads, water and sewer infrastructure, and some housing and economic development programs must occur in existing developed areas or areas planned for growth (Priority Funding Areas).

So-called "growth-related" spending is limited to locally designated and state-reviewed Priority Funding Areas. By statute, these areas include incorporated municipalities, areas inside the Washington and Baltimore beltways, and other areas as defined by statutory criteria and designated by local governments. Growth-related spending includes certain types of spending from the Departments of Transportation, Housing and Community Development, Environment, Business and Economic Development, and General Services.

In 2011, at the urging of Governor O'Malley, the state adopted PlanMaryland under existing statutory authority that had not been used for several decades. PlanMaryland contains information on existing development patterns and trends, overall statements and visions. The plan does not include an overall spatial vision for the state, but relies on local input to map five different kinds of planning areas and five kinds of preservation areas. PlanMaryland required state review and approval or denial of these areas and, once approved, the areas were to receive priority status under specific state agency programs (Maryland Department of Planning, 2011). However, PlanMaryland was an effort of the O'Malley administration that has not been continued under the Hogan Administration.

\subsubsection{Context Summary}

Demographic conditions, government structure, politics, and existing land use, transportation and authority provide important context for the structure of the Greenhouse Gas Reduction Act Plan. Maryland is a small, diverse state with close connections to several other Mid-Atlantic states. Maryland is well-known for innovative land use planning and environmental initiatives related to the Chesapeake Bay. The O'Malley administration provided eight years of progressive environmental leadership. The institutional structure for collaboration among state agencies is strong because of bodies like the Smart Growth Sub-Cabinet, Sustainable Growth Commission and Commission on Climate Change. In describing and assessing Maryland's approach to reducing GHG, it is important to acknowledge the strength of the governor and counties. Additionally, regional planning through MPOs is not central to Maryland's approach to reducing GHG, as all activity related to the Greenhouse Gas Reduction Act occurs at the state level.

\subsection{OREGON}

Oregon in 2007 adopted state GHG reduction goals (House Bill 3543), and in 2009 (House Bill 2001) and 2010 (Senate Bill 1059) adopted legislation requiring the state DOT to develop a Statewide Transportation Strategy for reducing GHG and also requiring or urging metropolitan areas to undertake "scenario planning” to reduce GHG from the transportation sector. Oregon's statewide land use planning program requires cities to designate urban growth boundaries (UGB) and to adopt local comprehensive plans meeting 19 Statewide Planning Goals. 


\subsubsection{Demographics}

With a population of just over 4 million and a land area of 95,988 square miles, Oregon has a density of 42.0 people per square mile, making it the $39^{\text {th }}$ densest state in the Union (U.S. Census Bureau, 2015). Notably, the eastern portion of Oregon is far less dense than the portion west of the Cascades mountain range. Oregon's population grew 12 percent from 2000 to 2010, making it the $18^{\text {th }}$ fastest growing state (U.S. Census Bureau, 2015).

\subsubsection{Government Structure}

The Oregon Legislature Assembly is sometimes referred to as a "citizen legislature" because it convenes part time and most members have other jobs (Clucas, 2009). Since Oregon voters adopted annual sessions in 2010, the legislature meets for a maximum of 160 days in oddnumbered years and 35 days in even-numbered years. Considerable political power is concentrated in the hands of the legislative leadership. Both the House speaker and the Senate president control committee assignments, appoint committee chairs, refer bills to committee, and preside over legislative debate. Of all the committees, the most powerful is the Joint Ways and Means Committee, which develops the state budget and overseas fiscal policymaking (Clucas, 2009).

The governor proposes the state budget, proposes policy, may veto legislation, and selects appointments to agencies and commissions. However, because the state is often politically divided and this is reflected in the legislature, governors often have difficulty passing policies that require legislative approval (Clucas, 2009). There is no lieutenant governor in Oregon. Four other elected officials in statewide positions also compete for the limited centralized power: the secretary of state, state treasurer, attorney general, and the Bureau of Labor and Industries commissioner (Oregon Secretary of State, 2015).

\subsubsection{Transportation Approach}

Oregon's approach to transportation planning is jointly overseen by the Oregon Department of Transportation (ODOT) and the Department of Land Conservation and Development (DLCD).

The overarching statewide plan, the Oregon Transportation Plan (OTP), sets out seven highlevel goals: 1) mobility and accessibility; 2) management of the system; 3) economic vitality; 4) sustainability; 5) safety and security; 6) funding the transportation system; and 7) coordination, communication and cooperation. Reducing GHG falls under the goal of sustainability. The plan also includes policies and strategies aimed at achieving the goals (Oregon Transportation Commission, 2006).

Under the OTP, there is a network of transportation plans adopted by various jurisdictions over different periods of time relating to different subsets of the state's overall transportation system. In general, state-level plans set policies while regional and local plans set funding priorities.

Goal 12 of Oregon's land use planning program relates to transportation. It is implemented by the Transportation Planning Rule, OAR 660-012, which calls for a network of state, regional and local transportation system plans (Oregon Administrative Rule (OAR) 660-012). 
Funding decisions are made by the Oregon Transportation Commission (OTC), which consists of five members appointed by the governor but confirmed by the Senate (Oregon Department of Transportation, 2016), 12 area commissions on transportation, eight MPOs, and stakeholder groups such as ODOT's Oregon Freight Advisory Committee (OFAC). These advise the OTC on funding priorities (Oregon Department of Transportation, 2016).

\subsubsection{Land Use Approach}

Oregon's unique approach to land use planning was established by Senate Bill 100, adopted under Gov. Tom McCall in 1973. Since then, the legislature has adopted numerous laws to refine Oregon’s approach.

The program is organized around 19 Statewide Planning Goals adopted by the Oregon Land Conservation and Development Commission (LCDC). Goal 14 (Urbanization), calls for a UGB around each city. In general, a UGB separates urban and rural land uses. Combined with Goal 14, Goal 9 (Economic Development) and Goal 10 (Housing) call for sufficient buildable land inside UGBs to meet expected industrial, commercial and residential needs for a 20-year planning period. Goal 11 (Public Facilities and Services) and Goal 12 (Transportation) call for sufficient infrastructure, especially inside UGBs, to service current and planned development. Rural uses include especially Goal 3 (Agricultural Lands) and Goal 4 (Forest Lands) uses. Goal 13 is related to energy conservation, but there is no goal specifically related to climate change. LCDC adopts administrative rules to implement the goals.

Local governments - counties and cities - are required to adopt comprehensive plans, which must be consistent with the 19 goals and acknowledged by LCDC. Periodically, local governments update parts of their comprehensive plans. More detailed land use actions_zoning, land use regulations, issuing building permits, etc.-must be consistent with adopted comprehensive plans.

\subsubsection{Context Summary}

Historically, Oregon has been a leader in statewide land use planning, with a sweeping progressive land use program adopted in the 1970s. Oregon still has one of the most stringent land use planning programs in the country and is a model for smart growth as a result. The nation's first and only elected regional government, Metro, in greater Portland, was created in 1978. Both of these developments better position Oregon to manage urban growth issues (Clucas, 2009). The LCDC shares responsibility with ODOT, and the Transportation Planning Rule was groundbreaking when passed in 1991. Recently, divisions within the legislature have undermined adoption of similar groundbreaking policies. Further, the Oregon Transportation Commission is a powerful force in transportation planning.

\subsection{WASHINGTON}

Washington in 2007 (Senate Bill 6001) and in 2008 (House Bill 2815) adopted GHG reduction limits and total VMT reduction benchmarks (Welch, 2013). Washington in 2010 released a state climate action plan entitled Path to a Low-Carbon Economy: An Interim Plan to Address Washington's Greenhouse Gas Emissions. Washington’s Growth Management Act requires local 
comprehensive plans and urban growth areas for jurisdictions that exceed a specified population or population growth rate.

\subsubsection{Demographics}

With a population of just over 7 million and an area of 71,362 square miles, Washington State has a density of 103 people per square mile, making it the 25th densest state in the United States. Notably, the eastern portion of Washington is far less dense than the western side. Washington's population has grown 14 percent in the last decade from 5.9 million in 2000 to 6.7 million in 2010, making it the 13th fastest growing state in the United States (U.S. Census Bureau, 2014).

\subsubsection{Government Structure}

Washington has a citizen legislature that operates on a "part-time” basis of 105 days in oddnumbered years following elections and 60 days in even-numbered years. Every two years the legislature is responsible for approving a budget. The budget is initially proposed by the governor, but the legislature (and more specifically, the Appropriations Committee) can control how much of the proposed budget is actually allocated. The majority leaders in both the House and the Senate hold relatively powerful positions, with the ability to assign members to committees, raise and distribute campaign funds, and chair the influential rules committee (Hodson, 2009b).

The executive branch consists of nine elected positions. These include: the governor, lieutenant governor, attorney general, secretary of state, treasurer, state auditor, superintendent of public instruction, insurance commissioner, and commissioner of public lands (Washington State Legislature, 2016).

This relatively high number of elected executives reduces the governor's power and creates more opportunities for conflict among state leaders. The governor of Washington has a moderate degree of power compared to other states. As noted above, the governor proposes the state budget to the legislature every other year for its consideration.

\subsubsection{Transportation Approach}

The Washington State Department of Transportation (WSDOT) is the steward of a multimodal transportation system and responsible for ensuring that people and goods move safely and efficiently. In addition to building, maintaining and operating the state highway system, WSDOT is responsible for the state ferry system and works in partnership with others to maintain and improve local roads, railroads and airports, as well as to support alternatives to driving such as public transportation, bicycles and pedestrian programs. The agency's 2014-2017 roadmap for Washington's transportation future, Results WSDOT, focuses on six goals: strategic investments, modal integration, environmental stewardship, organizational strength, community engagement and smart technology (Washington State Department of Transportation, 2014).

The Washington State Transportation Commission (WSTC) recommends to the legislature a comprehensive and balanced statewide transportation plan. WSTC provides a public forum for transportation policy development and reviews and assesses how the entire transportation system works across the state. The legislature makes major transportation funding decisions by adopting 
funding packages specifying projects to be constructed. Compared to other states, WSTC is relatively weak.

In January 2015, the WSTC submitted the Washington Transportation Plan 2035 (WTP2035) to the legislature. The plan is based on six policy goals established by the legislature: preservation, safety, mobility, environment, stewardship and economic vitality. Under the environment goal, WTP2035 recommends promoting bicycling and walking as viable transportation options, and making significant progress toward meeting statewide GHG reduction goals through vehicle and fuel technology, system management and operations, land use, transportation options and pricing strategies (Washington State Transportation Commission, 2015).

\subsubsection{Land Use Approach}

The Growth Management Act (GMA)-House Bill 2929 in 1990 and its implementing amendment, House Bill 1025 in 1991-was introduced to manage Washington's accelerating development and growing population. The GMA emphasizes local control and requires counties to adopt a county-wide planning policy that serve as the mandatory basis for land use regulation (League of Women Voters of Washington, 2006; Settle and Gavigan, 1993).

Twenty-nine counties are either required or have chosen to fully plan for 20 years of population growth and promote $\mathbf{1 4}$ goals: sprawl reduction; protecting property rights; concentrated urban growth; natural resource industries; affordable housing; historical lands and buildings; economic development; timely permit processing; open space and recreation; regional transportation; public facilities and services; public participation; environmental protection; and shoreline management. These counties make up about 95 percent of the state's population. The remaining 10 counties must plan for only critical areas and natural resource land (Municipal Research and Services Center, 2016; Washington State Department of Commerce, 2009).

Growth management is fundamentally a "bottom up" enterprise in Washington. While the state policies establish the goals that guide local planning, local governments identify how to implement the goals.

The state does not have approval authority over local plans: a comprehensive plan under the GMA is considered valid upon its adoption by a county. The GMA requires consistency between the county comprehensive plan and city plans (Land Use Law Center, 2007).

Growth Management Services, within the Washington Department of Commerce, provides technical assistance and education to local governments in order to encourage decisions that will meet the state's goals. Given Washington's political culture, in which collaboration is key and no one agency should have too much power, the state leads by example and provides assistance to encourage local governments to go above and beyond minimum requirements when it comes to land use planning.

The GMA also established Regional Transportation Planning Organizations (RTPOs) to allow MPOs to work together with surrounding jurisdictions to coordinate transportation planning. These RTPOs are considered the same as their respective MPOs for the purposes of the GMA. Counties are allowed to form into RTPOs voluntarily. While counties create comprehensive land use plans 
under the GMA, RTPO transportation plans do not require consistency of local government transportation plans (Washington Department of Commerce, 2008, 6).

\subsubsection{Context Summary}

Washington State's government is decentralized across state agencies and between state and local control. This tendency is apparent in the Growth Management Act, which requires local governments to set goals and establish comprehensive plans, and sets deadlines for compliance but lacks strong state oversight.

The legislature has a high degree of control over transportation spending in Washington, rather than a commission or state agency, which sometimes results in a gap between adopted policies and funding priorities. This relatively high number of elected executives reduces the governor's power.

Additionally, the legislature and governor are often split by political parties. Recently, the level of conflict has meant defeat for several new bills. As a result, Washington is left with operating under the political framework that already exists rather than relying on the legislature to pass new bills. 



\subsection{STATE APPROACHES}

States aiming to reduce GHG generally follow a consistent process: goals, efforts (i.e., plans and actions) and monitoring results (see Figure 3.1). This chapter offers a high-level summary of these three components in each state. Note that the authors produced detailed case study documents for each state, which are available by request.

A goal is a quantitative (or qualitative) statement to reduce GHG linked to climate change, or to achieve other outcomes directly linked to doing so, for example, reducing VMT.

An effort is a law, resolution, agreement, executive order, regulation, plan, policy, strategy, study, report, public investment, incentive, tax, fee, educational program, or other public-sector effort that is intended, directly or indirectly, to result in some reduction of GHG, especially from the transportation sector. States adopt climate action plans that offer potential and recommended strategies and policies for reducing GHG. States take actions to reduce GHG. Actions might include mandates, processes, incentives or financial investment. Actions capture what a state is doing to reduce GHG by reducing VMT, while plans express what the state wants to do. Actions get at the implementation piece of public policy.

Finally, a result is a measurable change in GHG, or in a closely related quantity, as well as efforts to monitor, report and respond to such measurements. Results reflect the trends in VMT and GHG over time. This section focuses explicitly on the monitoring of results rather than actual VMT or GHG levels.

\subsection{GOALS}

In 2004, the West Coast Governors’ Global Warming Initiative released a report urging California, Oregon and Washington to adopt comprehensive goals for reducing GHG (West Coast Governors' Global Warming Initiative, 2004). By 2007, California, Oregon and Washington each had adopted such goals for reducing total statewide GHG by various times to various levels compared to the 1990 base year. On the East Coast, Maryland tried but failed to pass legislation in 2007. The legislature passed the governor's Greenhouse Gas Reduction Act bill which included a goal to reduce total statewide GHG by 2020 compared to a 2006 base year.

But the four states have taken different approaches to setting targets for reducing GHG from lightduty vehicles weighing less than 10,000 pounds (Michele, 2016). Table 5.1 summarizes each state's policy choices in setting GHG reduction targets for light-duty vehicles. Each of our case study states used a different process for setting targets: California took a bottom-up approach; Oregon a top-down approach; and Washington simply legislated targets. Maryland did not establish a transportation or light-duty specific target. California and Oregon have separate targets for each MPO, whereas Washington has just statewide targets. California's and Oregon's targets are tied to GHG, allowing MPOs to achieve targets through a combination a VMT reduction and other strategies; Washington's targets are tied to VMT. California and Oregon set targets relative 
to a baseline year (2005); Washington's targets are relative to a business-as-usual projection for 2020. Finally, in California all MPOs are required to plan to meet the targets; in Oregon only the largest MPO (Portland) is required to do so; and in Washington targets don't apply at the MPO level. In California and Oregon, targets are expressed as percentage changes in per capita values; Washington established targets to reduce total VMT. By 2011, California, Oregon and Washington had adopted such targets. Maryland does not establish sector-specific targets and does not establish targets by MPO.

Table 5.2 summarizes the statewide GHG reduction goals and light-duty vehicles reduction targets. More details on each state's goals and targets are provided below.

Table 5.1: Policy Choices in Setting GHG Reduction Targets for Light-Duty Vehicles

\begin{tabular}{|c|c|c|}
\hline Question & Choice & Description \\
\hline \multirow{3}{*}{ Process? } & Legislated & Legislate targets without modeling how these relate to statewide GHG goals \\
\hline & Top-Down & Use modeling to set targets to be consistent with statewide GHG goals \\
\hline & Bottom-Up & Set targets based on what is technically / economically / politically feasible \\
\hline \multirow{2}{*}{ Geography? } & Statewide & Set a single target for entire state \\
\hline & By MPO & Set different targets for each MPO \\
\hline \multirow{2}{*}{ Quantity? } & GHG & Measure reductions in GHG as a result of local actions \\
\hline & VMT & Measure reductions in VMT \\
\hline \multirow{2}{*}{ Representation? } & Absolute & Target an absolute level to achieve \\
\hline & Relative & Target a percentage reduction from some reference \\
\hline \multirow{3}{*}{ Metric? } & Total & Measure total levels (sensitive to population changes) \\
\hline & Per Household & Measure levels per household (insensitive to population changes) \\
\hline & Per Capita & Measure levels per capita (insensitive to population changes) \\
\hline \multirow{2}{*}{ Reference? } & Baseline & Measure changes compared to a past baseline year \\
\hline & Trend & Measure changes compared to the business-as-usual trend in some future year \\
\hline \multirow{2}{*}{ Obligation? } & Mandatory & Each MPO is required to adopt a plan to meet its target \\
\hline & Voluntary & Each MPO may choose to pursue its target \\
\hline
\end{tabular}


Table 5.2: Statewide GHG Goals and Light-Duty Vehicle Targets

\begin{tabular}{|c|c|c|c|c|c|}
\hline State & Year & $\begin{array}{l}\text { Statewide } \\
\text { GHG Goals }\end{array}$ & $\begin{array}{l}\text { Light-Duty } \\
\text { Vehicle } \\
\text { Targets }\end{array}$ & $\begin{array}{c}\text { Target } \\
\text { Policy Choices }\end{array}$ & $\begin{array}{c}\text { Key } \\
\text { Legislation }\end{array}$ \\
\hline \multirow{3}{*}{ California } & 2020 & 0\% below 1990 & $\begin{array}{l}1 \% \text { above to } \\
8 \% \text { below }\end{array}$ & \multirow{3}{*}{$\begin{array}{c}\text { bottom-up } \\
\text { by MPO } \\
\text { GHG } \\
\text { relative } \\
\text { per capita } \\
\text { baseline (2005) } \\
\text { mandatory }\end{array}$} & \multirow{3}{*}{$\begin{array}{l}\text { 2005: EO S-3-05 } \\
\text { 2006: AB32 } \\
\text { 2008: SB375 } \\
\text { 2011: EO G-11-024 } \\
\text { 2015: B-30-15 }\end{array}$} \\
\hline & 2030 & 40\% below 1990 & & & \\
\hline & 2050 & 80\% below 1990 & $\begin{array}{l}1 \% \text { above to } \\
16 \% \text { below }\end{array}$ & & \\
\hline \multirow[b]{3}{*}{ Maryland } & 2020 & 25\% below 2006 & & \multirow{3}{*}{$\begin{array}{c}\text { legislated } \\
\text { statewide } \\
\text { GHG } \\
\text { relative } \\
\text { total } \\
\text { baseline (2006) } \\
\text { n/a } \\
\end{array}$} & \multirow{3}{*}{$\begin{array}{l}\text { 2007: EO 01.01.2007.07 } \\
\text { 2009: SB278 / HB315 } \\
\text { 2014: EO 01.01.2014.14 } \\
\text { 2016: SB323 / HB0610 }\end{array}$} \\
\hline & 2030 & 40\% below 2006 & & & \\
\hline & 2050 & 90\% below 2006 & & & \\
\hline \multirow[b]{3}{*}{ Oregon } & 2020 & 10\% below 1990 & & \multirow{3}{*}{$\begin{array}{c}\text { top-down } \\
\text { by MPO } \\
\text { GHG } \\
\text { relative } \\
\text { per capita } \\
\text { baseline (2005) } \\
\text { voluntary } \\
\text { (except Portland) }\end{array}$} & \multirow[b]{3}{*}{$\begin{array}{l}\text { 2007: HB3543 } \\
\text { 2009: HB2001 } \\
\text { 2010: SB1059 } \\
\text { 2011: OAR 660-044 }\end{array}$} \\
\hline & 2035 & & $17 \%$ to $21 \%$ below & & \\
\hline & 2050 & 75\% below 1990 & & & \\
\hline \multirow[b]{3}{*}{ Washington } & 2020 & 0\% below 1990 & $18 \%$ below & \multirow{3}{*}{$\begin{array}{l}\text { legislated } \\
\text { statewide } \\
\text { VMT } \\
\text { relative } \\
\text { per capita } \\
\text { trend (2020) } \\
\text { voluntary }\end{array}$} & \multirow{3}{*}{$\begin{array}{l}\text { 2007: EO 07-02 } \\
\text { 2007: SB6001 } \\
\text { 2008: HB2815 } \\
\text { 2009: EO 09-05 }\end{array}$} \\
\hline & 2035 & 25\% below 1990 & $30 \%$ below & & \\
\hline & 2050 & 50\% below 1990 & $50 \%$ below & & \\
\hline
\end{tabular}

\subsubsection{California}

In 2005, Governor Schwarzenegger issued Executive Order S-3-05, setting the goal to reduce statewide GHG by 2050 to 80 percent below 1990 levels. In 2006, the legislature passed Assembly Bill 32, the California Global Warming Solutions Act, setting the goal to reduce statewide GHG by 2020 to 1990 levels.

In 2008, the legislature passed Senate Bill 375, the Sustainable Communities and Climate Protection Act, directing the California Air Resources Board (CARB) to develop targets for each MPO to reduce GHG from light-duty vehicles as a result of local actions. In 2011, after coordinating a bottom-up effort, CARB issued Executive Order G-11-024 setting achievable targets for each of California's 18 MPOs.

\subsubsection{Maryland}

In 2007, Governor O’Malley established the Maryland Commission on Climate Change by Executive Order 01.01.2007.07. In 2007, a Global Warming Solutions bill was proposed which 
would have set targets of reduction goals of 25 percent of GHG by 2020, and a 90 percent reduction goal for 2050 did not pass.

Under the direction of the Maryland Department of Environment (MDE), the commission created the 2008 Climate Action Plan which included recommended goals for reducing GHG.

Based on these recommendations, in 2009 the Maryland Legislature passed the Greenhouse Gas Reduction Act, adopted a statutory goal to reduce GHG 25 percent from a 2006 baseline by 2020, and prepared a plan to reduce GHG by up to 90 percent from a 2006 baseline by 2050 .

In 2016, SB323 / HB0610: Greenhouse Gas Reduction Act-Reauthorization was passed by the legislature and signed by the governor. This bill extended goals to reduce GHG by 40 percent below 2006 levels by 2030 .

\subsubsection{Oregon}

In 2007, the legislature passed House Bill 3543, setting statewide GHG reduction goals exceeding those in California's AB32.

In 2009 and 2010, the legislature passed House Bill 2001, the Jobs and Transportation Act, and Senate Bill 1059, directing the LCDC to set targets for MPOs to reduce GHG from light-duty vehicles as a result of local actions. Meeting these targets, in combination with anticipated federal and state actions, would result in reductions consistent with Oregon's statewide GHG reduction goals. In 2011, LCDC adopted OAR 660-044, setting targets for each of Oregon's six MPOs (Oregon Administrative Rule (OAR) 660-044). But achieving the targets is voluntary for all but the Portland MPO.

\subsubsection{Washington}

In 2007, Governor Gregoire issued Executive Order 07-02 and the legislature passed Senate Bill 6001, setting statewide GHG reduction goals exceeding those in California's AB32.

In 2008, the legislature passed House Bill 2815, setting statewide VMT reduction targets for lightduty vehicles. Although HB2815 directs the Department of Ecology to "convene a collaborative process to develop a set of tools and best practices to assist state, regional, and local entities in making progress towards the [targets]," the statute does not impose a requirement on MPOs. Indeed, in 2013 the Washington State Court of Appeals ruled that "the current statutory framework does not require that the [Seattle MPO] adopt a transportation plan ... that achieves its proportional share of the state's goals for reducing [GHG]" (Washington State Court of Appeals, 2013).

\section{$5.2 \quad$ EFFORTS}

Although all three states started with similar statewide GHG reduction goals, each has taken a different approach to achieving those goals in the transportation sector. 


\subsubsection{California}

California's ambitious goal to reduce GHG via transportation and land use planning is unique in its scale. California delegated the responsibility for reducing GHG from the transportation sector to its MPOs. California has 18 MPOs, but just four in the largest metropolitan areas (Los Angeles, San Francisco, San Diego and Sacramento) account for 80 percent of the state's population, or over 30 million people. Each of the 18 MPOs is responsible for adopting a coordinated transportation and land use plan (Sustainable Communities Strategy, or SCS) that will reduce VMT per capita and thereby reduce GHG. Further, California passed specific legislation directing Caltrans to plan to reduce GHG and include scenarios into the 2040 California Transportation Plan to show how Caltrans will achieve maximum feasible emissions reductions to reach GHG reduction targets, as described below.

CARB anticipates that 29 percent of the total GHG reductions needed to meet California's 2020 goal will come from the transportation sector (California Air Resources Board, 2014). SB375 requires each MPO to create a SCS for achieving its GHG reduction target. While CARB sets the GHG reduction target for each MPO, the implementation strategy to achieve the target is left completely up to the MPO. SB375 is explicit in maintaining the delegation of land use authority to local governments, and thus whether an MPO will meet its GHG goal depends, in part, on its ability to coordinate with local governments to implement the SCSs.

Senate Bill 391 (2009) directs Caltrans to update the California Transportation Plan every five years to address how the state will achieve maximum feasible emissions reductions in order to meet the GHG reduction goals. SB391 specifically directs the state's transportation agencies, CalSTA and Caltrans, to reach GHG reduction goals from the transportation sector. SB391 called for Caltrans to conduct scenario planning on how the agency will meet the transportation-sector GHG reduction goal of 80 percent below 1990 levels by 2050. The 2040 California Transportation Plan will be adopted in 2016 (California Department of Transportation, 2016).

To implement SB375, California adopted several incentive and regulatory programs to encourage and compel implementation of Sustainable Communities Strategies. A CARB regulation, called the AB32 Cost of Implementation Fee Program, created a mandatory cap-and-trade program based on mandatory emissions reporting from the state's largest industrial GHG emitters. Fees collected from the cap-and-trade program are used to fund the various state agencies charged with achieving GHG reduction goals. Because transportation causes 35-40 percent of California's GHG, a large portion of funds collected from the cap-and-trade program are allocated for the implementation of SCS projects by MPOs aimed at reducing GHG from the transportation sector (Fulton, 2015). The Strategic Growth Council is the administrator of these cap-and-trade funds and is responsible for allocating them to projects that are consistent with the SCSs through its Affordable Housing and Sustainable Communities grant program. In June 2014, the California legislature passed Senate Bill 862, the Budget Act of 2014, which secured 35 percent of revenue from the cap-and-trade program for SB375 projects and the state's high-speed rail program. SB743 calls for a change in the way transportation impacts are measured in the CEQA review process. The Office of Planning and Research's (OPR) guidelines recommend using a VMT threshold to determine whether development requires CEQA review. If the development is near existing transit and VMT is expected to be low, the development can forego CEQA review, effectively streamlining and promoting infill development and decreasing statewide VMT. New CEQA criteria for 
transportation projects are meant to "promote the reduction of greenhouse gas emissions, the development of multimodal transportation networks, and a diversity of land uses” (California Public Resources Code §21099). OPR promulgated rules for SB743 implementation in 2014.

In 2011, the legislature passed SB226, which exempts certain infill development projects from CEQA review. The development project must be surrounded by 75 percent existing urban development, comply with an existing SCS, and meet density guidelines for residential development. When outside of an MPO boundary, review developments must meet the rule's definition of a "small walkable community project" to be exempt from CEQA review. Rules for SB226 were promulgated by OPR and are based off of a VMT performance measure.

\subsubsection{Maryland}

Maryland has relied on state-level plans that encompass transportation and all other sectors. The Maryland Commission Climate Change created the 2008 Climate Action Plan, which recommended goals to reduce emissions and laid the groundwork for the Greenhouse Gas Reduction Act, signed into law in 2013. The plan summarizes reductions by sector. To reach GHG reduction goals, approximately 25 percent of this reduction will come from the transportation sector, while 2.1 percent will be derived from land use (Maryland Department of Environment, 2013, 6).

The Greenhouse Gas Reduction Act Plan is the centerpiece in Maryland's approach to reducing GHG. The state relies on 150 programs and initiatives to reach these targets, but identifies 10 key programs. Only two of the key programs are transportation related: public transportation initiatives and CAFE standards. In addition to specific programs, the plan lists 55 strategies, 16 of which apply to the transportation sector. However, only five of these strategies relate to reducing VMT. Additionally, two land use programs are listed: "Reducing Emissions through Smart Growth and Land Use/Location Efficiency," and "Priority Funding Area Related Benefits" (Maryland Department of Environment 2013, 70). Maryland's approach relies on implementing existing programs and considering "enhancements" through increased regulatory authority, increased taxes, or accelerating existing plans. It is important to note that "enhancements" include aspirations

and have not yet been signed into law or adopted by the state, so the emphasis has been on plans rather than actions.

Some examples of programs addressing GHG from transportation and land use include: public transportation initiatives (transit service, ridesharing, transit-oriented development, etc.); intercity transportation initiatives (MARC and Northeast Corridor rail expansion); pricing initiatives (tolling, park and ride lots, etc.); evaluating the GHG of major transportation projects (in project selection); bike and pedestrian initiatives (bike racks, bike paths, etc.); smart growth and land use/location efficiency (smart growth programs; PlanMaryland Planning areas); and Priority Funding Areas (targeting state spending). However, new legislation or funding has not altered the existing policies and programs.

Under the Greenhouse Gas Reduction Act Plan, all of the plans, programs and initiatives are implemented at the state level. The state does not require MPOs or local governments to plan under the GHG Reduction Act. 


\subsubsection{Oregon}

HB2001 (2009) and SB1059 (2010) set Oregon's approach to reducing GHG from transportation: 1) develop a Statewide Transportation Strategy (STS) for reducing GHG from all modes, and 2) develop land use and transportation scenarios for reducing GHG from light-duty vehicles in some MPOs. Under HB2001, the Portland MPO was required to adopt and implement a transportation and land use scenario to reduce GHG. HB2001 required Eugene-Springfield (Central Lane MPO) to select a preferred scenario to reduce GHG but did not require that Central Lane MPO implement the scenario. Scenario planning is voluntary for all other MPOs.

In 2013, the Oregon Transportation Commission (OTC) "accepted" the STS, but did not formally adopt it as part of the Oregon Transportation Plan. The STS contains 18 strategies related to vehicle and engine technology advancements; fuel technology advancements; transportation options; efficient land use; and pricing, funding and markets. In 2014, the Oregon Dept. of Transportation (ODOT) detailed strategies to begin implementing the STS within two to five years. ODOT has updated several modal and topical plans to incorporate the STS (Oregon Department of Transportation, 2013).

In 2014, the Portland MPO adopted a scenario to meet its target for reducing GHG from light-duty vehicles. Implementing this scenario will require new funding to support investments in transit, bicycling and walking (Metro, 2014). In its 2015 session, the legislature tried but failed to pass a new transportation-funding package. The 2015 legislature did not address efforts to reduce GHG from transportation through scenario planning established in HB2001 and SB1059, though relevant provisions expired at the end of 2015.

As of mid-2015, no other MPOs have made significant progress towards planning for (voluntary) targets.

Oregon's land use planning program, established in 1973, is not explicitly oriented to reducing GHG. But the long-term effect of over 40 years of land use planning, in particular, the Goal 14 requirement for communities to adopt urban growth boundaries and to focus urban development inside these boundaries, has likely been to limit sprawl (compared to other states) and hence to reduce VMT compared to what it would have been otherwise.

But on the transportation side, the research team has not identified significant new state, regional or local funding directed to reduce VMT and expand other transportation options.

\subsubsection{Washington}

Washington is the first state to adopt statutory targets for reducing VMT for light-duty vehicles. HB2815 (2008) set targets for reducing statewide VMT. To achieve these targets, HB2815 directed the transportation, ecology and commerce departments to convene a collaborative process to develop tools and best practices to assist MPOs in achieving the statewide targets. HB2815 does not establish MPO-specific targets and MPOs are not required to achieve the targets. 
In 2008, Senate Bill 6580 called for a study of how Washington's Growth Management Act, first adopted in 1990, could be used or revised to address climate change. But the legislature did not adopt the recommendations.

In 2009, Governor Gregoire issued Executive Order 09-05, directing the Department of Transportation to work with the four largest MPOs (Seattle, Olympia, Vancouver and Spokane) to "cooperatively develop and adopt" regional transportation plans to achieve the VMT targets.

In 2010, the Seattle MPO adopted a RTP that includes a four-part strategy for reducing GHG from transportation: 1) build upon the VISION 2040 Regional Growth Strategy to promote compact development; 2) transition to a user fee/roadway pricing system; 3) promote multimodal transportation; and 4) recognize the role of vehicle and fuel improvements (Puget Sound Regional Council, 2010). But as noted above, HB2815 does not impose a requirement on any MPO to achieve a particular target (Washington State Court of Appeals, 2013).

In 2015, the Washington State Transportation Commission released the policy-level Washington Transportation Plan 2035. The plan recommends promoting bicycling and walking as viable transportation options, and making significant progress toward meeting statewide GHG reduction goals through vehicle and fuel technology, system management and operations, land use, transportation options, and pricing strategies (Washington State Transportation Commission, 2015).

Washington's Commute Trip Reduction program aims to reduce drive-alone commute trips through employer-based programs. When first adopted in 1991, it aimed to improve air quality, reduce traffic congestion, and reduce fuel consumption; now it has the added result of reducing GHG.

While Washington has created several plans and studies, the state has not taken actions in the form of new policies or programs to achieve GHG and VMT reduction goals.

\subsection{MONITORING}

Monitoring relates to how states measure progress towards achieving results. Each state has a unique approach to monitoring. Some state legislatures require interim reports while others simply requiring tracking GHG or VMT.

\subsubsection{California}

California's approach requires a certain degree of monitoring. AB32 requires that CARB update a Scoping Plan every five years that evaluates progress and identifies strategies for reaching GHG reduction goals. Related to transportation and land use planning, SB375 requires the updating of targets every eight years and plans every four years. Although CARB reviews and accepts SCSs under SB375, the statutes do not require CARB or other agencies to monitor and evaluate the implementation of SCSs. While MPOs update regional transportation plans (RTPs) and SCSs every four years, there is not a systematic approach to monitoring the implementation of SCSs. 
The May 2014 First Update Scoping Plan presents key accomplishments made by California thus far in reducing GHG from all sectors, including transportation, which saw an overall decrease of 1.7 percent from 2000 to 2012 (California Air Resources Board, 2014). While these reductions are partly attributable to decreased driving concurrent with the Great Recession, the continued decrease in GHG from the transportation sector since its 2005 peak is poised to continue. A nearly 11 percent decrease in GHG from the transportation sector between 2000 and 2012 points towards early success in achieving the state's ambitious overall GHG reduction goals.

\subsubsection{Maryland}

Per statute, MDE is required to review and publish an updated GHG inventory for 2011 and every third calendar year after. By October 1, 2015, MDE was required to submit a status report to the governor and General Assembly on implementation of the GHG Reduction Act Plan. Statutes related to the Greenhouse Gas Reduction Act Plan are only in effect until December 31, 2016, meaning the bill would sunset at the end of 2016 if the legislature does not take action. As described above, the legislature extended the Greenhouse Gas Reduction Act Plan in the 2016 session.

MDE released the 2015 Greenhouse Gas Reduction Act Plan Update per mandate. The update summarizes progress towards reaching 2020 emissions reduction goals. The emissions targets were evaluated as part of the plan update. As a result, the 2020 Goal was reduced to 34.66 $\mathrm{MMtCO}_{2} \mathrm{e}$, which is significantly less than the $55.26 \mathrm{MMtCO}_{2} \mathrm{e}$ goal articulated in the 2013 plan. Market force reductions reflect the $20.60 \mathrm{MMtCO}_{2} \mathrm{e}$ decrease in the goal, reflecting a shift in energy sources, the economic downturn, and overestimated VMT estimates in 2012. The 2015 Greenhouse Gas Reduction Act Plan Update showed that the state is on track to exceed the 2020 emissions target, generating $38.37 \mathrm{MMtCO}_{2} \mathrm{e}$ of reductions, exceeding the goal of 34.66 $\mathrm{MMtCO}_{2}$ e. Transportation is responsible for 28 percent of the reductions. Of that share, the initiatives related to VMT (public transportation, pricing initiatives and other innovative transportation strategies/programs) constitute 10 percent of reductions. Land use initiatives constitute approximately 1.5 percent of reductions (Maryland Department of Environment, 2015). The Greenhouse Gas Reduction Act Plan Update recommended continuing to implement and enhance the programs while adopting incremental progress toward further reductions by 2050 .

\subsubsection{Oregon}

Under HB3543 (2007), the Oregon Global Warming Commission (OGWC) is required to report biennially on progress in achieving the GHG reduction goals. In 2010, OGWC adopted an interim plan to achieve Oregon's goals for 2020. But as HB3543 gave OGWC no statutory authority, this plan does not set state policy (Oregon Global Warming Commission, 2010). The 2013 OGWC progress report concludes that "Oregon is not on track" to meet its 2020 goal (Oregon Global Warming Commission, 2013). The report relies, in part, on a detailed biennial inventory of Oregon's GHG (Oregon Departments of Environmental Quality, Energy and Transportation, 2013). 


\subsubsection{Washington}

Under HB2815 (2008), the Departments of Ecology and Commerce are required to report biennially on Washington's GHG. The latest report indicates a decrease in GHG from the transportation sector, but attributes this to a weak economy. The report does not compare the progress to Washington's GHG reduction goals (Washington State Department of Ecology, 2014). 


\subsection{SYNTHESIS}

Each case study state has taken a different approach in leadership, establishing a policy framework, setting goals, assigning planning roles for state and regional agencies, implementation, and monitoring. This section synthesizes case study information described above to highlight key similarities and differences. These are organized into the themes described in Section 3.4 above: leadership, policy framework, goals, planning, implementation and monitoring. Note that institutional relationships and regional and local support are not addressed in this section but are in later sections. See Tables 6.1 and 6.2.

Table 6.1: Leadership, Policy Framework and Goals by State

\begin{tabular}{|c|c|c|c|}
\hline State & Leadership & Policy Framework & Goals \\
\hline California & $\begin{array}{l}\text { - Originated from } \\
\text { governors }\end{array}$ & $\begin{array}{l}\text { - Sustainable Community Strategy } \\
\text { (SCS): Assign target for each MPO } \\
\text { to meet }\end{array}$ & $\begin{array}{l}\text { - } \text { Overall goal in statute } \\
\text { - } \text { Transportation specific } \\
\text { targets (passenger) }\end{array}$ \\
\hline Maryland & $\begin{array}{l}\text { - Originated from } \\
\text { governor with strong } \\
\text { authority }\end{array}$ & $\begin{array}{l}\text { - Climate Change Commission } \\
\text { - Takes a state level approach - how } \\
\text { far can we get? }\end{array}$ & $\begin{array}{l}\text { - Overall goal in statute } \\
\text { - No transportation } \\
\text { specific targets }\end{array}$ \\
\hline Oregon & $\begin{array}{ll} & \text { Initial legislation } \\
& \text { originated from } \\
& \text { governor } \\
\text { - } & \text { WCGGWI influenced } \\
\text { - } & \text { Interest groups pushed } \\
& \text { original legislation } \\
\end{array}$ & $\begin{array}{l}\text { - MPO level targets but only two } \\
\text { MPOs have responsibilities }\end{array}$ & $\begin{array}{l}\text { - } \text { Overall goal in statute } \\
\text { - } \text { Transportation specific } \\
\text { targets (passenger) }\end{array}$ \\
\hline Washington & $\begin{array}{l}\text { - Originated from } \\
\text { governor } \\
\text { - } \text { WCGGWI influenced } \\
\end{array}$ & - Shared governance & $\begin{array}{l}\text { - Overall goal in statute } \\
\text { - Total VMT targets in } \\
\text { statute }\end{array}$ \\
\hline
\end{tabular}

\subsection{LEADERSHIP}

This subsection summarizes case study information related to motivation, vision and (executive) leadership.

Collaboration through the West Coast Governors' Global Warming Initiative (WCGGWI) was influential in establishing policy in West Coast states, especially Oregon and Washington. In all states, governors influenced initial legislation to establish GHG reduction goals. However, consistent leadership from the governor was more influential in California, Maryland and Washington, where executive orders laid the groundwork for later legislation in all states. In Oregon, neither the governor nor legislators but rather environmental advocacy groups pushed to include provisions related to reducing GHG into the 2009 transportation funding package (HB2001), so the executive and legislative branches did not exert leadership or ownership over the approach. 


\subsection{POLICY FRAMEWORK}

The policy framework used by states describes where policy originated and how states attempt to reduce GHG from transportation.

Just as origination of policy varied, the general approach varied across states as well. The policies by which these states plan to reduce GHG vary significantly. California and Oregon set a different target for each MPO and delegate each responsibility for developing strategies to reduce GHG from transportation. California and Oregon rely on transportation and land use scenario planning, although only California requires all MPOs to participate. Washington is unique in establishing VMT targets.

California relies on Sustainable Community Strategies that require all MPOs to reach per capita targets or adopt an Alternative Planning Strategy. California relies on using a performance metric to guide planning and allowed MPOs flexibility in reaching targets. Rather than mandating that MPOs implement specific policies or programs, MPOs were granted flexibility in deciding how to reach targets through a combination of transportation and land use strategies.

Oregon also relies on regional targets and MPOs, but only two MPOs (Portland and Eugene) are required to undertake scenario planning and only one MPO (Portland) must adopt a plan to reach the target. The policy framework in Washington has varied over time, but shared governance across agencies has been consistent. Maryland focuses efforts at the state level and relies on a Climate Change Commission.

\subsection{GOALS}

Goals are important because they provide a sense for how much states seek to reduce GHG and the time frame for achieving such reductions. States differ in establishing goals through the baseline, target year, percentage reduction, and whether goals reflect all emissions or transportation. California, Oregon and Washington established ambitious statutory targets for reducing total GHG from transportation or VMT.

In all states, goals were first established by executive order then codified after later receiving legislative approval. The goals vary across states, but all of these states seek to reduce statewide GHG by 50-80 percent below a 1990 baseline by 2050. However, as Wheeler (2008) concluded in describing first-generation climate action plans, the shorter-term goals are still conservative. Washington and California seek to reach 1990 levels by 2020, while Oregon seeks a 10 percent reduction below 1990 levels and Maryland seeks to reduce GHG 20 percent below 2006 levels by 2020.

Currently, all states have 2020 goals in statute. Maryland and California established short-range (2020) goals initially while Washington and Oregon established multiple goal years with a single piece of legislation. Maryland was unique in establishing a sunset provision, which required the legislature to take action on further goals, and in 2016, the governor signed a 2030 target into law. 
California, Oregon and Washington establish transportation-specific targets. California and Oregon establish per capita targets for light-duty vehicles for each MPO. Washington establishes total VMT targets at the state level.

Table 6.2: Planning, Implementation and Monitoring by State

\begin{tabular}{|c|c|c|c|c|}
\hline State & State Planning & Regional Planning & Implementation & Monitoring \\
\hline California & $\begin{array}{l}\text { - CARB oversees } \\
\text { - Scoping plan (all } \\
\text { sectors) } \\
\text { - Updated LRTP } \\
\text { - No state land use } \\
\text { planning but } \\
\text { guidance for local } \\
\text { plans }\end{array}$ & $\begin{array}{ll}\text { - } & \text { MPOs responsible } \\
\text { - } & \text { SCS/RTP } \\
& \text { integration } \\
\text { - } & \text { All required }\end{array}$ & $\begin{array}{l}\text { - } \text { Cap-and-trade } \\
\text { funding } \\
\text { - Regulatory relief } \\
\text { - High-speed rail } \\
\text { - } \text { Difficult to balance } \\
\text { maintenance and } \\
\text { expansion } \\
\text { - Not enough } \\
\text { funding to } \\
\text { implement SCSs } \\
\end{array}$ & $\begin{array}{ll}\text { - } & \text { Revision of } \\
\text { targets required } \\
\text { - } & \text { Tracking GHG } \\
\text { - } & \text { Lack of } \\
\text { monitoring of } \\
\text { plans } \\
\text { - No feedback loop } \\
\text { from GHG to } \\
\text { policies }\end{array}$ \\
\hline Maryland & $\begin{array}{l}\text { - } \text { MDE oversees } \\
\text { - } 2 \text { climate plans - } \\
\text { before statute and } \\
\text { after statute } \\
\text { - } \text { LRTP references } \\
\text { GHG } \\
\text { - } \text { State development } \\
\text { plan } \\
\text { (PlanMaryland } \\
\text { (but no longer in } \\
\text { effect) }\end{array}$ & $\begin{array}{l}\text { - } \begin{array}{l}\text { Not required to be } \\
\text { engaged }\end{array} \\
\text { - Action by MPOs is } \\
\text { voluntary-both } \\
\text { Baltimore and } \\
\text { Washington, D.C., } \\
\text { are involved }\end{array}$ & $\begin{array}{l}\text { - All mechanisms in } \\
\text { place before } \\
\text { climate programs } \\
\text { - Enhancements in } \\
\text { GHG Reduction } \\
\text { Act Plan go above } \\
\text { and beyond } \\
\text { existing policies } \\
\text { - Need funding to } \\
\text { expand } \\
\text { transportation } \\
\text { options } \\
\end{array}$ & $\begin{array}{l}\text { - Regular reports } \\
\text { on GHG } \\
\text { - } \text { Requirement for } \\
2015 \text { report on } \\
\text { implementation }\end{array}$ \\
\hline Oregon & $\begin{array}{ll}\text { - } & \text { No one agency } \\
\text { has ownership } \\
\text { - OGWC plan } \\
\text { (advisory) } \\
\text { - ODOT climate } \\
\text { plan (advisory) } \\
\text { - No update to } \\
\text { LRTP } \\
\text { - UGBs predate } \\
\text { GHG }\end{array}$ & $\begin{array}{l}\text { MPOs responsible, } \\
\text { but only Portland } \\
\text { and Eugene required } \\
\text { to do scenario } \\
\text { planning and only } \\
\text { Portland required to } \\
\text { adopt }\end{array}$ & $\begin{array}{l}\text { - All mechanisms in } \\
\text { place before } \\
\text { climate programs } \\
\text { (UGB) } \\
\text { - Need funding to } \\
\text { implement plans } \\
\text { (transit) }\end{array}$ & $\begin{array}{ll}\text { - } & \text { Revision of } \\
\text { targets required } \\
\text { - } & \text { OGWC biennial } \\
& \text { report card } \\
\text { - } & \text { Lack of } \\
\text { monitoring of } \\
\text { scenarios. }\end{array}$ \\
\hline Washington & $\begin{array}{ll}\text { - } & \text { Distributed } \\
& \text { authority } \\
\text { - } & \text { Climate action } \\
\text { plan } \\
\text { - Updated LRTP } \\
\text { - Studies on growth } \\
\text { management and } \\
\text { climate change }\end{array}$ & $\begin{array}{ll}\text { - } & \text { MPOs not required } \\
\text { to be engaged } \\
\text { (lawsuit) } \\
\text { - } \\
\text { Seattle MPO } \\
\text { (PSRC) voluntarily }\end{array}$ & $\begin{array}{l}\text { All mechanisms in } \\
\text { place before } \\
\text { climate programs } \\
\text { (GM) } \\
\text { - Expansion of mass } \\
\text { transit (but } \\
\text { independent of } \\
\text { climate goals) } \\
\text { - WSDOT engaged } \\
\text { in Practical } \\
\text { Solutions and } \\
\text { Corridor Planning } \\
\text { - Need funding to } \\
\text { implement plans }\end{array}$ & $\begin{array}{ll}\text { - } & \text { Tracking levels of } \\
\text { GHG } \\
\text { - No requirement } \\
\text { to meet target }\end{array}$ \\
\hline
\end{tabular}




\subsection{STATE PLANNING}

State planning is an important element in all states as the statutes emerged from state government, even if implementation occurs by state or local governments. The role of the state transportation plan, the agency providing oversight, and coordination across state agencies has varied. In some states, one agency leads while efforts are more collaborative in other states.

Maryland was unique in publishing a state development plan, long-range transportation plan and GHG plan in close succession such that documents include cross-references. Since transportationspecific legislation was adopted, California and Washington were the only states to update longrange transportation plans (LRTPs). Oregon created the STS and Implementation Plan and has updated modal plans to be consistent with the STS, but it is unclear to what extent these plans guide investments, as they were "accepted" by the Oregon Transportation Commission but not adopted as part of the LRTP. California is the only state that requires its DOT to illustrate how the LRTP reaches a specific GHG target. In Washington, several studies have been commissioned by the legislature related to coordinating state agencies in efforts to reduce GHG, but little policy has emerged from these studies.

The agency leading efforts varies considerably across states and accountability varies as a result. In California, the powerful regulatory Air Resources Board was put in charge of establishing targets and reviewing SCSs. In Maryland, a Climate Change Commission was established to lay the groundwork and offer reports, but the Maryland Department of Environment coordinated the creation of the Greenhouse Gas Reduction Act Plan (Maryland Department of Environment, 2013). In Oregon, the transportation and land use agencies jointly established targets which were then adopted by the Land Conservation and Development Commission. In Washington, authority was distributed across several agencies with no agency bearing primary responsibility. In all cases, the transportation agency was not granted the primary role in developing or overseeing key plans.

Relying on state DOTs to reduce GHG is difficult because of the institutional culture and focus of DOTs. Reducing GHG from VMT requires shifts in transportation pricing, increasing transportation options and compact development. State DOTs do not have the authority to impose new taxes to raise the price of driving, and sometimes lack the authority to shift funding from roads to alternative modes. Further, policies encouraging compact development must emerge from the local level rather than state DOTs. This disconnect makes it difficult to hold DOTs accountable for reducing GHG from transportation despite legislative requirements for DOTs to plan for reducing GHG from transportation at the state level in Oregon and California.

Because one strategy for reducing VMT relies on compact development, having state-level growth management programs set the states up for success in making progress towards goals. In Oregon and Washington, long-standing, state-level growth management programs were a key strength. In Maryland, the state development plan held promise for relying on land use planning to reduce GHG from transportation, but efforts were abandoned when a new governor was elected. In California, the lack of state-level growth management is a key obstacle in making progress towards goals. 


\subsection{REGIONAL PLANNING}

California and Oregon delegate some responsibility for reaching GHG reduction goals to MPOs. In Washington, HB2815 establishes statewide targets, but these are voluntary at the metropolitan and local levels (Washington State Court of Appeals, 2013). California requires all MPOs to create SCSs and integrate SCSs with RTPs. In Oregon, only the Portland and Eugene MPOs were required to conduct scenario planning, and only the Portland MPO was required to adopt and implement the preferred scenario. Thus, comprehensiveness varies across states.

In California and Oregon, MPOs were a logical focus for undertaking planning. But California's MPOs and the Portland MPO have more authority than typical. In California, models improved and plans were better coordinated as a result of the requirements of SB375. In Oregon, requiring Portland to adopt a plan and making the process voluntary for other MPOs was an effective way to provide an example to other MPOs and show that goals could be met by implementing current plans. But, this means that progress in Oregon has been confined to the Portland area. While the Eugene and Corvallis MPOs have taken some steps, neither has adopted a plan for reducing GHG from transportation. Though all MPOs in California must participate, the process does not adequately recognize that MPOs vary in planning capacity. Further, because MPO boards are controlled by local officials, gaining buy-in from some MPOs has been challenging. This is particularly problematic in California where county transportation boards have great sway on project selection. In both California and Oregon, several stakeholders described how there was not enough funding set aside for planning. In Washington, there is no comprehensive approach to addressing GHG in metropolitan plans, and only the Seattle MPO (PSRC) has voluntarily embedded reducing GHG into its plans. In Maryland, all action for MPOs is voluntary. MPOs have not been involved in the creation or implementation of the GHG Reduction Act Plan and do not serve on the Climate Change Commission.

\subsection{IMPLEMENTATION}

Implementation mechanisms adopted by states have varied considerably. Only California has adopted new legislation and policies aimed at implementing SB375. In Oregon and Washington, programs that predate GHG legislation like Oregon's urban growth boundaries (UGBs) and Washington's Commute Trip Reduction serve as key elements in the approach. In Maryland, preexisting programs were used to determine how much reduction could be achieved through existing programs while enhancements offered information about implementing new programs. In Oregon, Portland's Climate Smart Strategy found that implementing existing transportation plans would achieve the GHG reduction targets, but there is insufficient funding to do so.

Unrelated to GHG legislation, Washington is making investments in mass transit expansion. California is investing in high-speed rail and offering competitive funding for SB375 implementation through cap-and-trade funds. However, the lack of funding was overwhelmingly the most discussed obstacle in all states. Even in states making investments, there was not enough funding, funding sources are often constrained, and states and MPOs must balance needs for maintenance with expansion of transit. In California, some jurisdictions have changed the transportation project prioritization process, but overall, there seems to be a time lag in shifting RTP funding, likely owing to the sometimes decades-long project time frame in transportation planning. 


\subsection{MONITORING}

All states rely on tracking the levels of GHG and VMT to monitor progress towards goals. California and Oregon require reports that evaluate progress towards goals and describe implementation mechanisms like policies, programs and incentives. Both California and Oregon revise targets on a periodic basis. California is unique in requiring periodic updates of MPO plans to reduce GHG from transportation. Maryland required an interim legislative report prior to extending the Greenhouse Gas Reduction Act Plan. Washington develops regular GHG inventories, but there is no requirement to describe policy implementation to the legislature or executive on an ongoing basis. Often GHG tracking occurs within an environmental agency while the actions that affect GHG emerge from state, regional and local transportation agencies. While states are generally on track to reach 2020 goals, progress to date is partially attributed to high gas prices and high unemployment during the Great Recession. Recent VMT data raise questions about the longevity of recent trends (U.S. Federal Highway Administration, 2015).

Though states are tracking levels of GHG and VMT, states are not monitoring the implementation of plans to examine whether policies and programs are having their intended effects and whether transportation choices and land use patterns are shifting as a result. No state has a comprehensive, consistent monitoring program in place. In California, CARB is a strong agency and is given responsibility for approving SCS plans, but has no role in tracking implementation. MPOs have to show that adopted plans will meet targets (unless the MPO adopts Alternative Planning Strategies), but are not held accountable for actually reaching the targets. In Maryland, a legislatively mandated 2015 report provided a strong evaluation of implementation to date, but comprehensive reporting is not consistent (Maryland Department of Environment, 2016). In Oregon, OGWC publishes biennial report cards but has no real oversight or authority. In Washington, state agencies are required to report biennially on GHG. 


\subsection{STAKEHOLDER EVALUATIONS}

In stakeholder interviews, we asked synthesis questions on each state's overall approach to reducing GHG. 1) What do you consider to be the obstacles to reducing GHG from the transportation sector in your state? 2) What are the strengths and weaknesses of your state's overall approach to reducing GHG, specifically in the transportation sector? We asked these as openended questions and synthesized based on common topic areas.

This section summarizes what stakeholders reported as the strengths and weaknesses of each state's approach. These are organized into the themes described in Section 3.4 above: leadership, policy framework, planning, institutional relationships, implementation and monitoring. Note that stakeholders did not report any strengths or weaknesses related to goals or to regional and local support.

\subsection{LEADERSHIP}

This subsection summarizes what stakeholders reported as strengths and weaknesses related to motivation, vision and (executive) leadership. See Table 7.1.

Table 7.1: Leadership Strengths and Weaknesses

\begin{tabular}{|c|c|c|}
\hline State & Strengths & Weaknesses \\
\hline California & $\begin{array}{l}\text { - Progressive executive leadership } \\
\text { - CARB }\end{array}$ & - Lack of big-picture vision \\
\hline Maryland & $\begin{array}{l}\text { - Gov. O’Malley provided strong } \\
\text { leadership for eight years }\end{array}$ & $\begin{array}{l}\text { - Strong governor state means that shifts occur } \\
\text { when leadership changes }\end{array}$ \\
\hline Oregon & - $\mathrm{n} / \mathrm{a}$ & $\begin{array}{l}\text { - Lack of gubernatorial leadership and legislative } \\
\text { support }\end{array}$ \\
\hline Washington & - Progressive executive leadership & - Different governors focus on different policies \\
\hline
\end{tabular}

\subsubsection{Strengths}

Leadership from the executive was seen as a key strength in some states, but not all. Because policies emerged differently in each state, the governor played a variable role. In California and Maryland, governors were instrumental in pushing legislation. In Washington, progressive executive leadership was seen as a key strength. Governor Inslee is particularly active in climate legislation. In Oregon, gubernatorial leadership was not seen as a key strength. This was because policies emerged from nonprofit groups rather than the executive branch.

\subsubsection{Weaknesses}

Across all states, the inconsistency in gubernatorial leadership and shift in vision across gubernatorial administrations has undermined effectiveness. Each new governor comes in to office and wishes to establish his/her own legacy. This was particularly true in California, Maryland and Washington, where stakeholders described the lack of consistent leadership as a key issue. 
Stakeholders in each state desired stronger leadership. In California, the lack of a big-picture vision was seen as a weakness. In Oregon, because the governor and legislature did not propose policies and because of turnover in leadership, no one in the legislative or executive branch seems to be paying attention. In Maryland, the strength of the governor meant that transitions were difficult to anticipate when leadership changes. The shift from O’Malley (who was a strong climate governor) to Hogan (a Republican with an unknown record) was particularly challenging to anticipate. In Washington, there has been an ongoing cycle of the executive proposing and the legislature declining to act.

\subsection{POLICY FRAMEWORK}

This subsection summarizes what stakeholders reported as strengths and weaknesses related to aspects of the policy framework, or how key legislation is structured. See Table 7.2.

Table 7.2: Policy Framework Strengths and Weaknesses

\begin{tabular}{|c|c|c|}
\hline State & Strengths & Weaknesses \\
\hline California & $\begin{array}{l}\text { - Incremental approach } \\
\text { - Performance driven } \\
\text { - ARB oversees } \\
\text { - Comprehensive across all sectors }\end{array}$ & $\begin{array}{l}\text { - Not regulatory in ensuring that MPOs reach } \\
\text { targets (only that MPOs adopt SCSs that aspire } \\
\text { to reach targets) }\end{array}$ \\
\hline Maryland & $\begin{array}{l}\text { - Climate Change Commission } \\
\text { - Comprehensive }\end{array}$ & $\begin{array}{l}\text { - VMT not cost effective } \\
\text { - Short time frame to produce two reports (sunset } \\
\text { rule) } \\
\text { - Difficult to achieve transportation and land use } \\
\text { goals in short time frame } \\
\text { - MDOT needs a reason to say no } \\
\end{array}$ \\
\hline Oregon & $\begin{array}{l}\text { - Portland going first to show other } \\
\text { regions can achieve } \\
\text { - State land use }\end{array}$ & $\begin{array}{l}\text { - Overreliance on plans } \\
\text { - Not comprehensive approach }\end{array}$ \\
\hline Washington & - Growth Management Act & $\begin{array}{l}\text { - No performance responsibility assigned to state } \\
\text { agencies and regions }\end{array}$ \\
\hline
\end{tabular}

\subsubsection{Strengths}

Stakeholders in each state described key strengths in the overall policy framework. In California and Maryland, the comprehensive approach to considering all sectors of emissions was noted as a key strength. In Oregon and Washington, statewide land use planning, which predates climate planning, was noted as a key strength. In California and Maryland, the agency or body in charge of oversight was seen as a key strength. In California CARB oversees SB375, while in Maryland the Climate Change Commission provides oversight. Unique to California, the performancedriven, incremental approach was seen as a key strength. Providing MPOs with a target and offering flexibility for how MPOs reach that target was seen as effective. In Oregon, requiring Portland to be the first MPO to plan to reduce targets was seen as a way to show other regions that transportation targets are achievable without changing existing land use plans.

\subsubsection{Weaknesses}

Weaknesses in the policy framework varied across states. In California, the lack of a regulatory framework for reducing GHG was seen as a weakness. In Maryland, the short time frame to reach 
the 2020 goal and produce a report meant focusing on "low-hanging fruit.” As a result, VMT and reducing GHG from transportation was not seen as effective. Requiring two reports in a short time frame was also a weakness. Finally, MDOT needs a reason to say no to projects if it increases GHG and currently does not have such authority. In Oregon, the overreliance on plans was a key weakness. The policy framework was also seen as weak in Oregon because of the lack of an adopted comprehensive plan to reduce GHG from all sectors. In Washington, not assigning performance responsibility to state agencies or regions (but rather relying on decentralized leadership) was seen as a key weakness.

\subsection{PLANNING}

This subsection summarizes what stakeholders reported as strengths and weaknesses related to aspects of state, regional and local planning processes. See Table 7.3.

Table 7.3: Planning Strengths and Weaknesses

\begin{tabular}{|c|c|c|}
\hline State & Strengths & Weaknesses \\
\hline California & $\begin{array}{l}\text { - Modeling strong } \\
\text { - Climate and transportation integrated at state } \\
\text { level }\end{array}$ & $\begin{array}{l}\text { - Need funding for modeling } \\
\text { - Small MPOs need funding and technical } \\
\text { support } \\
\text { - Big emphasis on assumptions being } \\
\text { accurate }\end{array}$ \\
\hline Maryland & $\begin{array}{l}\text { - Modeling strong } \\
\text { - Land use/climate/transportation integrated on } \\
\text { paper }\end{array}$ & - $\mathrm{n} / \mathrm{a}$ \\
\hline Oregon & $\begin{array}{l}\text { - Modeling in Portland strong } \\
\text { - Integration of transportation/land use }\end{array}$ & $\begin{array}{l}\text { - Only MPOs modeling } \\
\text { - Lack of funding and technical support } \\
\text { for small MPOs }\end{array}$ \\
\hline Washington & $\begin{array}{l}\text { - Integration of transportation/land use, } \\
\text { especially at PSRC }\end{array}$ & - $\mathrm{n} / \mathrm{a}$ \\
\hline
\end{tabular}

\subsubsection{Strengths}

Planning for climate change by reducing GHG requires sophisticated modeling to examine how various policy scenarios might reduce GHG. Because MPOs are asked to reach targets in California and Oregon, modeling infrastructure is particularly important. As a result, modeling infrastructure was seen as a key strength in California, Oregon and Washington. Maryland's comprehensive approach also relies on heavy modeling.

Another key area of strength focuses on integration of transportation, land use and climate change plans. In California, transportation and climate change plans were well integrated at the state level. In Maryland, transportation, land use and climate change plans were well-integrated at the state level because the state updated all three plans close in time. However, the land use plan (PlanMaryland) is no longer in effect after a transition to a new administration. In Oregon, transportation and land use are integrated at the state level because of policies that pre-date climate change legislation: the Statewide Planning Program and the Transportation Planning Rule. In Washington, transportation and land use are well-integrated in the Puget Sound Regional Council, but not at the state level. 


\subsubsection{Weaknesses}

While modeling has improved across California and Oregon, larger MPOs are better able to support expensive modeling efforts. In both California and Oregon, there is a lack of financial and technical support for modeling in smaller MPOs. Additionally, there is a large emphasis on assumptions that may or may not be accurate. Transportation planning to reduce GHG is dependent on models of future demand, congestion and VMT. Though models are increasingly sophisticated, there is often very little ex post evaluation of models to test whether assumptions were correct.

\subsection{INSTITUTIONAL RELATIONSHIPS}

This subsection summarizes what stakeholders reported as strengths and weaknesses related to the relationships between state regional and local agencies, focusing on horizontal relationships among agencies at the same level and vertical relationships between levels. See Table 7.4.

Table 7.4: Institutional Relationships Strengths and Weaknesses

\begin{tabular}{|c|c|c|}
\hline State & Strengths & Weaknesses \\
\hline California & - Horizontal collaboration among agencies in strong & $\begin{array}{l}\text { - MPO/agency connection weak } \\
\text { - Local control over land use } \\
\text { - Hard to work with neighboring } \\
\text { MPOs } \\
\text { - Strategic Growth Council } \\
\text { understaffed }\end{array}$ \\
\hline Maryland & $\begin{array}{l}\text { - Climate Change Commission, Smart Growth } \\
\text { Subcabinet, Sustainable Growth Commission - } \\
\text { horizontal coordination on paper }\end{array}$ & $\begin{array}{l}\text { - MDOT hard to work with } \\
\text { - No vertical integration } \\
\text { - Interagency coordination weak }\end{array}$ \\
\hline Oregon & - $\mathrm{n} / \mathrm{a}$ & $\begin{array}{l}\text { - Lack of authority, responsibility } \\
\text { - ODOT hard to work with }\end{array}$ \\
\hline Washington & - Collaboration because of decentralized structure & - No one responsible \\
\hline
\end{tabular}

\subsubsection{Strengths}

Horizontal relationships were strong in California and Maryland. California established the Strategic Growth Council to coordinate state agencies. In Maryland, horizontal structure was very strong on structure because of formal organizations like the Smart Growth SubCabinet, Sustainable Growth Commission and Climate Change Commission that include representatives from state agencies and other stakeholders. In California, stakeholders noted that horizontal barriers were broken down at the state level because of SB375. After transportation-specific legislation went into effect, some California stakeholders noted improved coordination among state agencies and described a shift of culture in the state DOT related to an increased focus on GHG. Horizontal coordination was not seen as very strong in Oregon and Washington. However, the decentralized nature of policy translated to coordination in Washington. Stakeholders also described improved communication among state agencies. In Oregon, the ties between transportation and land use were seen as key strengths.

Vertical relationships were described by some stakeholders as well. In California, stakeholders described coordination and communication as key strengths of the California approach. As described by stakeholders, improved collaboration across MPOs and between the MPOs and the 
state occurred as a result. In Washington, additionally, stakeholders remarked on a notable improvement in the relationships between state and local agency communication and coordination.

\subsubsection{Weaknesses}

Horizontal coordination was not always seen as strong in states, even when organizations were established for the explicit purpose of horizontal coordination as in California and Maryland. In California, stakeholders noted issues with horizontal coordination among state agencies in which efforts are not always synchronized. While California established the Strategic Growth Council to encourage horizontal coordination, the coordination has not always trickled down within agencies. The tasks assigned to SGC in allocating cap-and-trade funding exceed their capacity, raising questions about how to get the money out the door.

In Maryland, the lack of interagency coordination was discussed by one stakeholder. Additionally, one stakeholder questioned the effectiveness and impact of the Sustainable Growth Commission since the chair is appointed by the governor. Although the structure of coordination looks good on paper in Maryland, several stakeholders noted that it does not lead to better coordination of policies in practice. In Oregon, stakeholders described the challenge of coordinating and integrating across sectors as a key shortcoming. Further, stakeholders described how the lack of authority and responsibility to a single agency represented key shortcomings.

Beyond horizontal coordination, the nature and role of transportation agencies was identified as a key weakness of institutional relationships in several states. Shifting the culture of transportation agencies is slow. Other state agencies charged with overseeing or collaborating in plans and efforts to reduce GHG note challenges in shifting the focus of DOTs. Stakeholders in California, Maryland and Oregon described the challenge of working with a transportation agency to reduce GHG as challenging because the key mission of transportation agencies focuses on efficient movement of goods and people rather than reducing GHG. In Washington, stakeholders described challenges in horizontal coordination among state agencies, noting how the distribution of authority across agencies made it difficult for agencies to take ownership over policies.

Vertical coordination was seen as weak in several states. In California, the lack of statewide land use planning and local control of land use were seen as key weaknesses in the overall approach. Some aspects of MPOs present obstacles in California. Specifically, not all regions are all on board, there are issues in dealing with adjacent MPOs and working together.

In Maryland, stakeholders discussed the limited authority of MPOs as a key weakness. Further, the strength of counties undermined state level approaches. In Washington, stakeholders described challenges in vertical coordination between state agencies and RTPOs, in which a lack of communication means that RTPOs are unaware of state policy related to GHG targets. Local relationships were also challenging in Washington, where local authority over transportation planning with little state involvement was seen as a weakness. 


\subsection{IMPLEMENTATION}

This subsection summarizes what stakeholders reported as strengths and weaknesses related to aspects of implementing plans, strategies and policies. Implementation varied considerably across states. See Table 7.5.

Table 7.5: Implementation Strengths and Weaknesses

\begin{tabular}{|l|l|l|}
\multicolumn{1}{|c|}{ State } & \multicolumn{2}{c|}{ Strengths } \\
& $\begin{array}{l}\bullet \text { Cap-and-trade funds } \\
\text { California }\end{array}$ & $\begin{array}{l}\bullet \text { Lack of sufficient funding to implement SCSs } \\
\bullet \text { Slow to change pace of transportation } \\
\bullet \text { Local land use authority }\end{array}$ \\
\hline Maryland & $\bullet$ n/a & $\begin{array}{l}\bullet \text { PlanMaryland weak and variable } \\
\bullet \text { Need funding for transit }\end{array}$ \\
\hline Oregon & $\bullet$ Statewide Land Use Program & $\bullet$ Need funding \\
\hline Washington & $\bullet$ Commute Trip Reduction & $\begin{array}{l}\bullet \text { Land use authority } \\
\text { Easy to change UGAs }\end{array}$ \\
& & $\begin{array}{l}\bullet \text { WSDOT } \\
\text { Need funding }\end{array}$ \\
\hline
\end{tabular}

\subsubsection{Strengths}

In some states, the strengths described related to programs that predated GHG legislation, while some states implemented new programs after passing GHG legislation. In Oregon and Washington, programs that predated GHG legislation but reduce GHG were seen as strengths. Statewide land use planning in Oregon and the Commute Trip Reduction program in Washington were strengths. In California, new programs were created to implement plans. Specifically, providing cap-and-trade funding for implementation of SB375 was generally viewed positively. In California, integrating Sustainable Communities Strategies with Regional Transportation Plans led to a shift in transportation spending. Within the transportation funding process, the approach acknowledges the state's interest in transportation funding and the MPO project selection and funding process has shifted away from road widening while some MPOs have begun tracking performance measures and using measures in project funding.

\subsubsection{Weaknesses}

By far, the most consistent and discussed weakness and obstacles in the overall approach was the lack of funding to implement plans. The lack of funding for transit and bicycle/pedestrian improvements were noted as key weaknesses in all four states. Even when plans and policies are in place, the lack of funding hinders implementation. In some cases, this lack of funding is driven by constitutional limitations on how certain types of can be spent (as in Oregon). In other instances, the lack of funding emerges from existing project selection structures and governing bodies which prefer roads. And in California, even though cap-and-trade funds exist, there were concerns about the way it was being allocated. Stakeholders thought that too much money was being spent on housing and not enough on transportation and infrastructure. A few stakeholders noted that the cap-and-trade funding should go to MPOs instead of SGC so that MPOs can implement plans.

Additional aspects were also seen as weaknesses in implementation, including the pace of transportation planning, land use authority and state plans. In California, stakeholders described 
the slow pace of changing transportation as a key weakness. In California and Washington, local land authority was seen as a key weakness in implementation. Even though Washington has urban growth areas, these were seen as malleable and easy to change. In Maryland, the lack of teeth in PlanMaryland was seen as a key weakness. In Oregon, stakeholders mentioned a general lack of enforcement authority. Related back to the policy framework, the OGWC was not given any authority, funding or budget. The STS Implementation Plan is difficult to implement because ODOT does not have overarching authority to tell other agencies what to do, although cooperation is necessary to reduce GHG. Additionally, Oregon's approach is not regulatory in nature, which makes it difficult to enforce. As one state agency put it, state agencies need a reason to say no. As one nonprofit stakeholder put it, NGOs need something they can sue over, and currently legislation does not provide this window.

\subsection{MONITORING}

This subsection summarizes what stakeholders reported as strengths and weaknesses related to tracking progress towards goals and targets, reporting, and revising goals or efforts in response. See Table 7.6.

Table 7.6: Monitoring Strengths and Weaknesses

\begin{tabular}{|l|l|ll|}
\multicolumn{1}{|c|}{ State } & \multicolumn{2}{c|}{ Strengths } & \multicolumn{1}{c|}{ Weaknesses } \\
\hline California & $\bullet$ n/a & $\bullet$ & Lack of feedback loop \\
\hline Maryland & $\bullet \mathrm{n} / \mathrm{a}$ & $\bullet$ & Lack of enforcement \\
\hline Oregon & $\bullet \mathrm{n} / \mathrm{a}$ & $\bullet$ & OGWC lacks funding or authority \\
\hline Washington & $\bullet$ n/a & $\bullet$ n/a \\
\hline
\end{tabular}

\subsubsection{Strengths}

Across all states, no strengths emerged in monitoring approaches.

\subsubsection{Weaknesses}

Three states described weaknesses in monitoring. In California, a few stakeholders noted that there is not a monitoring requirement in place to monitor SCS performance at the state level, though large emitters must report GHG emissions. Specifically, SCSs are not monitored for implementation. One stakeholder described the need for better performance measures overall.

In Oregon, OGWC was given very little staff and authority for monitoring progress. While OGWC creates biennial report cards, these are merely informational and do not force action. Additionally, there is no accountability for scenario planning in regions where the exercise is voluntary. In Washington, there were no accountability mechanisms for VMT benchmarks and GHG reduction requirements. 



\subsection{FINDINGS AND RECOMMENDATIONS}

The challenge is understood. "Human influence on the climate system is clear" (International Panel on Climate Change, 2014, 2). "Climate change is already affecting the American people in farreaching ways" (Melillo, Richmond and Yohe, 2014, 7). "Limiting climate change would require substantial and sustained reductions in greenhouse gas emissions" (International Panel on Climate Change, 2014, 8).

The needed response is also understood. Reducing GHG from transportation rests on the "threelegged stool" of improving vehicle efficiency, reducing the carbon content of fuels, and reducing vehicle miles traveled (VMT) (Ewing et al., 2007, 2). See Figure 1.1.

Whereas improving vehicle efficiency and reducing the carbon content of fuels likely requires national or at least multistate action to create markets sufficiently large to provide such vehicles and fuels (although California is large enough to create its own market), reducing VMT can and must be done at a more local level. The strategies for reducing VMT are understood:

- Transportation Options: Make transportation options that generate less GHG more attractive by investing in telecommuting, walking, bicycling, riding the bus, and carpooling.

- Pricing: Make transportation options that generate more GHG less attractive by attaching a price that more fully reflects the impacts, including impacts on the climate, for example, by adopting a carbon tax.

- Land Use Changes: Reduce the typical length and number of trips by promoting compact land use patterns that put more uses closer together and thus reduce the number of miles travelled, and that make walking, bicycling, riding the bus, and carpooling more attractive.

In general, we applaud the leadership and efforts of our case study states-California, Maryland, Oregon and Washington-especially in an era when there is little action at the national level.

But in general, our research finds a significant gap between goals and results, between "the talk" and "the walk." Efforts have been stronger on plans but weaker on actions. For example, Oregon in 1989 adopted Senate Bill 576 establishing Oregon's first GHG reduction goals, and in 1990 developed recommendations to reduce VMT through a combination of transportation and land use efforts (Oregon Task Force on Global Warming, 1990). In the last quarter century, Oregon has continued to redevelop variations of the same policies. Oregon's experience in climate change planning isn't unique (although its land use planning program gives it a leg up on other states, for example California).

In brief, our research finds shortcomings in "connect the dots" from goals to plans to actions to results, as conveyed in Figure 3.1. In many cases, this stems from a dissonance between 
aspirational goals established by legislatures, implementation by a variety of state, regional and local agencies, and monitoring by state environmental agencies.

This section summarizes our key findings and recommendations. These are organized into the themes described in Section 3.4 above: leadership, policy framework, planning, institutional relationships, implementation, monitoring, and regional and local support. For each recommendation, we suggest who could adopt the recommendation and, if applicable, a model jurisdiction from our case studies.

\subsection{LEADERSHIP}

This subsection summarizes our key findings and recommendations related to motivation, vision and (executive) leadership. See Table 8.1.

Table 8.1: Leadership Findings and Recommendations

\begin{tabular}{|c|c|c|c|}
\hline Finding & Recommendation & Who? & Model \\
\hline $\begin{array}{l}1.1 \text { States leading despite } \\
\text { absence of comprehensive } \\
\text { national effort }\end{array}$ & $\begin{array}{l}\text { a) Other states should follow the lead } \\
\text { of those already addressing climate } \\
\text { change } \\
\text { b) Need comprehensive national effort }\end{array}$ & $\begin{array}{l}\text { Executive; } \\
\text { Legislature; } \\
\text { President; } \\
\text { Congress }\end{array}$ & California \\
\hline $\begin{array}{l}1.2 \text { Political polarization makes } \\
\text { progress difficult }\end{array}$ & $\begin{array}{l}\text { Insulate implementation from the } \\
\text { political process by relying on a } \\
\text { Climate Change Commission rather } \\
\text { than the legislature }\end{array}$ & Legislature & Maryland \\
\hline $\begin{array}{l}1.3 \text { States learn from other states } \\
\text { (e.g., WCGGWI, WCI, PCC) }\end{array}$ & $\begin{array}{l}\text { Multistate collaboration can be helpful } \\
\text { for encouraging action }\end{array}$ & $\begin{array}{l}\text { Executive; } \\
\text { State agencies; } \\
\text { Regional } \\
\text { collaborations }\end{array}$ & $\begin{array}{l}\text { Oregon; } \\
\text { Washington }\end{array}$ \\
\hline $\begin{array}{l}1.4 \text { "Tragedy of the Commons" } \\
\text { nature of climate change } \\
\text { discourages state, regional } \\
\text { and local governments from } \\
\text { acting }\end{array}$ & $\begin{array}{l}\text { Focus on co-benefits of reducing } \\
\text { GHG, in particular, from } \\
\text { transportation sector }\end{array}$ & $\begin{array}{l}\text { Executive; } \\
\text { Legislature; } \\
\text { State agencies; } \\
\text { MPOs }\end{array}$ & Portland MPO \\
\hline $\begin{array}{l}\text { 1.5 Changes in political } \\
\text { leadership undermines } \\
\text { consistent implementation }\end{array}$ & $\begin{array}{l}\text { Require interim reports and sunset } \\
\text { clauses so legislature must stay } \\
\text { engaged }\end{array}$ & Legislature & Maryland \\
\hline $\begin{array}{l}\text { 1.6 Changes in state agency } \\
\text { leadership undermines } \\
\text { consistent implementation }\end{array}$ & $\begin{array}{l}\text { Establish a commission with broad } \\
\text { authority drawn from leaders in the } \\
\text { public and private sectors that uses } \\
\text { staggered appointment terms to } \\
\text { insulate from political changes }\end{array}$ & Legislature & Maryland \\
\hline $\begin{array}{l}1.7 \text { Emphasis often varies across } \\
\text { administrations; each } \\
\text { attempts to make mark with } \\
\text { new policies } \\
\end{array}$ & $\begin{array}{l}\text { Need consistent leadership- } \\
\text { executive, legislative giving advice to } \\
\text { agencies }\end{array}$ & $\begin{array}{l}\text { Executive; } \\
\text { Legislature }\end{array}$ & $\mathrm{n} / \mathrm{a}$ \\
\hline $\begin{array}{l}\text { 1.8 Advocacy groups play } \\
\text { important role in pushing } \\
\text { policy agenda }\end{array}$ & $\begin{array}{l}\text { Advocacy groups push for incremental } \\
\text { policy change, calling for modest steps } \\
\text { with clear accountability to keep issue } \\
\text { present }\end{array}$ & $\begin{array}{l}\text { Advocacy } \\
\text { groups }\end{array}$ & $\begin{array}{l}1000 \text { Friends of } \\
\text { Oregon }\end{array}$ \\
\hline
\end{tabular}

Any significant action requires leadership to make it happen. 
The four case study states-California, Maryland, Oregon and Washington-are all leading the way on climate change, despite the absence of a comprehensive national effort and the challenges of some states trying to act unilaterally. We commend all four states, call on other states to follow their lead, and see the need for a comprehensive national (and international) response to the threat of climate change.

Political polarization makes progress difficult. For example, in Washington, despite strong leadership by a series of governors and an effort to frame efforts to combat climate change as an economic development opportunity, the executive and a controlling majority of the legislature have been at odds over taking efforts to advance adopted goals.

On the West Coast, states participated in the West Coast Governors’ Global Warming Initiative (WCGGWI) and called on states to adopt comprehensive GHG reduction goals. Oregon and Washington stakeholders reported that WCGGWI was important in spurring their initial steps. Subsequently, the Western Climate Initiative developed a recommended cap-and-trade approach, and the Pacific Coast Collaborative (PCC) is working towards a low-carbon economy. We recommend states in other regions across the country collaborate to exchange information and spur joint or separate efforts.

A common theme heard for entire states, for the transportation sector and the light-duty vehicles subsector, and for particular regions was that there is little point to acting alone. For example, Oregon, the smallest of the four case study states in population, could act or not and it would have little measurable impact on GHG and climate change globally. The same theme was voiced even stronger for smaller MPOs. Of course, such thinking leads to a "Tragedy of the Commons." Absent a comprehensive national (and international) response to the threat of climate change, it is understandable that smaller jurisdictions might be reluctant to act without confidence that others will join the effort. But California is large enough that its efforts alone are significant, and in partnership with other states even more so. The Portland MPO found that local co-benefits (lower energy costs, more money in the local economy, improved public health, etc.) were sufficient and actually more compelling reasons to act than simply combating a global problem.

In all states examined, shifts in political or state agency leadership have undermined implementation. Each governor and legislature comes in with new policies and priorities, and agencies must shift focus as a result. There are a couple of different ways to ease this transition. One method relies on sunset clauses and interim reports that require legislative action. Another method involves relying on a commission with broad representation and staggered terms to take appointment power out of the sole hands of a governor or legislature. This approach was particularly effective in Maryland.

Across all states, there is a need for consistent leadership in which the legislature and executive give advice to agencies and remain engaged in the process.

Governors and other government officials can't be expected to lead alone. Advocacy groups play a critical role in pushing a policy agenda and providing political cover for government actions with mixed support. For example, environmental advocacy groups pushed to include provisions related to reducing GHG in Oregon's 2009 transportation funding package (HB2001). To be more 
effective, advocacy groups should focus on incremental change, asking for small, doable steps, and insisting on accountability (biennial reports, etc.) to keep the issue present.

\subsection{POLICY FRAMEWORK}

This subsection summarizes our key findings and recommendations related to the policy framework, or how key legislation is structured. See Table 8.2.

Table 8.2: Policy Framework Findings and Recommendations

\begin{tabular}{|l|l|l|l|}
\hline \multicolumn{2}{|c|}{ Finding } & \multicolumn{2}{|c|}{ Recommendation } \\
\hline 2.1 Failure to "connect the dots" & $\begin{array}{l}\text { Consider a SMART approach to establishing } \\
\text { goals, that are Specific, Measurable, } \\
\text { Actionable, Realistic and Time-bound }\end{array}$ & Legislature & $\begin{array}{l}\text { Maryland; } \\
\text { California }\end{array}$ \\
\hline $\begin{array}{l}\text { MPOs can be effective } \\
\text { instrument }\end{array}$ & $\begin{array}{l}\text { If MPOs are strong, they can be an effective } \\
\text { instrument for reducing GHG }\end{array}$ & Legislature & $\begin{array}{l}\text { California } \\
\text { (some MPOs) }\end{array}$ \\
\hline
\end{tabular}

As noted above, research found to varying degrees a failure to "connect the dots" from goals to plans to actions to results. For example, California is requiring MPOs to take action but isn't necessarily providing adequate funding; Oregon is requiring some MPOs to adopt plans but has few provisions for implementing these plans; and Washington adopted statewide GHG "limits" and VMT "benchmarks" but assigns no particular agency responsibility for achieving these, in whole or part.

Figure 8.1 shows the process of management by objectives to establish a clear feedback loop between goals, implementation and evaluation. Rather than the linear process described in Figure 3.1, this approach relies on creating a feedback loop from evaluation into goal-setting.

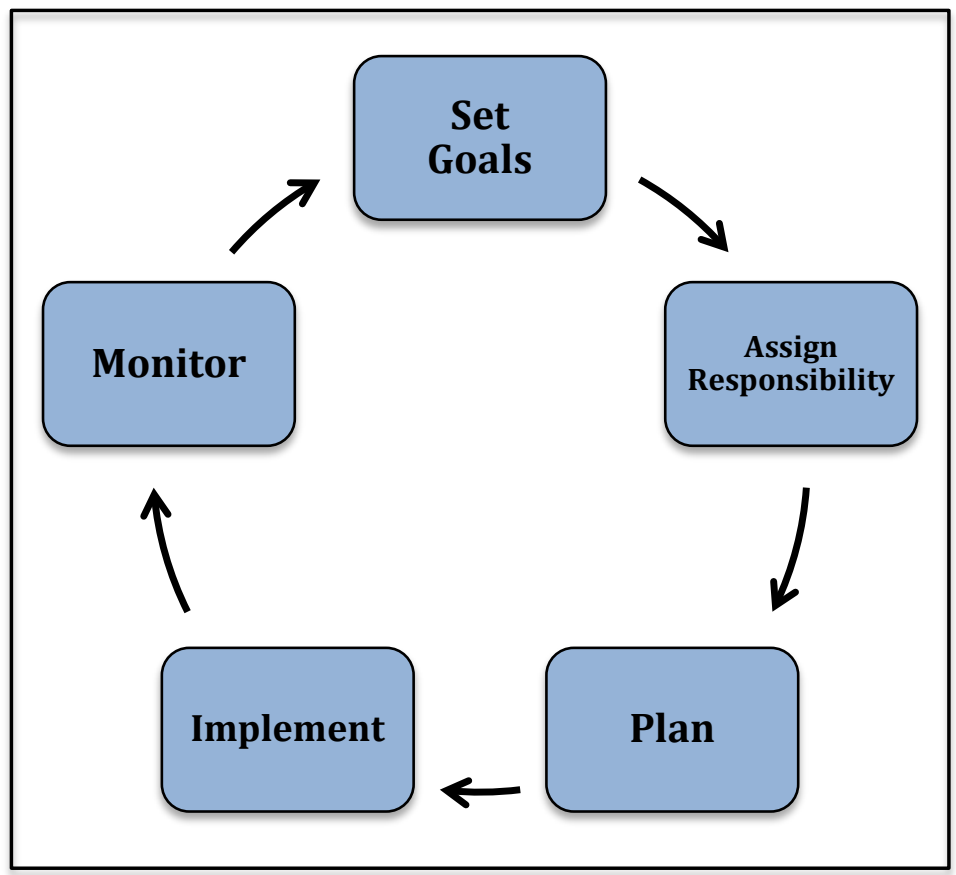

Figure 8.1: The Five-Step Management by Objectives Process 
Under this framework, goals are expected to be SMART: Specific, Measurable, Actionable, Realistic and Time-bound. The case studies include many examples of efforts that aren't SMART.

In particular, goals should be realistic in the sense that there exist feasible paths for achieving the goals - at least with sufficient financial resources, political will, and other necessary resources. Setting goals with no realistic hope of achieving them leads to the goals not being taken seriously. On the other hand, given the magnitude of the task, goals should not be "watered down" in the face of political challenges to the point of not facing up to the climate change challenges. Goals need to be as aggressive as feasible while still be realistically achievable.

For example, while most approaches include "time-bound" goals, many goals were established by legislatures without consideration of whether ambitious goals are achievable under current policies or would require new policies and funding. As we enter the second wave of state climate planning in which states begin to update targets and plans, we recommend shifting to a SMART approach.

The policy framework should:

- Set SMART goals.

- Assign responsibility for achieving each goal (or performance measure) to a specific agency, and engage that agency in goal setting.

- Ensure that each responsible agency has sufficient authority and resources to be successful.

- Evaluate progress regularly.

- Revisit the goals and efforts in light of results.

In drafting legislation, California and Oregon have shown that the MPOs can be an effective instrument for planning to reduce GHG. However, this approach is more effective when MPOs have significant control over project selection.

\subsection{GOALS}

This subsection summarizes our key findings and recommendations related to overall GHG reduction goals and transportation-specific targets. See Table 8.3.

Table 8.3: Goals Findings and Recommendations

\begin{tabular}{|c|c|c|c|}
\hline Finding & Recommendation & Who? & Model \\
\hline $\begin{array}{l}\text { 3.1 Goals often set in a } \\
\text { vacuum by legislature } \\
\text { without understanding } \\
\text { of implications }\end{array}$ & $\begin{array}{l}\text { a) Set SMART goals } \\
\text { b) Set goals with understanding of impact of existing } \\
\text { policies, new policies and new funding sources } \\
\text { c) Use a hybrid approach of "how far can you get?" } \\
\text { and "what would it take?” }\end{array}$ & $\begin{array}{l}\text { Legislature; } \\
\text { State agencies }\end{array}$ & $\begin{array}{l}\text { Baltimore } \\
\text { MPO }\end{array}$ \\
\hline $\begin{array}{l}\text { 3.2 Often difficult to link } \\
\text { results back to actions }\end{array}$ & $\begin{array}{l}\text { Develop a set of performance measures more closely } \\
\text { tied to actions }\end{array}$ & $\begin{array}{l}\text { State agencies; } \\
\text { MPOs }\end{array}$ & Oregon \\
\hline $\begin{array}{l}\text { 3.3 MAP-21 calls for } \\
\text { performance measures }\end{array}$ & $\begin{array}{l}\text { Regardless of federal efforts, develop state and } \\
\text { regional performance measures related to GHG } \\
\text { reduction }\end{array}$ & $\begin{array}{l}\text { State agencies; } \\
\text { MPOs }\end{array}$ & $\mathrm{n} / \mathrm{a}$ \\
\hline
\end{tabular}


In designing policy, we found that goals in all states were set in a vacuum without considering whether current policies and funding mechanisms would be adequate to reach these goals. Because implementation has lagged in several states, we recommend taking a hybrid approach of "how far can you get" with available policy tools alongside "what would it take" to reach goals. As noted above, goals should be SMART: Specific, Measurable, Actionable, Realistic and Time-bound. This will provide states with more robust information about the feasibility of reaching goals under existing conditions. The Baltimore Metropolitan Council utilized a "how far can we get" study (Baltimore Metropolitan Council, 2015). That said, a hybrid approach would be to maintain both aspirational "what do you need to do" and realistic "how far can you get” goals side by side.

Often it is difficult to link results back to actions. For example, in assessing progress in meeting its GHG reduction goals, Washington reported some success-but attributed this primarily to the decline in the electricity-intensive aluminum industry and a decline in driving as a result of the Great Recession. Rather than-or in addition to-setting GHG and VMT reduction goals, adopt performance measures more closely tied to what a particular agency has the power to do. For example, Oregon's Transportation Planning Rule (Oregon Administrative Rule 660-012) originally in 1991 called for MPOs to reduce VMT significantly, but today calls for alternative performance measures likely to lead to reduced VMT but more closely related to what MPOs can accomplish.

MAP-21 calls for transportation performance measures (U.S. Federal Highway Administration, 2016a). FHWA recently published performance management final rules (U.S. Federal Highway Administration, 2016b). State agencies and MPOs have an opportunity to adopt performance measurements related to GHG within the MAP-21 framework.

\subsection{PLANNING}

This subsection summarizes our key findings and recommendations related to aspects of state, regional and local planning processes. See Table 8.4.

Table 8.4: Planning Findings and Recommendations

\begin{tabular}{|c|c|c|c|}
\hline Finding & Recommendation & Who? & Model \\
\hline $\begin{array}{l}\text { 4.1 Integrate RTPs with } \\
\text { plans to reduce GHG }\end{array}$ & $\begin{array}{l}\text { Require MPOs to show how RTPs reduce GHG } \\
\text { and give MPOs oversight over project selection }\end{array}$ & $\begin{array}{l}\text { Federal agencies: } \\
\text { State agencies }\end{array}$ & California \\
\hline 4.2 MPOs vary in capacity & $\begin{array}{l}\text { Provide technical and financial support for } \\
\text { planning }\end{array}$ & State agencies & $\begin{array}{l}\text { Oregon; } \\
\text { California }\end{array}$ \\
\hline
\end{tabular}

One way to use MPOs to reduce GHG is to integrate regional transportation plans (RTPs) with plans to reduce GHG. Requiring MPOs to integrate RTPs with plans to reduce GHG can be an effective tool, if MPOs have authority over project selection. Relying on RTPs is effective in California because MPOs have a high level of oversight over project selection. This is a shift that could emerge from the federal level as a requirement for receiving federal funding, but could be implemented at the state level as well. Further, states should require performance measures related to GHG and other metrics in the transportation project selection process.

Because MPOs vary in capacity, it is important to provide technical support and funding for planning, especially in smaller MPOs. This is particularly true in California where MPOs range 
drastically in size, but was true in Oregon as well where MPOs have not chosen to voluntarily engage in scenario planning because of the lack of funding.

\subsection{INSTITUTIONAL RELATIONSHIPS}

This subsection summarizes our key findings and recommendations related to relationships between state, regional and local agencies, focusing on horizontal relationships among agencies at the same level and vertical relationships between levels. See Table 8.5.

Table 8.5: Institutional Relationships Findings and Recommendations Finding Recommendation

Model

\begin{tabular}{|c|c|c|c|}
\hline Finding & Recommendation & Who? & Model \\
\hline $\begin{array}{l}5.1 \text { Transportation agencies are not designed } \\
\text { to deal with GHG }\end{array}$ & $\begin{array}{l}\text { Use SSTI to assess transportation } \\
\text { agency }\end{array}$ & State agencies & California \\
\hline $\begin{array}{l}\text { 5.2 Transportation agencies often make all } \\
\text { decisions related to transportation } \\
\text { placement, even though decisions impact } \\
\text { land use and GHG }\end{array}$ & $\begin{array}{l}\text { Incorporate other state agencies } \\
\text { into decision-making }\end{array}$ & State agencies & $\mathrm{n} / \mathrm{a}$ \\
\hline 5.3 MPOs are not strong in all states & $\begin{array}{l}\text { Give MPOs oversight over project } \\
\text { selection }\end{array}$ & Legislature & California \\
\hline 5.4 County governments are strong & $\begin{array}{l}\text { Provide locals incentives to change } \\
\text { plans (tie funding to plans or UGB } \\
\text { expansion) }\end{array}$ & State agencies & $\mathrm{n} / \mathrm{a}$ \\
\hline
\end{tabular}

Across all states, transportation agencies struggle to implement legislation to reduce GHG. The transportation agency is charged with moving goods and people and struggles to shift orientation to consider GHG. Other agencies often find it frustrating to work with DOTs to reduce GHG. The problem is intensified because transportation agencies have control over funding and project selection. California underwent an assessment from State Smart Transportation Initiative (SSTI) that led to a shift in orientation to begin to change the culture of Caltrans. In other states, incorporating other agencies into decision-making processes by encouraging horizontal coordination can be effective.

While MPOs make sense in California, MPOs across the country are not as strong as California. By giving MPOs oversight over project selection and requiring MPOs to reach GHG targets, states might begin to make progress toward reducing GHG from transportation. In California, the relationship and communication between MPOs and state agencies improved after SB375.

In other states, like Maryland, strong county governments have undermined implementation. One approach to overcoming this obstacle is by providing locals with incentives to change plans.

\subsection{IMPLEMENTATION}

This subsection summarizes our key findings and recommendations related to aspects of implementing plans, strategies and policies. See Table 8.6. 
Table 8.6: Implementation Findings and Recommendations

\begin{tabular}{|c|c|c|c|}
\hline Finding & Recommendation & Who? & Model \\
\hline $\begin{array}{l}\text { 6.1 State authority over land use } \\
\text { provides an opportunity to } \\
\text { encourage compact } \\
\text { development }\end{array}$ & $\begin{array}{l}\text { Make provision of transportation funding } \\
\text { contingent on approval of land use plans } \\
\text { focused on compact development. In states with } \\
\text { strong land use planning, make boundary } \\
\text { expansion contingent on scenario planning }\end{array}$ & State agencies & $\mathrm{n} / \mathrm{a}$ \\
\hline $\begin{array}{l}6.2 \text { Lacking flexible funding } \\
\text { sources to implement plans }\end{array}$ & Remove constitutional limitations on gas tax & Legislature & $\mathrm{n} / \mathrm{a}$ \\
\hline $\begin{array}{l}\text { 6.3 Cap-and-trade funding } \\
\text { provides flexible funding } \\
\text { source to implement plans }\end{array}$ & $\begin{array}{l}\text { Encourage competitive cap-and-trade programs } \\
\text { or carbon taxes to implement plans and projects }\end{array}$ & Legislature & California \\
\hline $\begin{array}{l}6.4 \text { Regulations prevent } \\
\text { compact development }\end{array}$ & $\begin{array}{l}\text { Relax regulations to incentivize compact } \\
\text { development, bicycle/pedestrian infrastructure } \\
\text { and transit infrastructure }\end{array}$ & Legislature & California \\
\hline
\end{tabular}

State authority over land use planning offers an opportunity to encourage compact development to reduce VMT, but MPOs can use incentives (or hold back funding for transportation) to persuade locals to participate. States must work within the existing land use policy framework, as strengthening the state role is unlikely in many states. In Oregon UGBs were seen as very strong, and in California many stakeholders wished for strong land use. In states without strong state control over land use, states could make the provision of transportation funding contingent on approval of land use plans focused on compact development to reduce GHG. This could be an important lever for local implementation, particularly in states like California that lack a strong state land use program. In states with strong land use planning like Oregon, make land use plan revision or urban growth area/boundary expansion contingent on engaging in scenario planning to reduce GHG.

States and MPOs lack flexible funding sources to implement plans. A constitutional restriction on gas tax money limits the amount of funding available for transit and bicycle or pedestrian projects. The Portland MPO found that existing plans would reach GHG targets, but the region lacked funding to be able to implement plans. We recommend removing constitutional and statutory limitations on the use of transportation revenue sources.

Cap-and-trade programs can provide a flexible funding source to implement plans. California provides an example of using competitive cap-and-trade funding to implement plans and projects.

When funding is not available, states can relax regulations to incentivize compact development and bicycle, pedestrian and transit infrastructure. California provides an example of relaxing CEQA to encourage infill.

\subsection{MONITORING}

This subsection summarizes our key findings and recommendations related to tracking progress towards goals and targets, reporting, and revising goals or efforts in response. See Table 8.7. 
Table 8.7: Monitoring Findings and Recommendations

\begin{tabular}{|c|c|c|c|}
\hline Finding & Recommendation & Who? & Model \\
\hline $\begin{array}{l}\text { 7.1 States lack institutional structure } \\
\text { to provide oversight of } \\
\text { implementation of plans }\end{array}$ & $\begin{array}{l}\text { Provide monitoring and enforcement to } \\
\text { state agency with staff, funding, } \\
\text { authority }\end{array}$ & Legislature & $\mathrm{n} / \mathrm{a}$ \\
\hline 7.2 Need to hold MPOs accountable & Track VMT and GHG at MPO level & State agencies & $\begin{array}{l}\text { California; } \\
\text { Oregon }\end{array}$ \\
\hline $\begin{array}{l}\text { 7.3 Plans are not monitored for } \\
\text { implementation }\end{array}$ & $\begin{array}{l}\text { Rely on public sector or civic sector to } \\
\text { monitor plans. }\end{array}$ & $\begin{array}{l}\text { State agencies; } \\
\text { Civic sector }\end{array}$ & California \\
\hline
\end{tabular}

Monitoring was weak in all states. No states have developed a mechanism that allows for a feedback loop between goals, actions and results. We recommend providing monitoring and enforcement authority to a state agency with staff and authority to provide oversight and monitoring of implementation of plans. Oregon created a Global Warming Commission to oversee GHG reduction efforts, but failed to provide adequate legislative authority or staff.

It is essential to hold MPOs accountable for targets (that are SMART). For example, in Washington a court ruled that the statewide targets to reduce VMT did impose a requirement on MPOs to reduce VMT (Washington State Court of Appeals, 2013). California's and Oregon's practice of disaggregating statewide goals into regional targets is a good approach. But too rigid an approach of MPOs including in-boundary but excluding out-boundary VMT, as is done in Oregon, creates perverse incentives.

Although MPOs are required to show that plans will meet long-range targets in California and Portland, the states do not monitor plans for implementation. MPOs have to say how they plan to reduce GHG, but no one tracks whether they are actually implementing the policies laid out. Tracking implementation would provide a tighter feedback loop between goals, efforts and results. ClimatePlan in California offers an example of the civic sector undertaking plan monitoring outside of state requirements. States should fund the civic sector to complete these evaluations to provide an outside perspective on implementation.

\subsection{REGIONAL AND LOCAL SUPPORT}

This subsection summarizes our key findings and recommendations related to developing support for regional and local efforts. See Table 8.8.

Table 8.8: Regional and Local Support Findings and Recommendations

\begin{tabular}{|ll|l|l|l|}
\hline \multicolumn{2}{|c|}{ Finding } & \multicolumn{1}{c|}{ Who? } & Model \\
\hline $\begin{array}{l}\text { 8.1 } \\
\text { to sustizen buy-in important }\end{array}$ & $\begin{array}{l}\text { Build public support by emphasizing co- } \\
\text { benefits of reducing GHG }\end{array}$ & Public agencies & All \\
\hline $\begin{array}{l}\text { 8.2 } \\
\text { Difficult to get buy-in as } \\
\text { state agencies }\end{array}$ & Rely on civic sector to build coalitions & Civic sector & $\begin{array}{l}\text { Maryland; } \\
\text { California }\end{array}$ \\
\hline
\end{tabular}

In sustaining support for greenhouse gas reduction efforts, it is important to engage the public throughout the process and communicate with the public about the plans. Several stakeholders noted that talking about GHG levels or even climate change often falls flat with the public. Instead, with the help of civic groups, government agencies should build broad public support for actions that reduce GHG from transportation by emphasizing concurrent benefits such as sustainable economic development, public health, reduced congestion, and greater accessibility. 



\subsection{CONCLUSIONS}

\subsection{KEY FINDINGS}

The states examined in this report-California, Maryland, Oregon and Washington-are progressive in adopting statutory GHG reduction goals and legislation focused on the transportation sector. In each of these states, there is modest public support and political will for climate change policy. While national climate legislation is lacking, these states are exemplars in adopting state-level legislation to reduce GHG. In these states, the initial legislation setting goals and requiring plans to determine how goals will be met is a starting place for making progress towards reducing GHG from transportation.

The states examined in this report-California, Maryland, Oregon and Washington-are progressive in adopting statutory GHG reduction goals and legislation focused on the transportation sector. While national climate legislation is lacking, these states are exemplars in adopting state-level legislation to reduce GHG. In these states, the initial legislation setting goals and requiring plans to determine how goals will be met is a starting place for making progress towards reducing GHG from transportation. Key conclusions are summarized below:

- Sustained leadership and momentum on common legislation and policies is key to successful implementation. In adopting policies, environmental groups have been important players in pushing legislation and sustaining emphasis on implementation.

- States need to "connect the dots” from goals to plans to actions to results. States lack clear monitoring authority. There is a need to link goals more directly to feasible actions and have a tighter feedback loop between goals, plans, actions and results.

- In crafting a policy designed to reduce GHG from transportation, it made sense to rely on MPOs in California and Oregon, and to allow for flexibility in how to reach targets.

- In crafting state policy, there is a clear need to align authority, responsibility and resources with those in a position to take actions. Creating new commissions that lack staff and authority has not been effective.

This research finds that sustained leadership and momentum on common legislation and policies is key to successful implementation. In states (like California) where the governor or executive took ownership over legislation, implementation has been strong and consistent. In states where the executive and legislature did not take ownership over the programs and the players are changing, or where competing leadership has been pulling in different directions (like Washington), implementation has lagged since legislation went into effect. In general, there is a need to better "connect the dots" from goals to plans to actions to results. A lack of sustained and sufficient political leadership has led to efforts too limited to result in desired goals. Leadership 
and mandates from the federal level, though unlikely in the current political climate, could help overcome leadership transitions at the state level.

However, several stakeholders reported that communicating with the public about GHG reduction efforts was more successful when focused on "co-benefits." Other reasons for reducing VMT (lower energy costs, more money in the local economy, improved public health, etc.) can be sufficient for taking action now and make it is easier to get public buy-in while broadening the focus beyond just climate change.

In crafting state policy, there is a need to link goals more directly to feasible actions and have a tighter feedback loop between goals, plans, actions and results. Often, it is easy to measure GHG levels but difficult to evaluate how various policies affected GHG levels to attribute success or failure to specific policies.

In crafting state policy, there is a clear need to align authority, responsibility and resources with those in a position to take actions. Creating new commissions that lack staff and authority has not been effective.

Further, because housing decisions are long term, it is difficult to reduce GHG from VMT in the short run. Land use change is incremental and slow; expanding transit to areas not currently served is expensive and can take decades; and while increasing transportation pricing can reduce VMT, this approach can pose equity impacts beyond political challenges and perceived economic impacts. Additionally, reducing VMT requires that public actions influence private choices.

Though scenario planning models and plans are improving, these will not be successful without adequate funding and a reorientation of priorities. In an era when transportation funding is limited and several revenue sources are constitutionally or statutorily constrained, finding adequate resources for plans designed to reduce GHG is a major obstacle. Though these states possess general public support for climate change policies, it can be difficult to gain enough institutional support to reverse ingrained policies and practices that continue to encourage driving.

In crafting a policy designed to reduce GHG, it was logical to rely on MPOs and to allow for flexibility in how to reach targets. In monitoring progress, states currently lack strong oversight over implementation. While state agencies are involved in target setting and plan approval, there is little oversight of the plans once adopted. Providing authority, budget and staff to an agency charged with oversight could improve the monitoring of plans.

In adopting policies, environmental groups have been important players in pushing legislation and sustaining emphasis on implementation. In California and Washington, environmental groups have filed lawsuits against MPOs related to their responsibilities under state law.

Overall, in the absence of a national framework for combating climate change, states have stepped up to adopt innovative policy that goes beyond federal and international policy. While we note the need for a national (or international) framework for combating climate change, efforts to reduce VMT can and must occur at the metropolitan and state levels and need not wait for national leadership. 
While innovative states have showed a pathway for other states in establishing policy frameworks that may mitigate transportation emissions, many of the state level frameworks examined here were put into place at the height of the recession. Thus, though preliminary emissions measurements show a reduction in VMT and GHG, it is unclear whether these trends will be sustained or whether reductions are attributed to the Great Recession or policy change. At this point, it is highly uncertain that states will be able to meet long range targets. After the low-hanging fruit is picked, more radical policy innovation will be needed in the future.

\subsection{OPPORTUNITY FOR FUTURE WORK}

This project has revealed interesting findings about the integration of climate, transportation and land use planning, and offered an assessment of innovative states which have adopted legislation to reduce GHG. Future work could expand the topic to additional states that are less well-known in climate legislation. Additionally, it would be valuable to conduct case studies of innovative regions and local governments.

Further work could illuminate how to build a feedback loop relying on a SMART framework to better track the relationship between goals, efforts and results. Current work by Zako, Lewis, Biddle and Isbell begins to make this connection between livability goals and transportation spending.

With the issuance of proposed rulemaking in April of 2016, the timing is ripe to consider the role of the federal government in reducing GHG from transportation. One approach might entail pilot projects funded by FHWA. 



\subsection{REFERENCES}

Baer, William C. 1997. "General plan evaluation criteria: An approach to making better plans.” Journal of the American Planning Association 63: 329-45.

Barbour, Elisa, and Elizabeth A. Deakin. 2012. "Smart Growth Planning for Climate Protection: Evaluating California's Senate Bill 375.” Journal of the American Planning Association 78(1): 70-86.

Baltimore Metropolitan Council. 2015. “How Far Can We Get?” Accessed May 28, 2016. http://baltometro.org//phocadownload/Publications/Environment/2015_HowFarCanWeGetR eport.pdf.

Boswell, Michael, Adrienne Greve, and Tammy Seale. 2010. An Assessment of the Link Between Greenhouse Gas Emissions Inventories and Climate Action Plans. Journal of the American Planning Association 76(4): 451-462.

—. 2012. Local Climate Action Planning. Washington, DC: Island Press.

Burbank, Cynthia. 2009. Strategies for Reducing the Impacts of Surface Transportation on Global Climate Change: Synthesis of Policy Research and State and Local Mitigation Strategies. NCHRP Project 20-24(59). Requested by American Association of State Highway and Transportation Officials.

Burby, Raymond J., and Peter May. 1997. Making Governments Plan. Baltimore: Johns Hopkins University Press.

Bulkeley, Harriet. 2010. Cities and the Governing of Climate Change. The Annual Review of Environmental Resources 35: 229-253.

Bulkeley, Harriet, and Michele Betsill. 2003. Cities and Climate Change: Urban sustainability and global environmental governance. New York, NY: Routledge.

- 2013. Revising the urban politics of climate change. Environmental Politics 22(1): 136154.

California Air Resources Board. 2014. "First Update to the Climate Change Scoping Plan.” Accessed May 28, 2016. http://www.arb.ca.gov/cc/scopingplan/2013_update/first_update_climate_change_scoping_pl an.pdf. 
California Department of Transportation. 2015. “Transportation Funding in California.” Accessed May 28, 2016.

http://www.dot.ca.gov/hq/tpp/offices/eab/fundchrt_files/Transportation_Funding_in_CA_Ne w.pdf.

. 2016. “California Transportation Plan 2040: Final Review Draft.” Accessed May 28, 2016. http://www.dot.ca.gov/hq/tpp/californiatransportationplan2040/final-draftctp2040/docs/ctp2040-final-draft.pdf.

California Department of Finance. 2016. “California Governor’s Budget: Environmental Protection. Accessed May 30, 2016. http://www.ebudget.ca.gov/201516/Enacted/StateAgencyBudgets/3890/agency.html.

California Government Code §65302. Accessed May 30, 2016. http://www.leginfo.ca.gov/cgibin/displaycode?section=gov\&group $=65001-66000 \&$ file $=65300-65303.4$.

California Public Resources Code §21099. Accessed May 30, 2016. http://www.leginfo.ca.gov/cgi-bin/displaycode?section=prc\&group=21001$\underline{22000 \& \text { file }=21099}$.

Cambridge Systematics. 2009. Moving Cooler: An Analysis of Transportation Strategies for Reducing Greenhouse Gas Emissions. Washington, D.C: Urban Land Institute.

Campoli, Gina. 2012. "Facing Up to Climate Change: Planning and Implementation at the Vermont Agency of Transportation.” TR News 281 (July-August): 13-14.

Carruthers, John. I. 2002. "Evaluating the effectiveness of regulatory growth management programs: An analytic framework." Journal of Planning Education and Research 21: 391405.

Center for Climate and Energy Solutions. 2016. “Climate Action Plans.” Accessed May 28, 2016. http://www.c2es.org/us-states-regions/policy-maps/climate-action-plans/.

Cohen, James. 2002. “Maryland’s “Smart Growth”: Using Incentives to Combat Sprawl.” In Urban Sprawl: Causes, Consequences, and Policy Responses, edited by Gregory D. Squires. Urban Institute: Washington, D.C.

Clucas, Richard. 2009. “Oregon” In Political Encyclopedia of U.S. States and Regions, edited by Donald P. Haider-Markel. Washington, DC: CQ Press.

Crane, Randal. 2000. The influence of urban form on travel: an interpretative review. Journal of Planning Literature 15(1): 3-23.

Curry, James M. 2009. “Maryland.” In Political Encyclopedia of U.S. States and Regions, edited by Donald P. Haider-Markel. Washington, DC: CQ Press.

Economist. 2011. “The withering branch.” Economist, April 20. Accessed May 28, 2016. http://www.economist.com/node/18563620. 
Ewing, Reid, Keith Bartholomew, Steve Winkelman, Jerry Walters, and Don Chen. 2007. Growing Cooler: The Evidence on Urban Development and Climate Change. Washington, D.C.: Urban Land Institute.

Ewing, Reid, and Robert Cervero. 2001. “Travel and the built environment” Transportation Research Record 1780: 87-114.

Fulton, William. 2015. "Will Climate Change Save Growth Management in California?” In Planning for States and Nation-States in the U.S. and Europe, edited by Gerrit-Jan Knaap, Zorica Nedovic-Budic, and Armando Carbonell. Cambridge, MA: Lincoln Institute of Land Policy.

Gale, Dennis E. 1992. "Eight state-sponsored growth management programs: A comparative analysis.” Journal of the American Planning Association 58: 425.

Hodson, T. 2009a. “California.” In Political Encyclopedia of U.S. States and Regions, edited by Donald P. Haider-Markel. Washington, DC: CQ Press.

—. 2009b. "Washington.” In Political Encyclopedia of U.S. States and Regions, edited by Donald P. Haider-Markel. Washington, DC: CQ Press.

Howell-Moroney, Michael I. 2007. "Studying the effects of the intensity of US state growth management approaches on land development outcomes.” Urban Studies 44: 2163-78.

ICF International. 2011. "Synthesis of Climate Change and Transportation Research Efforts at State DOTs, State Universities, and Federal Level.” Accessed May 28, 2016. http://climatechange.transportation.org/pdf/CCandTransSynthesis_NCHRP_7 15 11.pdf.

International Panel on Climate Change. 2014. Climate Change 2014: Synthesis Report. Contribution of Working Groups I, II and III to the Fifth Assessment Report of the Intergovernmental Panel on Climate Change. Accessed May 31, 2016. http://ar5syr.ipcc.ch/.

Johnson, Gregory C., Niles Annelin, and Kristin Schuster. 2012. "Climate Change Adaptation in Michigan: Preparations, Strategies, and Examples.” TR News 281 (July-August): 5-9.

Knaap, Gerrit-Jan. 2015. “Using Incentives to Combat Sprawl: Maryland’s Evolving Approach to Smart Growth.” In Planning for States and Nation-States in the U.S. and Europe, edited by Gerrit-Jan Knaap, Zorica Nedovic-Budic, and Armando Carbonell. Cambridge, MA: Lincoln Institute of Land Policy.

Land Use Law Center, Pace University School of Law. 2007. "Local Land use Authority in Washington State.” Accessed May 30, 2016. http://www.horsleywitten.com/evergreen/images/Module-7-report.pdf.

League of Women Voters of Washington. 2006. "The Growth Management Act of Washington State: Successes and Challenges.” Accessed May 30, 2016. http://www.lwvwa.org/pdfs/studies/GMA_study.pdf. 
Lewis, Rebecca, and Gerrit-Jan Knaap. 2012. Institutional Structures for State Growth Management: An Examination of State Development Plans. State and Local Government Review 44(1): 33-44.

Lewis, Rebecca, Gerrit-Jan Knaap, and Jungyul Sohn. 2009. Managing Growth with Priority Funding Areas: A Good Idea Whose Time Has Yet to Come. Journal of the American Planning Association 75(4): 457-478.

Maryland Department of Environment. 2013. “Maryland's Greenhouse Gas Reduction Act Plan.” Accessed May 28, 2016. http://climatechange.maryland.gov/wpcontent/uploads/sites/16/2014/12/mde_ggrp_report11.pdf.

_. 2016. "Maryland Commission on Climate Change Update to the Governor and General Assembly.” Accessed May 28, 2016. http://www.mde.state.md.us/programs/Air/ClimateChange/Documents/2010\%20November\% 20Report.PDF.

Maryland Department of Planning. 2011. PlanMaryland. Baltimore, MD: Maryland Department of Planning.

Maryland Department of Transportation. 2014a. 2014 Annual Attainment Report: Implementing the Maryland Transportation Plan and Consolidated Transportation Program. Hanover, MD: Maryland Department of Transportation.

—. 2014b. 2035 Maryland Transportation Plan. Hanover, MD: Maryland Department of Transportation.

Mazmanian, Daniel, and Paul Sabatier. 1989.Implementation and Public Policy: With a New Postscript. Lanham, MD: University Press of America.

McDonald, Noreen. 2015. “Are Millennials Really the ‘Go-Nowhere’ Generation?” Journal of the American Planning Association 81(2): 90-103.

Melillo, Jerry M., Terese (T.C.) Richmond, and Gary W. Yohe, eds. 2014. Climate Change Impacts in the United States: The Third National Climate Assessment. U.S. Global Change Research Program. Washington, DC: U.S. Global Change Research Program, 841. Accessed May 28, 2016. http://s3.amazonaws.com/nca2014/high/NCA3_Climate_Change_Impacts_in_the_United\%2 0States_HighRes.pdf.

Michele, L. 2016. “Target and Goal Setting.” Accessed May 28, 2016. http://policyinmotion.com/state-transclimate-policy/transclimate-policy/target-and-goalsetting/.

Metro. 2014. “Climate Smart Strategy for the Portland metropolitan region.” Accessed May 28, 2016. http://www.oregonmetro.gov/climate-smart-strategy. 
Municipal Research and Services Center. 2016. “Comprehensive Planning/Growth Management.” Accessed May 30, 2016. http://mrsc.org/Home/Explore-

Topics/Planning/General-Planning-and-Growth-Management/Comprehensive-PlanningGrowth-Management.aspx.

National Research Council. 2009. Driving and the Built Environment: The Effects of Compact Development on Motorized Travel, Energy Use, and $\mathrm{CO}_{2}$ Emissions. Washington, DC: Transportation Research Board. Accessed May 31, 2016. http://onlinepubs.trb.org/Onlinepubs/sr/sr298.pdf.

Noland, Robert B., and Cynthia Burbank. 2012. "Implementing Climate Change Policies: State and Local Innovations to Mitigate and Adapt to Climate Change.” TR News 281 (JulyAugust): $3-4$.

Oregon Administrative Rule (OAR) 660-012. “Transportation Planning.” Accessed May 28, 2016. http://arcweb.sos.state.or.us/pages/rules/oars_600/oar_660/660_012.html.

Oregon Administrative Rule (OAR) 660-044. "Metropolitan Greenhouse Gas Reduction Targets.” Accessed May 28, 2016. http://arcweb.sos.state.or.us/pages/rules/oars_600/oar_660/660_044.html.

Oregon Departments of Environmental Quality, Energy, and Transportation. 2013. “Oregon’s Greenhouse Gas Emissions Through 2010: In-Boundary, Consumption-Based and Expanded Transportation Sector Inventories.” Accessed May 28, 2016. http://www.oregon.gov/deq/AQ/Documents/OregonGHGinventory07_17_13FINAL.pdf.

Oregon Department of Transportation. 2013. “Oregon Statewide Transportation Strategy: A 2050 Vision for Greenhouse Gas Emissions Reduction.” Accessed May 28, 2016. http://www.oregon.gov/ODOT/TD/OSTI/docs/STS/Oregon_Statewide_Transportation_Strat egy.pdf.

_. 2016. “Oregon Transportation Commission.” Accessed May 30, 2016. http://www.oregon.gov/odot/comm/pages/otc_main.aspx.

Oregon Global Warming Commission. 2010. “Roadmap to 2020.” Accessed May 28, 2016. http://www.keeporegoncool.org/content/roadmap-2020.

—. 2013. "Report to the Legislature.” Accessed May 28, 2016. http://www.keeporegoncool.org/sites/default/files/ogwc-standarddocuments/OGWC_2013_Rpt_Leg.pdf.

Oregon Secretary of State. 2015. “Oregon’s Executive Branch.” In Oregon Blue Book. Accessed May 30, 2016. http://bluebook.state.or.us/state/executive/executivehome.htm.

Oregon Task Force on Global Warming. (1990). Report to the Governor and Legislature. Accessed May 31, 2016. http://www.oregon.gov/energy/gblwrm/docs/1990_Oregon_Taskforce_Report_on_Global_W arming.pdf. 
Oregon Transportation Commission. 2006. “Oregon Transportation Plan.” Accessed May 28, 2016. http://www.oregon.gov/ODOT/TD/TP/pages/otp.aspx.

Pollak, Melissa, Bryn Meyer, and Elizabeth Wilson. 2011. Reducing Greenhouse Gas Emissions: Lessons from state climate action plans. Energy Policy 39: 5429-5439.

Puget Sound Regional Council. 2010. "Transportation 2040: toward a sustainable transportation system.” Accessed May 28, 2016. http://www.psrc.org/transportation/t2040/t2040-pubs/finaldraft-transportation-2040.

Rabe, Barry. 2004. Statehouse and Greenhouse: The Emerging Politics of American Climate Change. Washington, DC: The Brookings Institution.

- 2008. States on Steroids: "The Intergovernmental Odyssey of American Climate Policy.” Review of Policy Research 25(2): 105-128.

Settle, Richard, and Charles G. Gavigan. 1993. "The Growth Management Revolution in Washington: Past, Present, and Future,” University of Puget Sound Law Review 16: 867-948.

Smith, Thomas B. 1973. “The policy implementation process.” Policy Sciences 4(2):197- 209.

Turner, Colleen R., James A. Frazier, and Robert G. Kaiser. 2009. "How Will State Transportation Agencies Handle the Issue of Climate Change: A Case Study from the State of Maryland.” Paper presented at The Transportation Land Use, Planning, and Air Quality Conference, Denver, CO, July 28-29.

U.S. Census Bureau. 2012. Statistical Abstract of the United States: 2012. Accessed May 30, 2016. http://www.census.gov/prod/2011pubs/12statab/pop.pdf.

2014. Annual Estimates of the Resident Population: April 1, 2010 to July 1, 2014. Accessed May 28, 2016. http://www.census.gov/popest/data/datasets.html.

_ 2015. State Totals: Vintage 2015. Accessed May 28, 2016. http://www.census.gov/popest/data/state/totals/2015/index.html.

—. 2016. Accessed May 28, 2016. http://www.census.gov/popclock/.

U.S. Department of State. 2014. United States Climate Action Report 2014, Chap. 5: Projected Greenhouse Gas Emissions. Accessed May 28, 2016. http://www.state.gov/e/oes/rls/rpts/car6/index.htm.

U.S. Energy Information Administration. 2015. Energy-Related Carbon Dioxide Emissions at the State Level, 2000-2013. Accessed May 31, 2016. http://www.eia.gov/environment/emissions/state/analysis/.

2016a. "Inventory of U.S. Greenhouse Gas Emissions and Sinks: 1990-2014.” Accessed May 28, 2016. http://www3.epa.gov/climatechange/Downloads/ghgemissions/US-GHGInventory-2014-Main-Text.pdf. 
_. 2016b. "State Action Framework.” Accessed May 28, 2016.

http://www.epa.gov/statelocalclimate/state-climate-action-framework.

U.S. Federal Highway Administration. 2015. "U.S. Driving Nears 1 Trillion Miles in First Four Months of 2015.” Accessed May 28, 2016.

http://www.fhwa.dot.gov/pressroom/fhwa1546.cfm.

—. 2016a. "Transportation Performance Measurement.” Accessed May 30, 2016. http://www.fhwa.dot.gov/tpm/.

_ 2016b. "FHWA Publishes Performance Management Final Rules and NPRMs Required by MAP-21.” Accessed May 30, 2016. http://www.fhwa.dot.gov/tpm/rule.cfm.

Washington State Court of Appeals. 2013. "Cascade Bicycle Club v. Puget Sound Regional Council.” Accessed May 28, 2016. http://www.courts.wa.gov/opinions/pdf/675494.pdf.

Washington State Department of Commerce. 2008. "Meeting the Growth Management Challenge in Growing Communities: The Washington State Growth Management Act Effectiveness Report.” Accessed May 30, 2016. http://www.commerce.wa.gov/Documents/GMS-Effectiveness-GMA-Study-Main-ReportInfrastructure.pdf.

— 2009. “A Short Course On Local Planning: Resource Guide.” Accessed May 30, 2016. http://www.commerce.wa.gov/Documents/GMS-Short-Course-Guidebook-5-1.pdf.

Washington State Department of Ecology. 2014. "Washington State Greenhouse Gas Emissions Inventory 2010-2011.” Accessed May 28, 2016. https://fortress.wa.gov/ecy/publications/documents/1402024.pdf.

Washington State Departments of Ecology and Commerce. 2008. “Growing Washington's Economy in a Carbon-Constrained World A Comprehensive Plan to Address the Challenges and Opportunities of Climate Change.” Accessed May 28, 2016. https://fortress.wa.gov/ecy/publications/documents/0801025.pdf.

Washington State Department of Transportation. 2014. "Results WSDOT: Moving Washington Forward.” Accessed May 30, 2016. http://www.wsdot.wa.gov/Secretary/ResultsWSDOT.htm.

Washington State Legislature. 2016. "Washington State Elected Officials.” Accessed May 30, 2016. http://leg.wa.gov/legislature/Pages/ElectedOfficials.aspx.

Washington State Transportation Commission. 2015. Washington Transportation Plan 2035: Policy Plan. Accessed May 28, 2016. http://wtp2035.com.

Wassmer, Robert. 2006. "The influence of local urban containment policies and statewide growth management on the size of United States urban areas.” Journal of Regional Science 46: 25-65. 
Weitz, Jerry. 1999. "From quiet revolution to smart growth: State growth management programs, 1960 to 1999." Journal of Planning Literature 14: 266-337.

West Coast Governors' Global Warming Initiative. 2004. "Staff Recommendations to the Governors.” Accessed May 28, 2016. http://www.oregon.gov/energy/GBLWRM/docs/WCGGWINov04Report.pdf.

Western Climate Initiative. 2008. "Design Recommendations for the WCI Regional Cap-andTrade Program.” Accessed May 28, 2016. http://www.ecy.wa.gov/climatechange/WCIdocs/092308WCI_DesignRecommendations_full .pdf.

Wheeler, Stephen M. 2008. "State and Municipal Climate Change Plans: The First Generation.” Journal of the American Planning Association 74(4): 481-496.

Welch, Timothy F. 2013. Climate Action Plans_Fact or Fiction? Evidence from Maryland. College Park, MD: University of Maryland Dissertation. 


\section{APPENDIX A: SAMPLE INTERVIEW GUIDE}

Before we get started, we'd like to ask you to briefly describe the mission and charge of your organization/agency and your role in it. We will ask about the role of your agency as it specifically relates to climate change/transportation and land use later in the interview. (What does your agency do? What is your role within the agency?)

Now we would like to ask you some questions about your involvement in climate change, transportation and/or land use planning in Maryland. We will ask you about goals, efforts and results related to reducing GHG from transportation. At the end we ask some synthesis questions about the overall approach.

1. Could you briefly describe the role of your agency in reducing GHG from transportation?
a. Goals?
b. Efforts?
c. Results?

\section{A. Goals [10 minutes]}

[The next questions that we would like to ask relate to targets set by state agencies. As used here, a goal is a quantitative (or qualitative) statement to reduce GHG emissions linked to climate change or do achieve other outcomes directly linked to doing so.]

2. The Maryland Legislature passed the Greenhouse Gas Reduction Act, adopting a statutory target to reduce GHG 25\% of 2006 levels by 2020 and 90\% of 2006 levels by 2050. The GGRAP further identifies industry-specific targets. Was your organization involved in establishing sector specific targets?

a. How were these sector-specific targets established (especially related to transportation and land use?)

b. What is the role of your agency in setting and reaching these targets?

3. Who is responsible for reaching the sector-specific targets set by the GGRAP?

a. What is the timeline for implementation?

b. Are there accountability mechanisms in place to ensure targets are met? 


\section{B. Efforts [20 minutes]}

[We will now move on from our questions about goals to efforts. As used here, an effort is a law, resolution, agreement, executive order, regulation, plan, policy, strategy, study, report, public investment, incentive, tax, fee, educational program, or other public sector effort that is intended, directly or indirectly, to result in some reduction of GHG emissions, especially from the transportation sector.]

4. Briefly describe the efforts that is taking to reduce GHG from transportation or land use or supporting those efforts?

a. What are the key strategies for reducing greenhouse gas emissions from transportation within Maryland?

b. How were these key strategies selected?

c. Who was involved in selecting these strategies?

d. How are funding decisions made to implement the plans?

e. Was selection based on existing programs and plans or new policies?

5. Can you discuss role in the development in the development of these plans: PlanMaryland, Maryland Transportation Plan, and the Greenhouse Gas Reduction Act Plan?

a. What are the key strategies within each of these plans?

b. Within GGRAP, could you discuss the role of "innovative initiatives?”

6. What specific legislation is your agency is aware of, that if implemented, could help Maryland reach its GHG targets?

7. How are you involved with the Maryland Commission on Climate Change?

8. Can you discuss what agencies or organizations your agency collaborates with in efforts to achieve statewide GHG reduction goals?

a. How do you coordinate your role with other agencies or nongovernmental organizations?

b. How do you coordinate with MPOs and local governments?

c. How do you coordinate resources?

d. How do you coordinate activities and programs? 


\section{Results [10 minutes]}

[Now we'd like to move from talking about efforts to talking about statewide results that have stemmed from the efforts you just described. As used here, a result is a measurable change in GHG emissions, or in a closely related quantity, as well as efforts to monitor, report, and respond to such measurements.]

9. How do you measure effectiveness of strategies embedded in PlanMaryland and the GGRAP?

a. Can you describe the mechanisms in place to ensure accountability to goals?

b. Are there other agencies or external organizations involved in tracking progress and ensuring accountability?

10. How is Maryland measuring progress towards meeting GHG goals, especially in the transportation sector? What is your role in greenhouse gas inventories and the 2015 report to the legislature?

a. What is your agency's role in monitoring progress?

b. What is the role of other agencies or organizations?

11. Regardless of how it's being measured, in your opinion, how successful has Maryland been in its progress towards reducing GHG emissions in the transportation sector?

a. Why?/Please explain

12. How does the state adjust policies and plans based on information acquired from monitoring?

13. Who is holding Maryland accountable to reducing GHG?

a. Who is holding the MPOs accountable for reaching targets?

b. How is the state held accountable for meeting these goals?

\section{Synthesis}

14. Reflecting on your organization's plans and strategies in the context of state GHG reduction targets, how does the state transportation plan (MTP), climate action plans (GGRAP) and state land use planning program (PlanMaryland) work together to achieve these targets?

a. Do you see effective integration of transportation and land use planning, in particular, to reduce GHG from transportation?

b. Statewide?

c. Regional/local? 
15. What do you consider to be the obstacles to reducing greenhouse gas emissions from the transportation sector in Maryland?
a. Technical? (vehicle technology)
b. Procedural? (working with other agencies)
c. Financial? (lack of funding to do things we need to do-transit)
d. Political?

16. What are the strengths and weaknesses of Maryland's overall approach to reducing GHG emissions, specifically in the transportation sector?

17. Maryland is seen as a leader in climate change legislation. One of the goals of this study is to identify best practices. What recommendations would you offer to other states attempting to reduce greenhouse gas emissions from transportation?

18. Are there other people you recommend we interview?

a. Are there any user groups, nonprofits or advocacy organizations that have been involved
in the climate change planning that you would recommend for participation for interviews?

19. Is there anything else you would like to add that we have not covered?

20. We would like to come back to the written summary we provided. Have you had the chance to review it?

a. Is the information that we described accurate?

b. If not, can you tell us what information is incorrect? If there isn't time now, we'd welcome you written comments via email.

c. Is there any key information that we are missing in the summary document? 


\section{APPENDIX B: LIST OF STAKEHOLDERS INTERVIEWED}

Researchers conducted semi-structured interviews with the following stakeholders.

\section{B.1 CALIFORNIA}

1. California Air Resources Board (CARB)

1. California Council of Governments (CalCOG)

2. California Office of Planning and Research (OPR)

3. California State Transportation Agency (CalSTA)

4. California Strategic Growth Council (SGC)

5. California Dept. of Transportation (Caltrans)

6. ClimatePlan

7. League of California Cities

8. Natural Resources Defense Council (NRDC)

9. Sacramento Area Council of Governments (SACOG)

10. San Joaquin Council of Governments (SJCOG)

11. Southern California Area Governments (SCAG)

\section{B.2 MARYLAND}

1. Baltimore Metropolitan Council

2. Georgetown Climate Center

3. Maryland Dept. of Environment (MDE) $(\times 2)$

4. Maryland Dept. of Planning (MDP)

5. Maryland Dept. of Transportation (MDOT) $(\times 2)$

6. Maryland Sustainable Growth Commission

7. National Center for Smart Growth Research and Education

8. Town Creek Foundation

\section{B.3 OREGON}

1. 1000 Friends of Oregon

2. Corvallis Area MPO

3. Metro $(\times 2)$

4. Oregon Dept. of Environmental Quality (DEQ)

5. Oregon Dept. of Land Conservation and Development (DLCD)

6. Oregon Dept. of Transportation (ODOT)

7. Oregon Environmental Council (OEC)

8. Oregon Global Warming Commission (OGWC)

9. Oregon Governor's Office $(\times 2)$

10. Transportation for America 


\section{B.4 WASHINGTON}

1. Futurewise

2. Puget Sound Regional Council (PSRC)

3. Transportation Choices Coalition

4. Washington State Dept. of Commerce $(\times 2)$

5. Washington State Dept. of Ecology

6. Washington State Dept. of Transportation (WSDOT) $(\times 2)$

7. Washington State Governor's Office $(\times 2)$

8. Whatcom Council of Governments 
Transportation Research and Education Center

Portland State University

1900 S.W. Fourth Ave., Suite 175

Portland, OR 97201 